
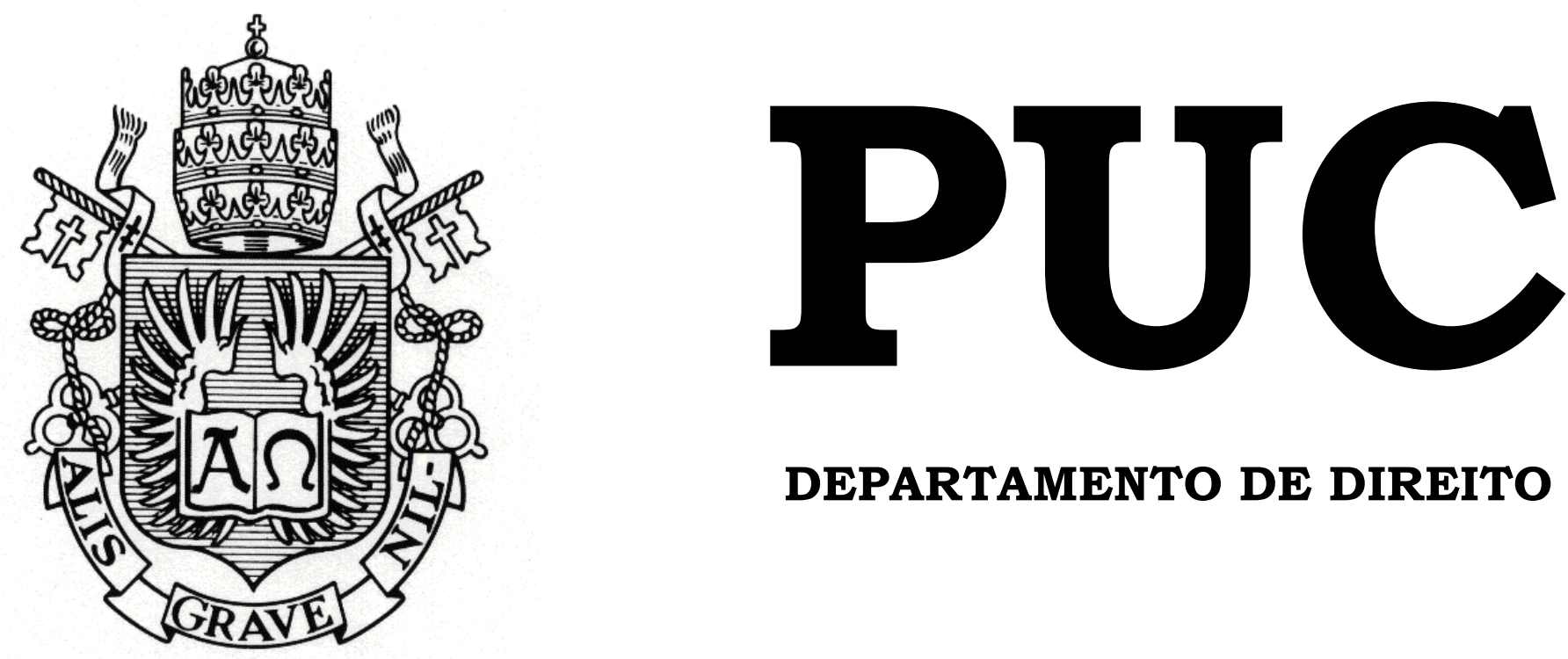

DEPARTAMENTO DE DIREITO

\title{
CONTRAPARTES CENTRAIS NOS MERCADOS DE DERIVATIVOS
}

por

MARIANNO CARNEIRO DA CUNHA

ORIENTADOR: Julian Fonseca Peña Chediak

2012.2

PONTIFÍCIA UNIVERSIDADE CATÓLICA DO RIO DE JANEIRO RUA MARQUÊS DE SÃO VICENTE, 225 - CEP 22453-900 RIO DE JANEIRO - BRASIL 


\section{CONTRAPARTES CENTRAIS NOS MERCADOS DE DERIVATIVOS}

por

\section{MARIANNO CARNEIRO DA CUNHA}

Monografia

apresentada

ao

Departamento de Direito da Pontifícia Universidade Católica do Rio de Janeiro (PUC-Rio) como requisito parcial para obtenção do título de Bacharel em Direito.

Orientador: Julian Fonseca Peña Chediak 
Aos meus pais, Tito e Angela ... 


\section{RESUMO}

Os mercados de derivativos são importantes mecanismos de gerenciamento de riscos empresariais e seu desenvolvimento nos últimos anos demonstra a relevância que adquiriram nos mercados financeiros e na economia mundial. Entretanto, os elevados riscos inerentes a esses instrumentos indicam a necessidade de regulação e supervisão adequadas, notadamente em relação às estruturas necessárias ao funcionamento desses mercados. As contrapartes centrais se inserem na tendência internacional de aprimoramento das estruturas dos mercados de derivativos e sua compreensão é fundamental para a obtenção de um desenvolvimento eficiente e responsável. O presente trabalho visa descrever o funcionamento e as principais diretrizes aplicáveis às contrapartes centrais em mercados de derivativos, abordando seus aspectos jurídicos relevantes.

\section{PALAVRAS-CHAVE}

Contrapartes Centrais - Clearings - Compensação e Liquidação - Sistemas de Pagamentos - Derivativos - Contratos a Termo - Contratos Futuros Opções - Swaps - Margem - Liquidação Compulsória 


\section{SUMÁRIO}

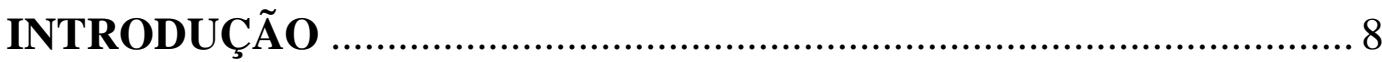

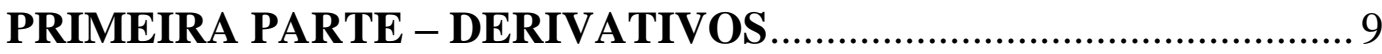

Capítulo I - Origens, Conceitos e Características Fundamentais ......... 9

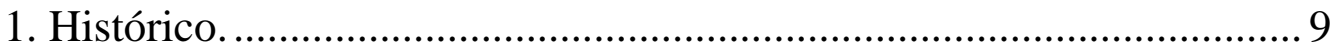

2. Mas afinal, o que são Derivativos? ........................................... 16

2.1. Conceitos Tradicionais ........................................................ 16

2.2. Tratamento Legal.......................................................... 17

2.2.1. Investimento, Jogo ou Aposta? .................................... 18

2.2.2. Legislação Falimentar ................................................... 20

2.2.3. Derivativos como Valores Mobiliários ............................. 20

2.3. Abordagem Regulamentar.................................................. 24

2.4. Perspectiva Jurisprudencial e Doutrinária ............................. 25

2.5. Um Dilema Conceitual ........................................................ 26

Capítulo II - Funções Econômicas e Agentes de Mercado ................... 27

3. As Funções Econômicas dos Derivativos ....................................... 27

4. Um "Negócio de Risco" .......................................................... 28

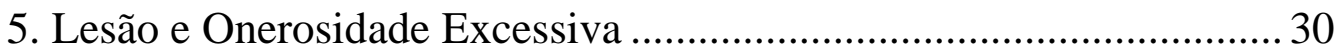

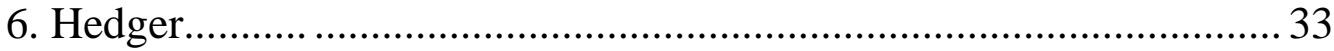

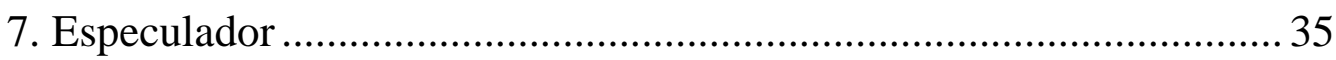

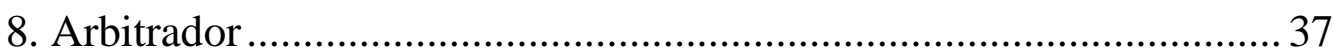

Capítulo III - Mercados e Modalidades de Negociação ....................... 38

9. Autorregulação e Estruturas Contratuais ........................................ 38

10. Negociações em Mercados de Bolsa e Balcão............................... 39 
11. Contratos a Termo

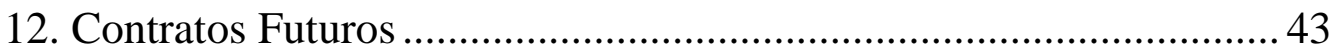

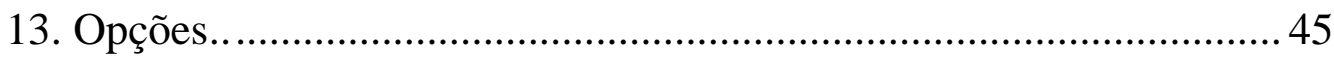

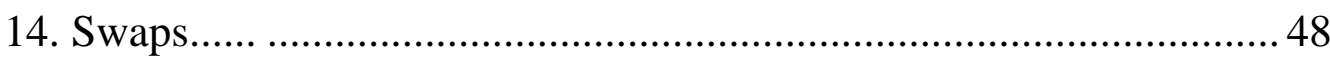

15. Os Mercados de Derivativos no Brasil ................................................52

SEGUNDA PARTE - NOÇÕES FUNDAMENTAIS DE SISTEMAS

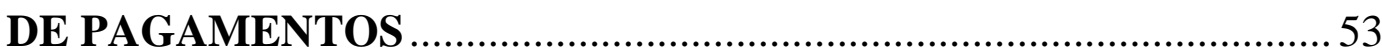

Capítulo IV - Os Sistemas de Pagamentos e sua Importância na

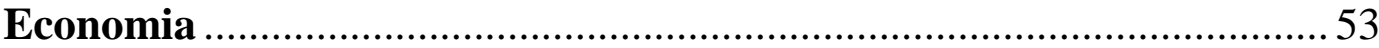

16. Economia de Mercado e Moeda............................................................53

17. O Papel dos Sistemas de Pagamentos na Economia em Geral .......... 56

18. O Papel dos Sistemas de Pagamentos na Estabilidade Financeira e na Política Monetária..................................................... 58

19. Recomendações Internacionais para Sistemas de Pagamentos..........59

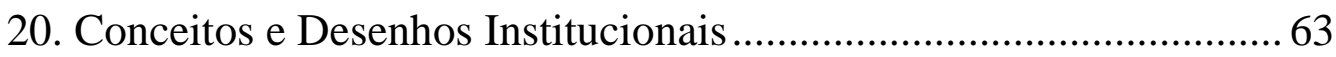

20.1. O Processo de Compensação e Liquidação ................................. 65

20.1.1. Transmissão de Instrução de Pagamento ............................ 65

20.1.2. Compensação (Clearance ou Clearing) ............................. 65

20.1.2.1. Compensação pelo Valor Bruto ..................................... 66

20.1.2.2. Compensação pelo Valor Líquido (Netting).............. 66

20.1.2.2.1. Compensação pelo Valor Líquido Bilateral ....... 67

20.1.2.2.2. Compensação pelo Valor Líquido Multilateral . 68

20.1.2.2.3. Acordos de Compensação na Falência................ 68

20.1.3. Liquidação (Settlement) .................................................... 72

20.1.3.1. Liquidação em Tempo Real e Diferida....................... 72

20.1.3.2. Liquidação Provisória e Final ....................................... 73

20.2. Desenhos Institucionais Típicos (RGTS e DNS) ...................... 74 


\section{TERCEIRA PARTE - CONTRAPARTES CENTRAIS NOS}

MERCADOS DE DERIVATIVOS ...................................................... 76

Capítulo V - Sistema de Pagamentos Brasileiro ……………………..... 76

Capítulo VI - Clearing de Derivativos .................................................... 79

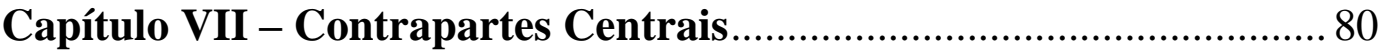

21. Conceito e Importância Econômica ………………………………..... 80

22. Regras de Acesso e Cadeia de Responsabilidades .............................. 83

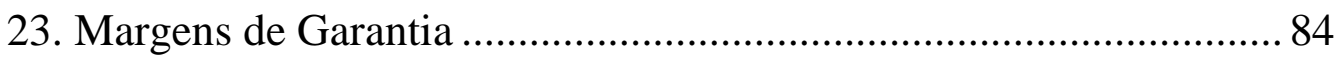

23.1. Conceito e Natureza Jurídica ....................................................... 84

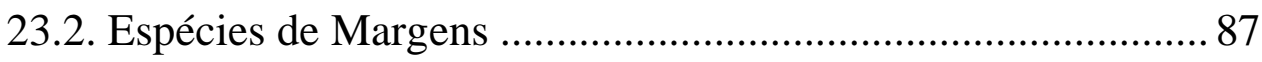

23.3. Ajuste Diário e Encerramento de Posições ................................ 89

23.4. Colateralização de Derivativos de Balcão ……………………... 91

24. Liquidação Compulsória ...................................................................... 93

25. Fundos Garantidores e Patrimônio Especial .......................................... 97

26. Contrapartes Centrais nos Mercados Brasileiros de Derivativos...... 98

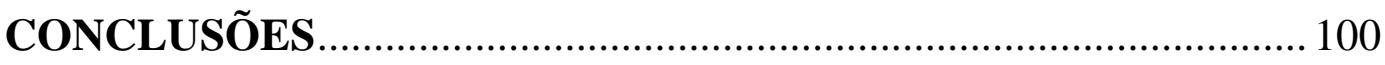

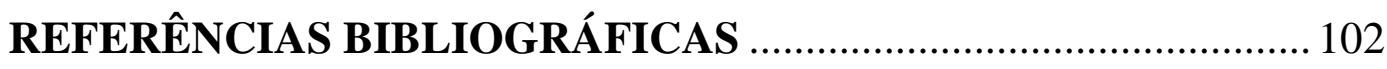




\section{Lista de Siglas}

BACEN - Banco Central do Brasil

BIS - Bank for International Settlements

CFTC - Commodity Futures Trading Commission

CMN - Conselho Monetário Nacional

CVM - Comissão de Valores Mobiliários

IOSCO - International Organization of Securities Commissions

ISDA - International Swaps and Derivatives Association

SEC - Securities and Exchange Commission

BM\&FBovespa - BM\&FBovespa S.A. - Bolsa de Valores, Mercadorias e Futuros

CETIP - CETIP S.A. - Mercados Organizados 


\section{INTRODUÇÃO}

Atualmente, os mercados de derivativos desempenham papel fundamental na administração de riscos empresariais e seu desenvolvimento tende a demandar, cada vez mais, um aprimoramento dos mecanismos de proteção de seus participantes.

As contrapartes centrais são compreendidas como uma das principais estruturas destinadas a garantir a solidez dos mercados de derivativos e, por isso, mereceram atenção especial dos reguladores internacionais após a crise de 2008, em que diversos agentes econômicos negociavam derivativos de balcão sem a necessária cobertura dos riscos envolvidos nessas operações. Nesse sentido, a Cúpula do G-20 traçou como diretriz internacional a submissão de todos os derivativos de balcão padronizados a sistemas de compensação e liquidação que atuem como contrapartes centrais. ${ }^{1}$

Assim, o presente estudo pretende detalhar o funcionamento, a importância e as principais características das contrapartes centrais que atuam nos mercados de derivativos, destacando especialmente os contornos jurídicos dessas estruturas.

Para tanto, a Primeira Parte deste estudo é dedicada à analise dos mercados de derivativos em seus aspectos econômicos e jurídicos. A exposição constituirá o plano de fundo para a compreensão das contrapartes centrais.

Já na Segunda Parte, as noções fundamentais sobre sistemas de pagamentos serão analisadas com vistas a elucidar a importância das transferências de recursos nas economias da atualidade e os principais mecanismos envolvidos nos processos compensação e liquidação de obrigações financeiras.

\footnotetext{
${ }^{1}$ Item 25 da Declaração de Toronto de junho de 2010, emitida pela Cúpula do G-20. Disponível em <http://www.canadainternational.gc.ca/g20/summit-sommet/2010/toronto-declaration-toronto. aspx?lang=eng\&view=d $>$. Acesso em 25 out. 2012.
} 
A partir dos subsídios fornecidos pela Primeira e Segunda Partes, o estudo focará no tema das contrapartes centrais nos mercados de derivativos, abordando suas características fundamentais, além das principais controvérsias jurídicas existentes - o que constituirá a Terceira Parte.

\section{PRIMEIRA PARTE - DERIVATIVOS}

\section{Capítulo I - Origens, Conceitos e Características}

\section{Fundamentais}

\section{Histórico}

Os derivativos são normalmente apresentados como instrumentos que se aprimoraram no final do século XX, sobretudo entre as décadas de 1970 e 1980. No entanto, podemos observar que sua lógica esteve presente em nossa sociedade desde tempos mais remotos. Nas palavras de Peter Bernstein, "Derivatives go back so far in time that they have no identifiable inventors: no Cardano, Bernoulli, Graunt, or Gauss". ${ }^{2}$

A partir da invenção da escrita na Mesopotâmia, observamos as primeiras manifestações dos derivativos inscritas em tábuas de barro, que registravam compromissos entre particulares, como demonstra o exemplo abaixo:

\footnotetext{
"The following tablet, which is from $1809 \mathrm{BC}$, shows that a Mesopotamian merchant borrowed silver, promising to repay it with sesame seeds 'according to the going rate' after six months. He may have used the silver to finance a trading mission to the Indus Valley to obtain sesame seeds. This contract combines a silver loan with a forward sale of sesame seeds." ${ }^{3}$
}

\footnotetext{
${ }^{2}$ BERNSTEIN, Peter L. Against the gods: The remarkable story of risk. New York: J. Wiley, 1996. p. 304

${ }^{3}$ WEBER, Ernst Juerg. A Short History of Derivative Security Markets (pp. 5-6). Disponível em SSRN <http://ssrn.com/abstract=1141689 >. Acesso em 07 de abril de 2012.
} 
Um caso interessante também é atribuído ao filósofo Tales de Mileto. Utilizando-se de seus conhecimentos, o filósofo projetou uma safra recorde de azeitonas em sua cidade, o que o levou a comprar a opção de usar com exclusividade os moinhos que as processavam. Posteriormente, com a verificação da safra esperada, o filósofo renunciou a esse direito em troca de uma grande remuneração, demonstrando, nas palavras de Aristóteles, narrador da história, que os filósofos só não são ricos porque sua ambição é de outra ordem. ${ }^{4}$

Também merecem destaque na história dos derivativos, as negociações de arroz a futuro no Japão durante o século XVIII, bem como as opções sobre tulipas comercializadas na Holanda durante o século XVII. ${ }^{5}$

No século XIX, comerciantes de produtos agrícolas (commodities) da cidade de Chicago nos Estados Unidos organizaram a denominada Chicago Board of Trade (CBOT). Além de propiciar um intenso ambiente de negociação, essa entidade também se tornou referência no armazenamento e distribuição de commodities no Meio-Oeste dos Estados Unidos. Porém, a sazonalidade característica da produção agrícola gerava, por diversas vezes, a superlotação ou a subutilização de estoques, assim como bruscas variações de preços.

O problema foi contornado com a criação dos chamados "to-arrive contracts", em que os agentes estabeleciam um preço fixo para a entrega da mercadoria em uma data futura. Dessa forma, os agentes neutralizavam os riscos da flutuação sazonal dos preços e não precisavam remeter suas mercadorias imediatamente para os estoques de Chicago. ${ }^{6}$

\footnotetext{
${ }^{4}$ RUSSEL, Bertrand. History of Western Philosophy. Londres: Routledge, sem data, p. 46 apud. NETO, Eduardo Salomão. Direito Bancário. $1^{\text {a }}$ Ed. São Paulo: Editora Atlas, 2005. p. 324.

${ }^{5}$ Cf. EIZIRIK, Nelson. Aspectos jurídicos dos mercados futuros. Revista de Direito Mercantil. São Paulo: Revista dos Tribunais, 1991, vol. 81, p. 22; e SZTAJN, Rachel. Sobre a natureza jurídica das opções negociadas em bolsas. Revista de Direito Mercantil. São Paulo: Malheiros, 1997, vol. 105 , p. 55.

${ }^{6}$ Cf. CHANCE, Don M. A Brief History of Derivatives. In: CHANCE, Don M. Essays in Derivatives: Risk-Transfer Tools and Topics Made Easy. $2^{\text {nd }}$ Ed. New Jersey: John Wiley \& Sons, 2008. p. 7.
} 
Gradualmente, essas operações foram se aprimorando com novos mecanismos de garantia e catalisação das trocas, de maneira que as mais antigas contratações a termo foram ganhando a forma dos chamados contratos futuros.

Seguindo essa tendência, a Chicago Butter and Egg Board foi fundada em 1898 por um grupo de produtores. Com a entrada dos Estados Unidos na $1^{\mathrm{a}}$ Guerra Mundial, a U.S. Food Administration suspendeu a negociação de contratos de manteiga e ovos, levando os participantes desse mercado a transformar a Chicago Butter and Egg Board na Chicago Mercantile Exchange (CME), na qual uma variedade de produtos agrícolas era negociada a futuro. Nos anos seguintes, observamos diversas leis tratando dos derivativos, dentre as quais se destaca o Commodity Exchange Act, editado em 1936, que estendeu a regulação federal existente à época a uma série de commodities, como algodão, manteiga e arroz. ${ }^{7}$

Na década de 1970, os desenvolvimentos acadêmicos na área de finanças permitiram uma incrível sofisticação dos derivativos, na medida em que forneceram o suporte teórico adequado a essas operações. Um marco desse período foi a teoria de precificação de opções (conhecida como Black-Scholes Model), elaborada conjuntamente pelos acadêmicos Robert Merton, da Harvard Business School, e Myron Scholes e Fisher Black, da Universidade de Chicago. ${ }^{8}$ Nesse momento, também foi criada a Commodity Futures Trading Commission (" $\underline{\mathrm{CFTC}}$ "), agência encarregada de regular todos os mercados futuros nos Estados Unidos.

A década de 1970 também foi marcada pela atuação de Richard Nixon, então presidente dos Estados Unidos, contra o sistema de câmbio

\footnotetext{
${ }^{7}$ Cf. COMMISSION, Commodity Futures Trading. History of the CFTC. Disponível em <http://www.cftc.gov/About/HistoryoftheCFTC/index.htm>. Acesso em 08 de abril de 2012; e GROUP, CME. From Water Street to the World. CME Group Magazine, Summer 2007. Disponível em <http://www.cmegroup.com/company/history/magazine/Summer2007/FromWater StreetToTheWorld.html>. Acesso em 08 de abril de 2012.

${ }^{8}$ Cf. GOLDBERG, Daniel Krepel. A Lei 10.303, de 2001, e a inclusão dos derivativos no rol dos valores mobiliários. Revista de Direito Mercantil. São Paulo: Malheiros, 2003, vol. 129, p. 76.
} 
fixo estabelecido em Bretton Woods, resultando na desvinculação do dólar norte-americano ao ouro e, considerando que as demais moedas estavam indexadas ao valor do dólar, observou-se a consequente abertura das economias mundiais para taxas de câmbio variáveis. Nesse cenário de incerteza, surgiram discussões sobre a criação de um mercado de derivativos para proteção contra o risco cambial e, sob a liderança institucional de Leo Melamed e o apoio acadêmico de Milton Friedman, o CME Group inaugurou o International Monetary Market (IMM), um novo mercado destinado a suprir tal demanda por proteção cambial a partir da negociação de futuros de libras, dólares canadenses e outras moedas. ${ }^{9}$

Nascem, assim, os primeiros instrumentos futuros baseados em ativos financeiros, posteriormente conhecidos como financial futures. Em seu desenvolvimento, esses derivativos financeiros ainda passaram a incorporar outros ativos subjacentes, como taxas de juros e índices - por exemplo, em 1982, a CFTC aprovou a negociação na Kansas City Board of Trade do primeiro contrato futuro baseado em um índice de ações. ${ }^{10}$ Aliás, o próprio conceito legal de commodity presente na Seção 2 (a)(1) do Commodity Exchange Act, antes restrito à expressão "goods and articles", foi ampliado para abranger também "and all services, rights and interests in which contracts for future delivery are presently or in the future dealt in". Passou-se, então, a considerar commodity todo objeto de contrato futuro, independentemente de sua natureza. ${ }^{11}$

Os anos posteriores foram marcados por um contínuo processo de inovação financeira, seguido de movimentos regulatórios, em um mercado

\footnotetext{
${ }^{9}$ Cf. GROUP, CME. The Birth of FX Futures. Disponível em <http://www.cmegroup.com/ company/center-for-innovation/files/history of_FX.pdf >. Acesso em 05 de novembro de 2012.

${ }^{10}$ COMMISSION, Commodity Futures Trading. History of the CFTC. Disponível em <http://www.cftc.gov/About/HistoryoftheCFTC/index.htm>. Acesso em 08 de abril de 2012.

${ }^{11}$ Cf. LOBO, Carlos Augusto da Silveira. Os mercados de futuros. Revista de Direito Mercantil. São Paulo: Malheiros, 2001, vol. 124, p. 150. No mesmo sentido, manifesta-se o professor Nelson Eizirik (EIZIRIK, Nelson. Aspectos jurídicos dos mercados futuros. p. 25). Note-se que, apesar da mudança legislativa, no dia-a-dia dos mercados a noção de commodity continua associada aos produtos agropecuários (como soja, milho, café, boi gordo, etc).
} 
tradicionalmente marcado por grandes volumes, fraudes e perdas. Um dos episódios mais conhecidos envolve o Condado de Orange, na Califórnia, que enfrentou perdas com derivativos na ordem de 1,5 bilhão de dólares. ${ }^{12}$ Outro caso de grande repercussão ocorreu, quando a Sumitomo Corporation anunciou perdas de aproximadamente 2,6 bilhões de dólares no mercado de derivativos de cobre. ${ }^{13}$ Também se destaca nos anos 90 a quebra do Long Term Capital Management Fund - LCTM, um fundo administrado, entre outros, pelos prestigiados acadêmicos Robert Merton e Myron Scholes. À época, o fundo, que tinha 100 bilhões de dólares em ativos, acumulou uma exposição superior a 1 trilhão de dólares. ${ }^{14}$

Ainda nos anos 90, surgiram os derivativos de créditos como alternativa às regras limitativas de endividamento impostas às instituições financeiras. ${ }^{15}$ Já em 2000, destaca-se o acordo de cooperação entre a CFTC e a Securities and Exchange Commission ("SEC") para a supervisão conjunta dos contratos futuros sobre ações e índices de ações. Neste mesmo ano, foi promulgado o Commodity Futures Modernization Act, permitindo a flexibilização de diversas estruturas regulatórias dos mercados de derivativos. ${ }^{16} \mathrm{E}$, em 2007, a união entre a Chicago Board of Trade e a Chicago Mercantile Exchange foi oficializada, resultando na maior e mais

\footnotetext{
${ }^{12}$ KOESTER, Axel. Today, Orange County... Businessweek, 18 de dezembro de 1994. Disponível em 〈http://www.businessweek.com/stories/1994-12-18/today-orange-county-dot-dot-dot>. Acesso em 08 de abril de 2012.

${ }^{13}$ WUDUNN, Sheryl. Sumitomo Increases Size of Copper-Trade Loss to \$2.6 Billion, New York Times, 20 de setembro de 1996. Disponível em <http://www.nytimes.com/1996/09/20/business/ sumitomo-increases-size-of-copper-trade-loss-to-2.6-billion.html?src=pm>. Acesso em 08 de abril de 2012.

${ }^{14}$ Cf. GOLDBERG, Daniel Krepel. A Lei 10.303, de 2001, e a inclusão dos derivativos no rol dos valores mobiliários. p. 79.

${ }^{15} \mathrm{Cf}$. YAZBEK, Otavio. O risco de crédito e os novos instrumentos financeiros - uma análise funcional. In: WAISBERG, Ivo; e FONTES, Marcos Rolim Fernandes (Coords.). Contratos bancários. São Paulo: Quartier Latin, 2006, p. 330.

16 COMMISSION, Commodity Futures Trading. History of the CFTC. Disponível em <http://www.cftc.gov/About/HistoryoftheCFTC/index.htm>. Acesso em 08 de abril de 2012
} 
diversificada bolsa de negociação de derivativos no mundo, a CME Group Inc. ${ }^{17}$

A partir de então, o mundo assistiu ao declínio de símbolos da prosperidade econômica, em uma crise profunda, sistêmica e transnacional. Os derivativos e, mais especificamente, os denominados Collateralized Debt Obligation (“" diretamente relacionados às origens da crise surgida nos Estados Unidos. Em sua mecânica típica, os CDOs compilavam os rendimentos decorrentes de financiamentos hipotecários e os CDSs transferiam o risco de crédito para terceiros ao garantir os pagamentos em caso de inadimplência. ${ }^{18}$

A partir de operações com tais instrumentos, os bancos reduziam sua exposição ao risco, o que resultava em uma menor necessidade de capital regulatório para garantir sua solvência. Consequentemente, mais recursos estavam disponíveis para empréstimos com menores taxas de juros. A abundância de crédito na economia aumentava e a grande procura por imóveis levava à elevação dos preços. Os altos preços, por sua vez, aumentavam a demanda por crédito e os bancos, podendo transferir o risco de inadimplemento, tinham incentivos para concedê-lo, inclusive para parcela da população sem capacidade financeira de honrá-los (daí a expressão "sub-prime”). Nesse cenário, os bancos e demais agentes

${ }^{17}$ GROUP, CME. Spirit of Innovation. Disponível em <http://www.cmegroup.com/company/ history/timeline-of-achievements.html>. Acesso em 07 de abril de 2012.

${ }^{18}$ Sobre o tema, destaque-se a explicação de Robert L. McDonald: "A collateralized debt obligation (CDO) is a financial structure that repackages the cash flows from a set of assets. You create a $\mathrm{CDO}$ by pooling the returns from a set of assets and issuing financial claims to this pool. The CDO claims reapportion the returns on the asset pool. Typically, CDO claims are tranched, meaning that the different $\mathrm{CDO}$ claims have differing priorities with respect to the cash flows generated by the collateral. With a CDO, it is possible to take a group of risky bonds, for example, and create new claims, some of which are less risky than the original bonds, and others are riskier. (...) A single name credit default swap (CDS) [negrito inserido] makes a payment when a specific company (the 'single name') experiences a credit event. The buyer of the swap is the protection buyer. A corporate bondholder, for example, could use a CDS to buy protection against the credit risk of a company. The counterparty providing the credit insurance is the swap writer or protection seller. (...) Both the written CDS and the CDO bear the costs of a default. The difference between the two positions (...) is the payoff to a default-free bond. The difference between the CDO and written CDS, therefore, is that the CDO is funded, meaning that the investor pays for it fully at the outset, while the CDS is unfunded, meaning that the investor pays nothing at the outset and can have payment obligations in the future." (MCDONALD, Robert L., Derivatives markets. $2^{\text {nd }}$ Ed., Boston: Addison Wesley, 2006, pp. 853, 860-862) 
intermediários flexibilizaram suas avaliações de crédito, bem como o monitoramento da inadimplência. A regulação, por sua vez, permitia a concentração excessiva de riscos em certos agentes, bem como a contratação de CDSs em montante superior aos créditos em carteira (modalidade conhecida como "naked” ou "descoberta”).

Contudo, a sobrevalorização artificial dos imóveis chegou ao ponto de tornar inviável a sua compra, o que reduziu a procura e, consequentemente, os preços. A baixa capacidade creditícia, juntamente com a queda nos preços, deflagrou um aumento generalizado da inadimplência. Assim, a população tomadora dos empréstimos perdia suas residências em execuções hipotecárias, enquanto bancos, seguradoras e demais intermediários tinham de reconhecer imensos prejuízos decorrentes dos CDOs e CDSs em suas carteiras.

Após uma série de medidas de urgência, foi promulgada em julho de 2010 uma extensa lei de reforma do sistema financeiro norte-americano, a denominada Dodd-Frank Wall Street Reform and Consumer Protection Act ("Lei Dodd-Frank"). Além de promover uma ampla revisão das regras aplicáveis aos derivativos, essa iniciativa regulatória gerou reflexos diretos em outras regulações ao redor do mundo. ${ }^{19-20}$

Atualmente, os mercados de derivativos nos Estados Unidos são regulados principalmente pela Lei Dodd-Frank e as normas regulamentares editadas pela CFTC e SEC. A difícil tarefa dos reguladores envolve um

\footnotetext{
${ }^{19}$ No Brasil, por exemplo, a Instrução CVM no $486 / 10$ inseriu o art. 4-A na Instrução CVM no 467/08, ampliando a transparência das operações envolvendo derivativos, ao dispor que: "As entidades administradoras de mercados organizados podem, observado o disposto nos incisos I e V do $\S 3^{\circ}$ do art. $1^{\circ}$ da Lei Complementar $\mathrm{n}^{\circ} 105$, de 10 de janeiro de 2001, criar mecanismos de compartilhamento de informaç̃es sobre operacões com contratos derivativos negociados ou registrados em seus sistemas, com fins de administração de riscos pelas instituições financeiras." (grifos nossos)

${ }^{20}$ A explicação da crise foi baseada no artigo de ALMEIDA, Samy Sanches de. Crise dos derivativos: reforma Dodd-Frank e o clearing centralizado. Revista de Direito Mercantil. São Paulo: Malheiros, 2011, vol. 157, pp. 167-185.
} 
mercado de futuros da ordem de US\$37 trilhões e um mercado de swaps de

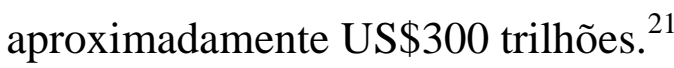

Além disso, a regulação enfrenta os desafios decorrentes de sofisticados arranjos contratuais, baseados em cálculos financeiros complexos e na mais alta tecnologia aplicada aos sistemas de negociação, como ilustrado pelo trecho abaixo:

"Trades in those contracts [metals and energies] now occur, on average, in a range of 10 milliseconds to sub-3 milliseconds depending on volatility or trading matching dynamics. And just how fast is a millisecond? Well, a blink of an eye takes about 300 to 400 milliseconds." 22

\section{Mas afinal, o que são Derivativos?}

\subsection{Conceitos Tradicionais}

Em obra clássica sobre o tema, John Hull define derivativo como um instrumento financeiro cujo valor depende (ou deriva) dos valores de outras variáveis subjacentes mais básicas. ${ }^{23}$ Sendo assim, o denominado ativo subjacente (underlying asset) seria o elemento a partir do qual se deriva o valor desse instrumento. ${ }^{24}$

\footnotetext{
${ }^{21}$ GENSLER, Gary. Chairman's Transmittal Letter. In: COMMISSION, Commodity Futures Trading. The FY 2013 President's Budget \& Performance Plan. Disponível em <http://www.cftc.gov/About/ CFTCReports/index.htm>. Acesso em 07 de abril de 2012.

${ }^{22}$ GROUP, CME. Life in the Fast Lane. Disponível em <http://www.cmegroup.com/company/ history/magazine/vol7-issue2/life-in-the-fast-lane.html>. Acesso em 07 de abril de 2012.

${ }^{23}$ HULL, John. Options, futures, and other derivatives. $6^{\text {th }}$ Ed., New Jersey: Prentice Hall, 2006, p. 1.

${ }^{24}$ A regulamentação brasileira exige que os ativos subjacentes tenham valor objetivamente verificável, conforme dispõe o art. $5^{\circ}$ da Instrução CVM n ${ }^{\circ} 467 / 08$. Sobre o tema, destaque-se a passagem do voto do Diretor-Relator Luiz Antonio de Sampaio Campos, no âmbito do Processo Administrativo CVM n. ${ }^{\circ}$ RJ 2003/0499, julgado em 28.08.2003: “A ponderação da SRE no sentido de que não há transparência nem tampouco informação pública a respeito da formação do preço do ativo subjacente, que não necessariamente é realizado em condições de mercado ou como resultado das condições gerais de funcionamento da economia também não descaracteriza o derivativo. Considero, contudo, que a política regulatória dos derivativos ofertados publicamente a investidores em geral deve, entre outros elementos, considerar o risco da opacidade do ativo subjacente." (grifos nossos).
} 
A noção de derivar é bem capturada pelo tradicional Black's Law Dictionary no verbete:

"Derivative. Coming from another; taken from something preceding; secondary. That which has not its origin in itself, but owes its existence to something foregoing. Anything obtained or deduced from another." (grifos originais) ${ }^{25}$

Observe-se, contudo, que o preço de um ativo subjacente também pode ser influenciado pelo derivativo a que está referenciado. Um bom exemplo disso é apresentado por Claude Brown, ao descrever que a negociação de contratos futuros sobre um índice de ações afeta o valor das ações integrantes desse índice sem que elas próprias sejam negociadas. Nesse caso, indaga o autor: "which product is the underlying and which is the derivative?" 26

\subsection{Tratamento Legal}

Nos Estados Unidos, a Lei Dodd-Frank apresenta um conceito extenso do que sejam “operações de derivativos" nos seguintes termos:

"the term 'derivative transaction' includes any transaction that is a contract, agreement, swap, warrant, note, or option that is based, in whole or in part, on the value of, any interest in, or any quantitative measure or the occurrence of any event relating to, one or more commodities, securities, currencies, interest or other rates, indices, or other assets." 27

Já no Brasil, a legislação optou por não conceituar o que seriam derivativos, embora seja possamos encontrar referências diretas a esses instrumentos, como indicado abaixo.

\footnotetext{
${ }^{25}$ BLACK, Henry Campbell, Black's law dictionary. $6^{\text {th }}$ Ed. Minnesota: West Publishing Co, 1990. p. 443.

${ }^{26}$ BROWN, Claude. How to Recognize a Derivative. International Financial Law Review (May 1995). London: Euromoney Institutional Investors, 1995, p. 28.

${ }^{27}$ Dodd-Frank Wall Street Reform and Consumer Protection Act (H.R. 4173), Section 610 (a)(3).
} 


\subsubsection{Investimento, Jogo ou Aposta?}

O Código Civil de 1916, em seu art. 1.479, equiparava as operações liquidadas exclusivamente por diferença ao jogo ou aposta, o que tornava suas obrigações inexigíveis (dada sua qualidade de obrigações naturais). Diante dos riscos trazidos por essa regra, os contratos passaram a prever uma obrigação alternativa de entregar o bem ou pagar a diferença. ${ }^{28}$ Tal mecanismo reconhecidamente não passava de mero expediente para contornar a equiparação legal, sendo a liquidação por diferença adotada na imensa maioria dessas contratações. ${ }^{29}$ Além disso, tal dispositivo, em tese, restringiria o objeto das operações com derivativos a bens suscetíveis de entrega física, mas simplesmente se ignorava tal problema legal. ${ }^{30}$

Durante a tramitação do Projeto de Lei no 634 de 1975, que instituiu o Código Civil de 2002, o texto original do art. 816 era mera repetição do art. 1.479 do Código Civil de 1916. Essa situação só foi, então, modificada por emenda apresentada pelo Senado Federal. Argumentou-se, à época, que o volume negociado na Bolsa de Mercadorias e Futuros era equivalente a 10 vezes o PIB nacional. ${ }^{31}$ Assim, o Novo Código Civil pareceu afastar a citada equiparação ao prever que:

\footnotetext{
“Art. 816. As disposições dos arts. 814 e 815 não se aplicam aos contratos sobre títulos de bolsa, mercadorias ou valores, em que se estipulem a liquidação exclusivamente pela diferença entre o preço ajustado e a cotação que eles tiverem no vencimento do ajuste."
}

\footnotetext{
${ }^{28}$ Cf. SZTAJN, Rachel. Regulação e o Mercado de Valores Mobiliários. Revista de Direito Mercantil. São Paulo: Malheiros, 2004, vol. 135, p. 143.

${ }^{29}$ Sobre o conceito de liquidação por diferença, vide o Item 12 (“Contratos Futuros”) deste estudo.

${ }^{30}$ Nesse sentido, COELHO, Fabio Ulhoa. Os derivativos e a desvalorização do Real em 2008 Revista de Direito Bancário e do Mercado de Capitais. São Paulo: Revista dos Tribunais, 2009, vol. 44, p. 82; e LOBO, Carlos Augusto da Silveira. Os mercados de futuros. p. 151.

${ }^{31}$ DEPUTADOS, Câmara dos. Parecer da Comissão Especial destinada a apreciar as emendas do Senado Federal ao Projeto de Lei $n^{o} 634$ de 1975. p. 289. Disponível em <www.camara.gov.br/sileg/integras/303077.doc $>$. Acesso em 20 de maio de 2012.
} 
A nova redação certamente contribuiu para uma maior segurança jurídica, ainda que não seja imune a críticas. ${ }^{32}$ Acerca do tema, destaque-se que a Suprema Corte norte-americana já havia decidido, quase um século antes, que os contratos para entrega futura seriam vinculantes (Christie Grain \& Stock Co. v. Chicago Board of Trade, 1905, 198 U.S., 236). ${ }^{33}$

Por outro lado, os derivativos também não podem ser considerados como investimentos, na medida em que não representam propriamente a detenção de um ativo (e, aliás, nem a existência de um passivo). Tais problemas em sua classificação contábil os levaram a ser considerados elementos "fora do balanço" (off-balance sheet), o que reduz a transparência das demonstrações financeiras dos agentes que atuam em seus mercados. ${ }^{34}$ Registre-se, contudo, os recentes esforços da International Accounting Standards Board - IASB em detalhar sua situação contábil, unificando o tratamento internacional dado à matéria.

\footnotetext{
${ }^{32}$ No sentido da impossibilidade de equiparação dos derivativos em geral a jogo ou a aposta, destacam-se Eduardo Salomão Neto, Luiz Alfredo Paulin e Sergio Mychkis Goldstein. Já em uma abordagem mais sutil, Otavio Yazbek ressalta que todo contrato de derivativo é um contrato diferencial e a discussão em torno da equiparação promovida pelo revogado art. 1.479 perdeu importância com o advento do Novo Código Civil. Por outro lado, Rachel Sztajn apresenta uma dura crítica à redação do dispositivo, ao afirmar que: "Ainda não resolve de vez o problema dos contratos diferenciais e, pior, não resolve problemas criados por outros derivativos que haja previsão de liquidação por diferença. Mais sério, parece, é que se contratos negociados em bolsa não serão equiparados a jogo ou aposta, a mesma regra não se estende a contratos celebrados com instituições financeiras e/ou com sua intermediação entre particulares." (NETO, Eduardo Salomão. Direito Bancário. p. 339; PAULIN, Luiz Alfredo. Das alterações introduzidas pelo novo código civil no mercado de capitais. Revista de Direito Bancário e do Mercado de Capitais. São Paulo: Revista dos Tribunais, 2003, vol. 21, p. 259; GOLDSTEIN, Sergio Mychkis. Aspectos jurídicos dos derivativos de crédito no Brasil. Revista de Direito Bancário e do Mercado de Capitais. São Paulo: Revista dos Tribunais, 2004, vol. 25, p. 63; YAZBEK, Otavio. Regulação do Mercado Financeiro e de Capitais. Rio de Janeiro: Elsevier, 2007, p. 107; e SZTAJN, Rachel. Regulação e o Mercado de Valores Mobiliários. p. 144).

${ }^{33}$ A decisão é mencionada em FILHO, Oscar Barreto. As operações a termo sobre mercadorias (“hedging”). Revista de Direito Mercantil. São Paulo: Revista dos Tribunais, 1976, vol. 29, p. 16.

${ }^{34}$ Cf. YAZBEK, Otavio. Regulação do Mercado Financeiro e de Capitais. p. 111.
} 


\subsubsection{Legislação Falimentar}

A Lei 11.101/05 também trata dos derivativos ao prever que nas coisas vendidas a termo que tenham cotação em bolsa ou mercado e cujo contrato não estipule a entrega física do bem, deverá ser prestada a diferença entre a cotação do dia do contrato e a da época da liquidação em bolsa ou mercado, ou seja, a liquidação por diferença ocorrerá normalmente no vencimento (Art. 119, inciso V). ${ }^{35}$

Essa disposição se baseia na premissa de que não há como se atribuir um valor arbitrário a pagar ou a receber no momento da falência, caso a obrigação somente tenha a apuração de seu valor em momento futuro fixado pelas partes. Nesses casos, desde que haja nexo sinalagmático entre as obrigações, admite-se a recusa de uma parte em cumprir sua obrigação quando sua contraparte sofre uma diminuição patrimonial capaz de comprometer ou tornar duvidoso o cumprimento de sua respectiva obrigação, conforme previsto no art. 477 do Código Civil. ${ }^{36}$

\subsubsection{Derivativos como Valores Mobiliários}

Por sua vez, a reforma promovida pela Lei $\mathrm{n}^{\circ}$ 10.303/01 envolveu diretamente o regime aplicável aos derivativos, trazendo uma radical (e criticável) mudança em seu tratamento legal.

No regime até então vigente, cabia à CVM regular os derivativos cujos ativos subjacentes estavam sujeitos à sua competência (por exemplo, ações), enquanto os demais derivativos estavam submetidos à regulação do Banco Central do Brasil (“BACEN”). ${ }^{37}$

\footnotetext{
${ }^{35}$ No mesmo artigo, também é abordada a compensação e liquidação de obrigações no âmbito do Sistema Financeiro Nacional, tema que será aprofundado na Segunda Parte deste estudo.

${ }^{36}$ Cf. NETO, Eduardo Salomão. Direito Bancário. p. 352.

${ }^{37}$ Cf. CHEDIAK, Julian Fonseca Peña. A Reforma do Mercado de Valores Mobiliários. In: LOBO, Jorge; KANDIR, Antonio (Coords.). Reforma da Lei das Sociedades Anônimas: inovações
} 
Com o advento da Lei $n^{\circ} 10.303 / 01$, a competência da CVM foi ampliada de forma a abranger todos os derivativos, sejam ou não seus ativos subjacentes considerados valores mobiliários. Tal decisão se fundamentou na compreensão de que haveria maior proximidade entre os derivativos e o mercado de valores mobiliários, do que haveria entre esses instrumentos e o mercado de crédito. Nesse sentido, vejamos a passagem do professor Julian Chediak:

\begin{abstract}
"Ainda que a regulação do mercado de valores mobiliários seja mais adequada para operações com títulos passíveis de negociação em mercado secundário - foi com base nesse tipo de título que o mercado de valores mobiliários se desenvolveu - os contratos de swap não parecem ser incompatíveis com tal forma de regulação. Do ponto de vista jurídico, a diferença mais importante entre o mercado de crédito e o de valores mobiliários - a existência ou não de uma intermediação efetiva por instituições especializadas, conforme acima visto - leva a que se conclua fazer mais sentido manter as operacões com swaps no âmbito das bolsas de valores, ou do mercado de balcão organizado, já que em tais operacõos existe um contato direto entre os comitentes, as instituições que operam no mercado têm a função de mera aproximação, e não de substituicão dos agentes.
\end{abstract}

Pode-se até criticar a posição do legislador, com base no fato de que está trazendo para a regulação da Comissão de Valores Mobiliários operações que, a rigor, não gerariam relações jurídicas idênticas ou substancialmente semelhantes às das demais operações reguladas por tal agência. Sem dúvida, porém, entre levar as operacões com swaps para o âmbito do mercado de crédito - e da fiscalização do Banco Central do Brasil - ou levá-las para o âmbito do mercado de valores mobiliários, essa última decisão parece ser a mais acertada. $(. .$.

Chegando-se à conclusão de que faz sentido trazer as operacões com swaps para o âmbito do mercado de valores mobiliários, com mais razão se pode aceitar trazer os contratos futuros de mercadorias. Nesse último caso, as operações se assemelham muito com as realizadas em qualquer mercado secundário de ações. E as instituições são daquelas que fazem a aproximação, e não a substituição dos agentes." (grifos nossos) ${ }^{38}$

Entretanto, a referida ampliação de competência da CVM não seguiu a melhor técnica. Em vez de submeter os valores mobiliários $\underline{e}$ os

e questões controvertidas da Lei 10.303, de 31.10.2001. 2 ${ }^{\mathrm{a}}$ Ed., Rio de Janeiro: Forense, 2002, p. 530.

${ }^{38}$ Cf. CHEDIAK, Julian Fonseca Peña. A Reforma do Mercado de Valores Mobiliários. In: LOBO, Jorge; KANDIR, Antonio (Coords.). Reforma da Lei das Sociedades Anônimas: inovações e questões controvertidas da Lei 10.303, de 31.10.2001 . pp. 532-533. 
derivativos em geral à regulação por essa agência, a Lei n ${ }^{\circ}$ 10.303/01 incluiu os derivativos no rol previsto no art. $2^{\circ}$ da Lei $n^{\circ} 6.385 / 76$, que define os valores mobiliários, pretendendo uma equiparação entre noções fundamentalmente distintas. O referido artigo, então, passou a dispor que são valores mobiliários, entre outros:

"VII - os contratos futuros, de opções e outros derivativos, cujos ativos subjacentes sejam valores mobiliários;

VIII - outros contratos derivativos, independentemente dos ativos subjacentes;"

Uma primeira crítica se relaciona à péssima redação empregada nos dispositivos acima. Como exposto pelo professor Nelson Eizirik:

"Ora, se o inciso VIII considera como valores mobiliários todos os contratos derivativos, quaisquer que sejam os 'ativos subjacentes', a teor da sua dicção, qual a razão de ser do inciso VII? Trata-se de dispositivos não só pessimamente redigidos como também redundantes, uma vez que bastaria dizer 'todos os contratos derivativos'." 39

Além disso, tal abordagem também criou um campo de incerteza no conceito de valor mobiliário e, consequentemente, nas hipóteses em que a competência da CVM irá se aplicar.

No Direito Norte-Americano, existe definição legal de security que, de certa forma, é restritiva como na Lei $\mathrm{n}^{\circ}$ 6.385/76. Contudo, ao enumerar os valores mobiliários (securities), o legislador norte-americano não conceituou os denominados investment contracts, o que foi posteriormente realizado pelo poder judiciário, notadamente no caso SEC v. W. J. Howey Company. ${ }^{40}$

Esse leading case tratou da venda de pequenos lotes de terra para plantio, enquanto uma subsidiária da vendedora prestava os serviços de

\footnotetext{
${ }^{39}$ EIZIRIK, Nelson; GAAL, Ariádna B.; PARENTE, Flávia; HENRIQUES, Marcus de Freitas. Mercado de capitais: regime jurídico. Rio de Janeiro: Renovar, 2008, p. 115

${ }^{40}$ Cf. CHEDIAK, Julian Fonseca Peña. A Reforma do Mercado de Valores Mobiliários. In: LOBO, Jorge; KANDIR, Antonio (Coords.). Reforma da Lei das Sociedades Anônimas: inovações e questões controvertidas da Lei 10.303, de 31.10.2001. p. 534.
} 
plantio e cultivo, assim como de comercialização dos produtos. A Suprema Corte identificou que, no caso, os investidores adotavam posição tipicamente passiva e, com base nisso, definiu investment contract como:

"toda transação através da qual uma pessoa aplica o seu dinheiro em um empreendimento comum, com o objetivo de obter lucro, em virtude exclusivamente de esforços que venham a ser desenvolvidos pelo lançador ou por uma terceira pessoa" 41

E, de forma genérica, essa definição acabou por se confundir com a própria definição de security. A partir disso, o paradigmático conceito de investment contract se refletiu no Direito Brasileiro por força da Medida Provisória $\mathrm{n}^{\mathrm{o}} 1.637$, posteriormente convertida na Lei $\mathrm{n}^{\mathrm{o}} 10.198 / 01$, que definiu contratos de investimento coletivo em linha quase idêntica à adotada no Direito Norte-Americano. Contudo, a Lei 10.303/01 modificou drasticamente esse cenário ao estabelecer, em seu art. $2^{\circ}$, uma equiparação entre os valores mobiliários e os derivativos - aliás, sem sequer definir o que seria um derivativo. ${ }^{42}$

Ora, os derivativos exercem função distinta dos valores mobiliários, não se destinando ao financiamento da atividade empresarial, mas ao gerenciamento de riscos de mercado. ${ }^{43}$ Além disso, o conteúdo trazido pela noção de derivativos é extremamente amplo e muitas vezes esses instrumentos se apresentam como relações intuitu personae, não se submetendo a distribuições públicas ou negociação (como ocorre nas

\footnotetext{
${ }^{41}$ CHEDIAK, Julian Fonseca Peña. A Reforma do Mercado de Valores Mobiliários. In: LOBO, Jorge; KANDIR, Antonio (Coords.). Reforma da Lei das Sociedades Anônimas: inovações e questões controvertidas da Lei 10.303, de 31.10.2001 . p. 535.

${ }^{42}$ Ibid., pp. 535-536. Vide-se o conceito adotado pela legislação nacional, antes da reforma promovida pela Lei $\mathrm{n}^{\circ} 10.303 / 01$, no art. $1^{\circ}$, caput, da Lei 10.198/01: "Constituem valores mobiliários, sujeitos ao regime da Lei $\mathrm{n}^{\mathrm{o}} 6.385$, de 7 de dezembro de 1976, quando ofertados publicamente, os títulos ou contratos de investimento coletivo, que gerem direito de participação, de parceria ou de remuneração, inclusive resultante de prestação de serviços, cujos rendimentos advêm do esforço do empreendedor ou de terceiros."

${ }^{43}$ Nesse sentido, indaga Daniel Goldberg: "Se a função primacial dos derivativos é a de transformar, transferir e realocar risco, em que medida ela converge com a função dos valores mobiliários (entendidos como contratos de investimento)?" (GOLDBERG, Daniel Krepel. A Lei 10.303, de 2001, e a inclusão dos derivativos no rol dos valores mobiliários. p. 77)
} 
relações entre bancos e clientes). A equiparação, portanto, promoveu uma distorção no conceito de valor mobiliário adotado pela legislação nacional, resultando (i) em um espectro de insegurança quando do enquadramento de instrumentos financeiros nessa categoria, e (ii) a rigor, na aplicação das normas relativas aos valores mobiliários para os derivativos. ${ }^{44}$

Críticas à parte, a mudança legislativa foi implementada e para absorção pela CVM da competência relativa aos derivativos antes submetidos ao BACEN, foi editada a Decisão Conjunta BACEN/CVM n ${ }^{\circ}$ 10, de 2 de maio de 2002, a qual esclarece que permanecem em vigor as disposições sobre derivativos baixadas pelo Conselho Monetário Nacional (“ $\underline{\mathrm{CMN}}$ ") e pelo BACEN, enquanto a CVM não editar normas que as sucedam. Assim, a CVM passou a exercer a fiscalização atribuída pela Lei $\mathrm{n}^{\mathrm{o}} 10.303 / 01$ com base nas normas baixadas pelo CMN e pelo BACEN, até a edição de normas próprias. ${ }^{45}$

\subsection{Abordagem Regulamentar}

Recentemente, pôde-se notar os primeiros passos de um esforço regulamentar da CVM no que tange ao conceito de derivativos. A Deliberação CVM nº 604/09 aprovou o Pronunciamento Técnico no 38, emitido pelo Comitê de Pronunciamentos Contábeis (CPC), como forma de recepcionar as normas contábeis internacionais sobre instrumentos financeiros $n^{\circ} 39$ (IAS 39). No referido Pronunciamento Técnico, há previsão de um conceito de derivativos a partir de três características: (i) alteração de valor em resposta à alteração em certo ativo subjacente; (ii)

\footnotetext{
${ }^{44}$ Cf. YAZBEK, Otavio. Regulação do Mercado Financeiro e de Capitais. p. 128; e CHEDIAK, Julian Fonseca Peña. A Reforma do Mercado de Valores Mobiliários. In: LOBO, Jorge; KANDIR, Antonio (Coords.). Reforma da Lei das Sociedades Anônimas: inovações e questões controvertidas da Lei 10.303, de 31.10.2001. pp. 535-536.

${ }^{45}$ Cf. EIZIRIK, Nelson; GAAL, Ariádna B.; PARENTE, Flávia; HENRIQUES, Marcus de Freitas. Mercado de capitais: regime jurídico. pp. 115-116. Destaque-se, ainda, que em 28 de outubro de 2010, foi celebrado um Convênio entre o BACEN e a CVM visando à atuação coordenada na supervisão de atividades sujeitas à competência de ambas as autarquias, incluindo os derivativos.
} 
investimento inicial nulo ou ínfimo; e (iii) liquidação futura. ${ }^{46}$ Fora essa norma, há apenas do conceito superficial trazido pela Instrução CVM n 283/98, a qual dispõe que:

“Art. $1^{\circ}$ São regulados pelas disposições da presente Instrução os mercados de liquidação futura. Parágrafo único. Mercado de liquidação futura, para os fins desta Instrução, é o mercado a termo, a futuro, de opções, ou qualquer outro que mantenha pregão ou sistema eletrônico para a negociação de valores mobiliários com liquidação em prazo superior ao estabelecido para os negócios no mercado à vista, sob a supervisão e fiscalização de entidade auto-reguladora."

\subsection{Perspectiva Jurisprudencial e Doutrinária}

As decisões judiciais e administrativas sobre o tema ainda não permitem identificar um standard do conceito de derivativos. A nosso ver, isso decorre principalmente dos seguintes fatores: (i) a complexidade do tema e a insuficiência das definições mais clássicas; ${ }^{47}$ (ii) uma parcela relevante das negociações no país ser realizada em ambiente de bolsa (BM\&FBovespa), no qual os instrumentos padronizados dificultam o processo de inovação; (iii) em consequência, uma grande parte do volume negociado no Brasil envolver estruturas clássicas dos derivativos, concentrando sua supervisão mais sobre os aspectos de negociação e menos sobre sua caracterização; (iv) as demandas judiciais sobre o tema se concentram na discussão dos efeitos de um derivativo específico (por exemplo, um swap), reduzindo a importância da conceituação de

\footnotetext{
${ }^{46}$ Deliberação CVM no 604/09, Pronunciamento Técnico CPC 38, Definições, Item 9 (Definição de Derivativo). Destaque-se, contudo, que não necessariamente o investimento inicial em um derivativo é "nulo ou ínfimo", uma vez que, por exemplo, é possível a estipulação de prêmio em valor considerável quando comparado ao valor da respectiva opção.

${ }^{47}$ Nesse sentido, o Diretor Otavio Yazbek apresentou a seguinte ponderação ao analisar as Reduções Certificadas de Emissão (RCEs) frente à definição de derivativo: "De um modo geral, não se encontram definições para tal expressão que não em manuais de finanças e, no mais das vezes, essas definições são vazadas em termos bem simples: algo na linha 'derivativos são todos os instrumentos que retiram o seu valor de outras relações ou de outros instrumentos'. Como se pode ver, a definição é baseada exclusivamente no processo de apreçamento dos instrumentos que se procura definir. Assim, se os ativos propriamente ditos têm seus preços definidos em razão do seu conteúdo - dos bens ou dos feixes de direitos e de deveres neles embutidos -, os derivativos são apreçados a partir de outras relações." (Voto proferido no âmbito do Processo CVM no RJ 2009/6346, julgado em 07.07.2009).
} 
derivativos em sentido amplo; e (v) a amplitude da definição de valor mobiliário, em alguns casos, retira a importância da discussão sobre a natureza dos derivativos, visto que a competência da CVM poderá se aplicar por outras características do instrumento. ${ }^{48}$

Com base na regulamentação fragmentada e no vácuo deixado pela jurisprudência nacional, a doutrina normalmente se socorre das definições econômicas mais clássicas, sem se aprofundar em seu conceito jurídico. Por exceção, destaca-se o conceito adotado pela professora Rachel Sztajn, inspirada na lição de John Hull, ao definir derivativos como:

"contratos ou declarações unilaterais cujo valor depende de outros bens ou variáveis resultantes, experimentados por força de posição em outros negócios, ditos subjacentes" 49

\subsection{Um Dilema Conceitual}

Em síntese, o estudo dos derivativos tem como ponto de partida uma problemática conceitual. Inclusive, porque se discute a própria existência de traços fundamentais em todos os instrumentos que compõem os mercados de derivativos. ${ }^{50}$

\footnotetext{
${ }^{48}$ Foi o que ocorreu no Processo CVM n ${ }^{\circ}$ RJ 2003/0499, julgado em 28.08.2003, que tratou dos Certificados de Potencial Adicional de Construção (CEPACs). Vejamos trecho do voto proferido pelo Diretor Relator Luiz Antonio de Sampaio Campos, acompanhado pelos demais membros do Colegiado: "No caso presente é irrelevante a classificação do instrumento, posto que seja um Contrato de Investimento Coletivo ou seja um derivativo, a solucão jurídica aplicável - e bem assim o regime jurídico - é a mesma, que é trazề-lo para a competência da Comissão de Valores Mobiliários. Da estrutura apresentada para os CEPACs ressalta evidente a oferta ao público para captação de recursos. Isto já de si deveria ser suficiente para se afirmar que o instrumento deveria, quando assim ofertado, estar sujeito à competência da CVM. Examinando mais detidamente os contornos dos CEPACs entendo que as características de um contrato de investimento coletivo estão presentes." (grifos nossos)
}

${ }^{49}$ SZTAJN, Rachel. Futuros e swaps: uma visão jurídica. São Paulo: Cultural Paulista, 1998, p. 149. Citando a referida autora, Daniel Goldberg também adota esse conceito de derivativos (GOLDBERG, Daniel Krepel. A Lei 10.303, de 2001, e a inclusão dos derivativos no rol dos valores mobiliários. p. 76).

\footnotetext{
${ }^{50}$ Sobre o tema, o professor Julian Chediak afirma que: "Na categoria de derivativos são incluídos títulos (ou contratos) de natureza absolutamente diversa, tanto do ponto de vista jurídico como econômico. $\mathrm{O}$ que tem um contrato em que duas pessoas trocam as taxas aplicáveis em financiamentos por elas celebrados com terceiros (swap) a ver com um contrato futuro de venda de mercadoria, em que o preço será pago e a mercadoria será entregue em data futura (ou, mais comumente, em que haverá a liquidação por diferença)?" (grifos originais) (CHEDIAK, Julian Fonseca Peña. A Reforma do Mercado de Valores Mobiliários. In: LOBO, Jorge; KANDIR,
} 
Em âmbito jurídico, resta saber se o regulador caminhará para uma técnica enumerativa (ainda que sob sacrifício do rigor técnico) ou adotará um conceito único e fechado, como o previsto no Pronunciamento Técnico $\mathrm{n}^{\circ}$ 39. Trata-se, pois, de uma questão em aberto.

\section{Capítulo II - Funções Econômicas e Agentes de Mercado}

\section{As Funções Econômicas dos Derivativos}

Os derivativos surgiram como mecanismos de proteção patrimonial contra variações nos preços de produtos agropecuários (hedge), sendo essa sua função econômica mais tradicional. Contudo, o desenvolvimento dos mercados permitiu que os derivativos cumprissem uma série de outras funções de grande relevo para a atividade econômica e, em última instância, para a própria sociedade. Com base nos ensinamentos de Ernesto Lozardo, esclarece o professor Nelson Eizirik sobre os mercados futuros:

"O mercado futuro tem cinco funções básicas: auxiliar a administração de risco inerente ao comportamento do preço futuro, propiciar a difusão de preços, minimizar o impacto negativo de novas informações econômicas, diminuir a sazonalidade de preços entre safras e indicar o preço futuro do ativo." ${ }^{51}$

A função de informar mencionada acima também é explorada pela professora Rachel Sztajn, ao analisar os derivativos frente ao disposto no art. 421 do Código Civil, que trata da função social do contrato:

\footnotetext{
"Talvez se possa pensar na função social do mercado de derivativos que serve para dar indicação da tendência de preços futuros, ou mesmo gerar informações de interesse para a comunidade pelo que devem ser protegidos os contratos dele decorrentes." 52
}

\footnotetext{
Antonio (Coords.). Reforma da Lei das Sociedades Anônimas: inovações e questões controvertidas da Lei 10.303, de 31.10.2001. p. 536).

${ }^{51}$ EIZIRIK, Nelson; GAAL, Ariádna B.; PARENTE, Flávia; HENRIQUES, Marcus de Freitas. Mercado de capitais: regime jurídico. p. 113.

${ }^{52}$ SZTAJN, Rachel. Regulação e o Mercado de Valores Mobiliários. p. 144.
} 
Também abordando o mercado futuro, em razão de sua centralidade no mundo dos derivativos, o professor Otavio Yazbek destaca que o desenvolvimento desse mercado (i) atrai capital de risco dos especuladores (ampliando a liquidez), (ii) leva, indiretamente, à diminuição dos preços dos bens ao permitir a transferência de risco pelos produtores, assim como (iii) permite a redução dos custos de financiamento das atividades produtivas, visto que o risco dos agentes financiadores será menor caso as pessoas financiadas estejam hedgeadas. ${ }^{53}$

Encontra-se, ainda, referência a uma função de privatização de riscos. Em outras palavras, como é permitido aos particulares comprar e vender riscos por meio do mercado de derivativos, o governo pode eliminar sua participação em determinados tipos de riscos. ${ }^{54}$

\section{Um "Negócio de Risco"}

A partir das funções econômicas expostas acima, podemos concluir que os derivativos não visam à simples circulação dos ativos-objeto (sejam ações, mercadorias, etc), pois sua finalidade principal é gerenciar os riscos que afetam o valor de tais bens. Conforme leciona Carlos Augusto da Silveira Lobo:

"Como a causa do vínculo contratual é a transferência de riscos referentes a posições futuras, e não a transferência de uma coisa, na grande maioria dos casos os contratos futuros são liquidados por diferença (...) A principal função dos mercados futuros não é, portanto, propiciar a circulação de mercadorias e produtos agrícolas, mas sim assegurar aos agentes econômicos, que, pela natureza de suas atividades, se sujeitam naturalmente a riscos de determinada natureza, um mecanismo eficaz (o hedging) para se protegerem contra os riscos decorrentes de mudanças de preços no futuro. São esses riscos o objeto das negociações; não as

\footnotetext{
${ }^{53}$ Cf. YAZBEK, Otavio. Regulação do Mercado Financeiro e de Capitais. Rio de Janeiro: Elsevier, 2007, p. 112.

${ }^{54}$ A explicação é apresentada pelo professor Haroldo Verçosa, citando material elaborado pelo Banco Central do Brasil (VERÇOSA, Haroldo Malheiros Duclerc. Negócios com opções - a opção flexível. Revista de Direito Mercantil. São Paulo: Malheiros, 1999, vol. 114, p. 63).
} 
mercadorias ou outros ativos, que servem de base aos contratos de futuros." (grifos nossos) ${ }^{55}$

Aliás, inúmeras negociações são realizadas com base em ativos financeiros, cuja entrega física não é possível, ficando ainda mais evidente a desvinculação ao ativo de referência. Como bem sintetizado por Merton Miller ao tratar da negociação envolvendo índices:

“(...) that's essentially what you can do these days with index derivative futures: leave the physical assets in place and just move their returns." 56

Entretanto, ainda que ocorra a efetiva circulação do bem, por exemplo, no caso do exercício de uma opção de compra de ações, não é este o objetivo da operação, mas sim a transferência do risco de variação de seu preço. Do contrário, bastaria ao agente adquirir tais ações no mercado à vista. $^{57}$

Assim, entendemos que a análise jurídica dos derivativos não deve estar apegada a arcaicos cânones civilistas ou a tipos contratuais supostamente imutáveis, sob pena de uma leitura incompleta ou distorcida da realidade, com evidentes prejuízos ao desenvolvimento econômico. O intérprete deve estar aberto a reconhecer a atipicidade de certos pactos ou, ainda que diante de contratos típicos, notar se as partes não almejaram uma

\footnotetext{
${ }^{55}$ LOBO, Carlos Augusto da Silveira. Os mercados de futuros. pp. 149-150. Em outras palavras, esclarece o professor Nelson Eizirik: "Nos mercados futuros, negociam-se contratos de risco sobre as expectativas de variação de preços futuros de ativos negociados no mercado à vista" (grifos nossos). No mesmo sentido, é a opinião de Otavio Yazbek: "A negociacão de 'expectativas' nesse tipo de mercado, permissiva de atividades marcadamente especulativas, ajudou a atrair novos agentes para nele operar, e, ao mesmo tempo, colocou os derivativos no centro dos debates sobre escândalos financeiros" (grifos nossos) (EIZIRIK, Nelson; GAAL, Ariádna B.; PARENTE, Flávia; HENRIQUES, Marcus de Freitas. Mercado de capitais: regime jurídico. p. 113; e YAZBEK, Otavio. Regulação do Mercado Financeiro e de Capitais. p. 106).

${ }^{56}$ MILLER, Merton H. Merton Miller on Derivatives. New York: John Wiley and Sons, 1997, p. 88.

${ }^{57}$ Cf. EIZIRIK, Nelson. Aspectos jurídicos dos mercados futuros. p. 25.
} 
função atípica. ${ }^{58}$ Nesse sentido, é a opinião do professor Haroldo Verçosa, ao tratar das opções:

\begin{abstract}
"Ao vir a enfrentar questões nessas áreas, o Judiciário deverá estar atento para a especialidade do instituto, não fazendo recair sobre elas um direito rançoso de uma época ultrapassada, mas, isto sim, resolvendo-as de acordo com uma visão moderna, identificadora da existência de novos negócios, construídos para novas finalidades econômicas válidas, baseados em velhos e novos princípios, em funcionamento perfeitamente equilibrado entre si." ${ }^{59}$
\end{abstract}

Essa visão também já foi exposta pelo professor Arnoldo Wald, em interessante artigo publicado no ano de 1978, tratando do financiamento de operações a termo por corretoras. Nas palavras deste autor:

"Em matéria de direito administrativo, como de direito tributário, o que importa na interpretação das resoluções governamentais não é a denominação dada às figuras jurídicas utilizadas, mas sim a verdadeira estrutura econômica da operação. Deve prevalecer, pois, para que se verifique a legalidade ou ilegalidade de uma transação no sistema financeiro, a visão global e dinâmica da operação no seu conjunto e não a decomposição da mesma em unidades abstratas e fictícias, numa concepcão atomista que desfigura a realidade. (...) $\underline{O}$ que deve prevalecer no caso, para a adequada interpretação da lei, é a consistência econômica da operacão, ou seja, a relacão econômica, pouco importando a sua forma externa, conforme tem aliás, entendido a Suprema Corte norte-americana no caso Higgins V. Smith (V. a respeito Amílcar de Araújo Falcão, Introdução ao Direito Tributário, Rio, Edições Financeiras, 1959 , p. 94 e ss.)." (grifos nossos) ${ }^{60}$

\title{
5. Lesão e Onerosidade Excessiva
}

A partir das reflexões acima, pode-se afirmar que os contratos de derivativos são tipicamente aleatórios. Nesses instrumentos, a existência de risco é justamente o pressuposto para que desempenhem suas funções econômicas. Aliás, a própria obtenção do preço a partir de um ativo

\footnotetext{
${ }^{58}$ A utilização de contratos típicos para funções atípicas é destacada pela professora Rachel Sztajn, bem como por Eduardo Salomão Neto, este apoiado na doutrina de Tullio Ascarelli sobre os denominados negócios jurídicos indiretos (SZTAJN, Rachel. Futuros e swaps: uma visão jurídica. p. 150; e NETO, Eduardo Salomão. Direito Bancário. pp. 334-335).

${ }^{59}$ VERÇOSA, Haroldo Malheiros Duclerc. Negócios com opções - a opção flexível. p. 67.

${ }^{60}$ WALD, Arnoldo. As corretoras e o financiamento de operações a termo (aspectos jurídicos do problema). Revista de Direito Mercantil. São Paulo: Revista dos Tribunais, 1976, vol. 29, p. 21.
} 
subjacente, por si, já resulta na existência de risco, visto que elementos distintos (derivativo e ativo subjacente) podem estar sujeitos a influências também distintas. Portanto, o risco é elemento intrínseco dos derivativos, sem o qual essa categoria de instrumentos simplesmente deixaria de existir.

Além disso, os derivativos são operações tipicamente empresariais, de modo que um nível de expertise no assunto pode ser, desde logo, presumido. $^{61}$

Nesse cenário, a aplicação de institutos como a lesão (art. 157 do Código Civil) e a onerosidade excessiva (arts. 478 e segs. do Código Civil) apresenta-se extremante tormentosa. No que tange à lesão, inclusive, autoridades no assunto já repudiaram sua aplicação ao direito comercial. ${ }^{62}$

Sendo assim, a posição dominante entende pela inaplicabilidade de tais institutos aos derivativos, sendo bem representativo o trecho de parecer elaborado pela professora Judith Martins-Costa, ao ser consultada sobre a aplicação da Teoria da Imprevisão a derivativos cambiais, diante da crise internacional de 2008:

\begin{abstract}
"Não, por uma tríplice ordem de razões: os contratos pactuados são aleatórios e não comutativos; a possibilidade de uma intensa variação cambial constituía justamente a álea própria dos negócios de derivativos, isto é, o risco apreendido pela sua causa ou função econômica. Assim sendo, esse risco integra a sua álea normal. Além do mais, a própria extraordinariedade dos níveis de variação cambial, consequente ao credit crunch de 2008, era previsível, pela leitura dos jornais, desde pelo menos um ano antes, não sendo fenômeno incognoscível por
\end{abstract}

\footnotetext{
${ }^{61}$ Embora a negociação de derivativos por pessoas físicas seja comum nos mercados de bolsa ou diretamente entre uma instituição financeira e seu cliente. Nesses casos, é evidente a necessidade de expor os riscos de maneira adequada, de forma que o instrumento financeiro contratado seja adequado ao perfil de cada investidor (suitability). Tais situações ainda podem resultar em aplicação das regras de defesa do consumidor, assim como comportam uma série de outras considerações relevantes para a aplicação dos institutos da lesão ou da onerosidade excessiva, o que foge ao escopo do presente estudo. Para um aprofundamento nessas questões, remetemos o leitor às seguintes obras: FILHO, Luiz Gastão Leães. Derivatives Suitability. Revista de Direito Mercantil. São Paulo: Revista do Tribunais, 1996, vol. 102, pp. 59-71; e NETO, Eduardo Salomão. Direito Bancário. pp. 355-359.

${ }^{62}$ Nas palavras da professora Paula Forgioni: "Caio Mário da Silva Pereira, valendo-se das lições de Bento de Faria e de Carvalho de Mendonça, em monografia sobre a lesão, partindo da análise do art. 220, também admite que, segundo a doutrina comercialista, o instituto não integra o sistema de direito comercial." (FORGIONI, Paula A. Teoria geral dos contratos empresariais. São Paulo: Revista dos Tribunais, 2010, p. 248).
} 
empresários que, profissionalmente, atuam na área da exportação de produtos (itens 51 a 56)." (grifos originais) ${ }^{63}$

Aliás, o Superior Tribunal de Justiça já se pronunciou nesse sentido ao tratar da compra e venda futura de soja, em acórdão unânime proferido em 3 de novembro de 2011, cuja ementa transcrevemos abaixo:

\begin{abstract}
"DIREITO EMPRESARIAL. CONTRATOS. COMPRA E VENDA DE COISA FUTURA (SOJA). TEORIA DA IMPREVISÃO. ONEROSIDADE EXCESSIVA. INAPLICABILIDADE.

1. Contratos empresariais não devem ser tratados da mesma forma que contratos cíveis em geral ou contratos de consumo. Nestes admite-se o dirigismo contratual. Naqueles devem prevalecer os princípios da autonomia da vontade e da força obrigatória das avenças.
\end{abstract}

2. Direito Civil e Direito Empresarial, ainda que ramos do Direito Privado, submetem-se a regras e princípios próprios. O fato de o Código Civil de 2002 ter submetido os contratos cíveis e empresariais às mesmas regras gerais não significa que estes contratos sejam essencialmente iguais.

3. O caso dos autos tem peculiaridades que impedem a aplicação da teoria da imprevisão, de que trata o art. 478 do CC/2002: (i) os contratos em discussão não são de execução continuada ou diferida, mas contratos de compra e venda de coisa futura, a preço fixo, (ii) a alta do preço da soja não tornou a prestação de uma das partes excessivamente onerosa, mas apenas reduziu o lucro esperado pelo produtor rural e (iii) a variação cambial que alterou a cotação da soja não configurou um acontecimento extraordinário e imprevisivel, porque ambas as partes contratantes conhecem o mercado em que atuam, pois são profissionais do ramo e sabem que tais flutuacões são possíveis.

5. Recurso especial conhecido e provido." (grifos nossos) ${ }^{64}$

Ressalta-se, todavia, que a questão não pode ser declarada pacífica no direito pátrio. Por exemplo, no processo acima citado, a teoria da imprevisão foi aplicada em primeira instância, sendo tal decisão ainda mantida pelo Tribunal de Justiça do Estado de Goiás, em acórdão cuja ementa contém o seguinte trecho:

\begin{abstract}
"Cabe portanto ao Judiciário repelir as práticas abusivas do mercado para coibir principalmente o lucro excessivo de um em detrimento do prejuízo de outrem, revisando ou declarando nulas as cláusulas contratuais que ocasionem um desequilíbrio flagrante entre os contratantes."
\end{abstract}

\footnotetext{
${ }^{63}$ MARTINS-COSTA, Judith. Contratos de Derivativos Cambiais. Contratos Aleatórios. Abuso de Direito e Abusividade Contratual. Boa-fé objetiva (Parecer). Revista de Direito Bancário e do Mercado de Capitais. São Paulo: Revista dos Tribunais, 2012, vol. 55, p. 328.

${ }^{64}$ STJ, REsp no 936.741 - GO, Rel. Ministro Antonio Carlos Ferreira, Brasília, 3 de novembro de 2011.
} 
Além disso, pode-se encontrar na doutrina subsídios para se sustentar a aplicação desses institutos aos derivativos. Por exemplo, em obra sobre a revisão dos contratos, Laura Coradini Frantz apresenta observação, no mínimo curiosa, sobre a aplicação desses institutos aos contratos aleatórios:

\begin{abstract}
“(...) a legislação italiana, fonte de inspiração para a brasileira, pelo menos no que tange aos institutos que tutelam o sinalagma, veda expressamente a hipótese de se submeterem os contratos aleatórios a um 'controle de equilíbrio', não permitindo a aplicação da rescisão por lesão nem da resolução por excessiva onerosidade aos contratos aleatórios. Contudo, o novo Código Civil não faz menção expressa à hipótese, o que permite supor sua admissibilidade." (grifos nossos) ${ }^{65}$
\end{abstract}

Em vista disso e de outros motivos, a autora conclui pela possibilidade de aplicação do instituto da excessiva onerosidade aos contratos aleatórios, desde que o risco que incida seja extraordinário, isto é, esteja fora da álea normal e extrapole os riscos de perdas e ganhos de qualquer contrato aleatório. ${ }^{66}$

Em síntese, a aplicação dos institutos da lesão e da onerosidade excessiva aos derivativos, em regra, não é admitida. Porém, é possível encontrar decisões esparsas, assim como entendimentos doutrinários, que se inclinam a sua aplicação e, por conseguinte, evidenciam certa fragilidade na posição dominante.

\title{
6. Hedger
}

Caso um agente atue no mercado à vista, a realização de uma operação com derivativo em sentido oposto e na mesma proporção negociada à vista, em tese, irá anular os efeitos da variação de preço. Nesse caso, dizemos que o vendedor transferiu o risco de queda no preço para o

\footnotetext{
${ }^{65}$ FRANTZ, Laura Coradini. Revisão dos contratos: elementos para sua construção dogmática. São Paulo: Saraiva, 2007. pp. 160-161.

${ }^{66}$ FRANTZ, Laura Coradini. Revisão dos contratos: elementos para sua construção dogmática. p. 166.
} 
comprador, enquanto o comprador transferiu o risco de alta no preço para o vendedor. Em outras palavras, ensina o professor Nelson Eizirik:

"Como o preço da mercadoria no futuro pode diferir do preço fixado pelas partes, existe nitidamente um processo de transferência de riscos no mercado" 67

Assim, entende-se que o agente realizou uma operação conhecida como hedge ou hedging. ${ }^{68}$ Vejamos o exemplo abaixo envolvendo um Contrato Futuro de Soja.

Um produtor de soja está preocupado com a queda no preço de sua próxima safra $\left(\mathrm{P}_{\text {Futuro }}\right)$ em razão da expectativa de grande produtividade para o setor. Considerando esse risco, o produtor contrata, desde já, a venda de sua safra futura por um preço preestabelecido $\left(\mathrm{P}_{\text {Parâmetro }}\right)$, estipulando que a operação será liquidada por meio do pagamento da variação entre $\mathrm{P}_{\text {Parâmetro }}$

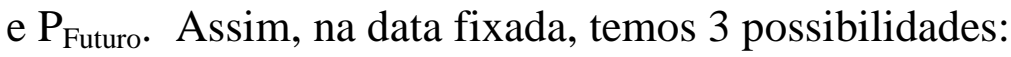

1) Alta no preço $\left(P_{\text {Futuro }}>P_{\text {Parâmetro }}\right)$ - a perda na venda à futuro é compensada pelo ganho na venda à vista;

2) Queda no preço $\left(\mathrm{P}_{\text {Futuro }}<\mathrm{P}_{\text {Parâmetro }}\right)$ - o ganho na venda à futuro é compensado pela perda na venda à vista; ou

3) Preço estável $\left(\mathrm{P}_{\text {Futuro }}=\mathrm{P}_{\text {Parâmetro }}\right)$ - a venda a futuro não gerará efeitos econômicos para as partes (excetuados os custos normalmente incorridos para a realização da operação).

Em síntese, o produtor abriu mão do ganho decorrente da alta no preço e, em contrapartida, não foi prejudicado pela perda decorrente de sua queda. Diz-se, portanto, que o produtor conseguiu transferir o risco de preço de sua safra, atuando como hedger.

\footnotetext{
${ }^{67}$ EIZIRIK, Nelson. Aspectos jurídicos dos mercados futuros. p. 24.

${ }^{68}$ Registre-se também a existência do denominado "hedge natural", caracterizado pela "posse de ativo e passivo na mesma moeda como, v.g., ocorre nas empresas que importam para investir num determinado setor e exportam um produto na mesma moeda" (TALAVERA, Glauber Moreno. Aspectos Elementares do Hedging. In: WAISBERG, Ivo; e FONTES, Marcos Rolim Fernandes (Coords.). Contratos bancários. p. 200)
} 
Ressalte-se, contudo, que o hedge não é uma espécie contratual, mas um efeito econômico de proteção (ou estabilização) obtido a partir da realização de operações em sentido oposto. ${ }^{69}$ Observa-se nessa situação uma mera interdependência factual, fundada em uma razão econômica. Não há uma composição de elementos de outros contratos, formando-se um contrato misto, ou, ainda, qualquer liame jurídico que traduza o fenômeno da coligação contratual, inclusive porque tais operações envolvem partes diferentes. Dessa forma, apesar da reciprocidade existente entre esses negócios, não há relação de dependência entre a existência e a validade de uma operação e de sua operação contrária. ${ }^{70}$

\section{Especulador}

Como visto acima, a expectativa sobre o futuro é um ponto central no funcionamento dos derivativos. Assim, é natural que oscilem com uma especial sensibilidade aos fatos, sendo sua resposta ainda potencializada pela alta velocidade envolvida em seus sistemas de negociação. Nesses instrumentos, uma dada variação no ativo-objeto, tende a resultar em uma variação de intensidade superior no derivativo (o que demonstra sua alta volatilidade). Por sua vez, o reduzido investimento inicial (em alguns casos, até inexistente), bem como a liquidação em data futura, permite aos agentes assumir posições sensivelmente superiores a sua capacidade econômica e, inclusive, sem lastro para a liquidação até o vencimento (conhecidas como posições "descobertas"). Assim, em um curto prazo e com pequena disponibilidade financeira, um agente está sujeito a incorrer em imensas

\footnotetext{
${ }^{69}$ A "função estabilizadora do hedging" é mencionada por Oscar Barreto Filho, em artigo clássico sobre o tema. Para esse autor, o hedging seria "uma figura extracontratual, que se define como uma operação econômica complexa" (FILHO, Oscar Barreto. As operações a termo sobre mercadorias ("hedging"). p.12)

${ }^{70}$ Cf. LEÃES, Luiz Gastão Paes de Barros. "Hedging” com futuros de indices representativos de ações. Revista de Direito Mercantil. São Paulo: Malheiros, 2001, vol. 124, p. 218; e FILHO, Oscar Barreto. Op. cit., pp.13-14.
} 
perdas ou auferir ganhos expressivos, traduzindo-se essa operação em uma estratégia de grande alavancagem.

A partir dessas características, os derivativos são diretamente associados à atividade especulativa. Mas, o que exatamente significa ser um especulador?

Dentre os diversos sentidos existentes, pode-se dizer que o especulador é alguém que não está realizando um hedge. Vejamos um interessante caso relatado por Merton Miller:

"I had the occasion recently to talk with the treasurer of a medium-size oil company in Chicago. He was moaning that, after the war in the Gulf ended, the price of oil dropped very sharply and the firm suffered substantial losses on its oil inventory.

I sad, 'Well, it serves you right for speculating and gambling.'

But, the treasurer insisted: 'Oh, no, we didn't speculate. We didn't use the futures market at all.'

'That's exactly the point,' I replied. 'When you hold inventory, non-hedging is gambling. You gambled that the price of oil would not drop and you lost." $\left(\right.$ grifos nossos) ${ }^{71}$

Isso demonstra a dificuldade em estabelecer distinções entre um simples investimento e uma estratégia especulativa. Inclusive, para alguns autores, a especulação seria nada mais que uma espécie de investimento em que o retorno obtido pode variar substancialmente em relação ao retorno esperado. $^{72}$

Apesar das discussões teóricas, os especuladores são normalmente identificados como os agentes que assumem os riscos de mercado em busca de um retorno, enquanto os hedgers seriam agentes que buscam proteção contra os riscos de mercado.

\footnotetext{
${ }^{71}$ MILLER, Merton H. Merton Miller on Derivatives. p. 81.

${ }^{72}$ TEWELES, Richard Jack; JONES, Frank Joseph. The futures games: who wins? who loses? why? $2^{\text {nd }}$ Ed. New York: McGraw-Hill, 1987. p. 5.
} 


\title{
8. Arbitrador
}

A denominada Lei do Preço Único diz que um mesmo bem não pode ser comercializado em um dado momento por preços diferentes. Quando essa lei é violada, surge a oportunidade de obter um retorno financeiro a partir da diferença entre os preços, prática conhecida como arbitragem. Nas palavras de Gustavo Franco:

\begin{abstract}
"Não há razão, por exemplo, para que o preço do feijão seja diferente entre diferentes regiões do país, exceto por custos de transporte. Se houver diferença ou 'desalinhamento', qualquer que seja o motivo, alguém esperto (e este não é um recurso escasso no país) poderá se engajar em uma atividade conhecida tecnicamente como 'arbitragem', que consiste em comprar onde está barato e vender onde está caro até os preços se igualarem. O 'arbitrador' funciona como o 'vaso comunicante' que assegura a 'paridade' entre os preços." ${ }^{73}$
\end{abstract}

De um modo geral, menciona-se que a arbitragem envolve a fixação de um lucro sem risco, a partir da realização de operações simultaneamente em dois ou mais mercados. Assim, os arbitradores contribuiriam para um equilíbrio entre os preços em diferentes mercados à vista e entre os preços futuros e à vista. ${ }^{74}$

Observamos, contudo, que as estratégias de arbitragem envolvendo os mercados de derivativos podem, por vezes, confundir-se com o hedge e até a especulação. Apesar dos conceitos simples adotados no dia-a-dia dos mercados, uma análise mais aprofundada demonstra a dificuldade em estabelecer parâmetros claros de distinção em diversos casos. Assim, o enquadramento nessas categorias, a nosso ver, depende de uma avaliação concreta, considerando as peculiaridades de cada instrumento, bem como a circunstância em que o agente se encontrava ao realizar a operação.

\footnotetext{
${ }^{73}$ FRANCO, Gustavo H. B. Você acredita em teoria econômica? O Estado de São Paulo, 09 de novembro de 2001. Disponível em 〈http://www.econ.puc-rio.br/gfranco/a128.htm $>$. Acesso em 16 de junho de 2012.

${ }^{74}$ Cf. HULL, John. Options, futures, and other derivatives. p. 14; e BESSADA, Octavio; BARBEDO, Claudio; ARAÚJO, Gustavo Silva. Mercado de derivativos no Brasil: conceitos, operações e estratégias. $2^{\mathrm{a}}$ Ed. Rio de Janeiro: Record, 2007. p. 26.
} 


\section{Capítulo III - Mercados e Modalidades de Negociação}

\section{Autorregulação e Estruturas Contratuais}

Como visto acima, os derivativos são instrumentos financeiros de grande complexidade e risco, de forma que os agentes necessitam de especial segurança quanto aos seus termos e condições.

Normalmente, os panoramas legal e regulatório não dispõem da agilidade necessária para se adaptar às mudanças de mercado e, portanto, a autorregulação atua como importante ferramenta para complementar a regulamentação dos derivativos.

Os derivativos negociados em bolsa têm suas condições básicas fixadas em um contrato-padrão elaborado pelas entidades administradoras desses mercados. Já os contratos negociados em mercados de balcão, em regra, não se sujeitam a imposições sobre seus termos. Contudo, também não escapam de alguma padronização, considerando-se que a prática de mercado se amolda a padrões internacionais, ditados sobretudo pela International Swaps and Derivatives Association ("ISDA").

Entende-se que a uniformidade defendida por essas entidades é fundamental para o desenvolvimento dos derivativos, na medida em que contribui para sua eficiência, reduzindo o tempo de negociação e os custos incorridos pelas partes. $^{75}$

Uma das principais diretrizes internacionais da ISDA é a estrutura contratual de modelo guarda-chuva (umbrella). Trata-se de um sistema em que um acordo principal ou global (Master Agreement) contém os parâmetros mais genéricos do negócio, inclusive com opções sobre pontos negociais (por exemplo, foro competente ou hipóteses de vencimento antecipado). A partir desse instrumento, as partes celebram um aditivo (Schedule), adaptando os termos e condições do acordo global a sua

\footnotetext{
${ }^{75}$ Cf. NETO, Eduardo Salomão. Direito Bancário. p. 349.
} 
situação concreta. Então, as operações são celebradas por meio de confirmações (Confirmations), em que são especificados os dados mais concretos do negócio, como valores, prazos e ativo-objeto. Os termos definidos são normalmente estabelecidos em outro documento (Definitions) e, ainda, é possível que demais instrumentos complementem essa rede contratual, como ocorre com a Documentação de Apoio ao Crédito (Credit Support Annex) em credit default swaps. ${ }^{76}$

No Brasil, a segurança e a padronização têm especial atenção da CVM, uma vez que os modelos de contratos admitidos à negociação ou registrados em mercados organizados (bolsa ou balcão organizado) devem ser aprovados por essa autarquia antes do início das negociações, nos termos do art. $2^{\circ}$ da Instrução CVM nº 467/08.

\section{Negociações em Mercados de Bolsa e Balcão}

A crescente importância dos derivativos tornou sua negociação cada vez mais profissional e eficiente. Assim, relevante parcela dos acordos bilaterais migraram para as bolsas, onde estavam sujeitos a uma nova lógica, incluindo a participação de intermediários que representavam os agentes nos salões de negociação (conhecidos como traders).

Tradicionalmente, os negócios eram "fechados" a partir de um sistema de negociação denominado open outcry system, no qual os traders se encontravam fisicamente em um salão da bolsa, gritando e usando um conjunto de complicados sinais manuais para indicar as operações que desejavam realizar. $^{77}$

Posteriormente, o desenvolvimento tecnológico e a demanda por maior velocidade nas operações resultaram na implantação de sistemas eletrônicos de negociação, tanto em mercados de bolsa e como em

\footnotetext{
${ }^{76}$ Cf. NETO, Eduardo Salomão. Op. cit., pp. 349-350; e ALMEIDA, Samy Sanches de. Crise dos derivativos: reforma Dodd-Frank e o clearing centralizado. p. 170.

${ }^{77}$ Cf. HULL, John. Options, futures, and other derivatives. p. 2.
} 
mercados de balcão. O espaço virtual, então surgido, tornou nebulosa a distinção clássica entre bolsa e balcão, na medida em que permitiu leilões de ofertas também no mercado de balcão. ${ }^{78}$

Em linhas gerais, pode-se afirmar que o mercado de balcão, tradicionalmente, se contrapõe ao de bolsa por ser aquele em que os agentes realizam operações diretamente entre si, ou diretamente com seus clientes, sem um mecanismo centralizado e compulsório de formação de preços. ${ }^{79}$

Já o mercado de balcão organizado não se confunde com o mercado de balcão não-organizado, tendo em vista que o primeiro é supervisionado por instituição autorreguladora e pela própria CVM e o segundo não se sujeita à supervisão por entidade autorreguladora. ${ }^{80}$

No Brasil, atualmente, alguns derivativos são tipicamente negociados em bolsa (como opções sobre ações), enquanto outros têm maior presença em mercados de balcão organizado e não-organizado (por exemplo, os swaps).

$\mathrm{Na}$ esfera internacional, observamos que o menor controle sobre os derivativos de balcão (conhecidos como OTC ou over-the-counter) traduziu-se em mercados de dimensões superiores aos mercados de bolsa, bem como potencializou o processo de inovação financeira desses instrumentos. Por outro lado, em decorrência da crise internacional de 2008, os governos mundiais (principalmente, o norte-americano) passaram a

\footnotetext{
${ }^{78}$ NETO, Eduardo Salomão. Nova Regulamentação do Mercado de Balcão Organizado. Revista de Direito Mercantil. São Paulo: Malheiros, 1998, vol. 109, p. 102.

${ }^{79}$ Cf. YAZBEK, Otavio. Regulação do Mercado Financeiro e de Capitais. p. 143. No mesmo sentido, é a lição de Louis Loss: "There are several important differences between the stock exchanges and the OTC market. First and most obvious, each stock exchange provides a central place for trading where all costumers' buy and sell orders meet and the highest buy order is matched against the lower sell order in an auction type process; the OTC market, on the other hand, is a descentralized market in which transactions are negociated among broker-dealers and between broker-dealers and their costumers." (LOSS, Louis. Fundamentals of Securities Regulations. Boston and Toronto: Little Brown and Company, sem data, pp. 675-676 apud. NETO, Eduardo Salomão. Nova Regulamentação do Mercado de Balcão Organizado. pp. $102-$ 103).

${ }^{80}$ Cf. EIZIRIK, Nelson; GAAL, Ariádna B.; PARENTE, Flávia; HENRIQUES, Marcus de Freitas. Mercado de capitais: regime jurídico. p. 237.
} 
intensificar sua supervisão sob os derivativos de balcão, em especial nos mercados de swaps de crédito.

\section{Contratos a Termo}

A intensificação das trocas econômicas permitiu o surgimento de agentes econômicos destinados ao exercício profissional de atividades comerciais e, portanto, com habitualidade. Nesse cenário, não bastava avaliar a conjuntura existente no momento de cada troca, pois a concorrência com demais agentes exigia uma visão prospectiva dos negócios. Dessa forma, uma série de mecanismos contratuais passou a ser desenvolvida para a proteção do patrimônio dos contratantes frente às incertezas do futuro.

Os contratos a termo estão entre as primeiras estruturas negociais adotadas em face dos riscos de mudança no cenário econômico. A partir da fixação de um preço a ser pago no futuro, comprador se protege de uma elevação no valor de mercado de um bem e, por outro lado, o vendedor resta protegido contra sua desvalorização. Tais contratos são celebrados a partir de negociações diretas entre as partes, sendo instrumentos próprios dos mercados de balcão.

A natureza jurídica desses contratos é de típica compra e venda, embora sua execução esteja prevista para uma data futura (daí a origem da expressão "to-arrive contracts"). E, sendo a compra e venda um contrato consensual, os contratos a termo se tornam obrigatórios e perfeitos no momento em que as partes definem o objeto e o preço, não podendo qualquer delas se recusar unilateralmente a cumprir sua obrigação na data futura (art. 481 do Código Civil). ${ }^{81}$

\footnotetext{
${ }^{81}$ Nesse sentido, é a opinião de Otavio Yazbek, apoiado nas lições de Roberto Quiroga Mosquera. Em outras palavras, Eduardo Salomão Neto adota o mesmo entendimento acerca da natureza jurídica dos contratos a termo (YAZBEK, Otavio. Regulação do Mercado Financeiro e de Capitais. p. 110; e NETO, Eduardo Salomão. Direito Bancário. pp. 333-334).
} 
Entretanto, era possível que, durante o lapso temporal fixado, o preço oscile drasticamente. Diante da falta de padronização desses acordos (sobretudo, a variedade de datas de vencimentos possíveis), restava ao agente assistir impotente à acumulação de suas perdas. E, para se retirar da avença, deveria encontrar alguém que aceitasse sua posição e antecipasse as perdas acumuladas, além de obter a anuência da contraparte. ${ }^{82}$

As partes, então, se sujeitavam a um elevado risco de crédito, tanto pela reduzida possibilidade de abstração da condição financeira de cada contratante, como em razão da ausência de desembolsos iniciais ou intermediários, o que ampliava sua exposição gradualmente. ${ }^{83}$

Por sua vez, a negociação em mercado de balcão também contribuía para o aumento do risco de crédito, dada a ausência de divulgação ampla dos preços. ${ }^{84}$

Além disso, ainda que a efetiva entrega ocorresse, os agentes tinham de suportar os custos e os riscos inerentes ao transporte das mercadorias.

Por sua vez, o surgimento de derivativos financeiros, , principalmente durante a década de 1980, também impulsionou o desenvolvimento dos contratos a termo, tendo em vista a natureza dos ativos financeiros (como índices, taxas de juros ou cambiais), os quais não se sujeitam à entrega física.

\footnotetext{
${ }^{82}$ A explicação é apresentada por Otavio Yazbek, com base na doutrina de Roberto Quiroga Mosquera (YAZBEK, Otavio. Regulação do Mercado Financeiro e de Capitais. p. 112).

${ }^{83}$ Vide LOBO, Carlos Augusto da Silveira. Os mercados de futuros. p. 148; e LOPES, Alexsandro Broedel. Operações com derivativos: uma introdução multidisciplinar e algumas lições da crise no Brasil. Revista de Direito Mercantil. São Paulo: Malheiros, 2009, vol. 148, p. 19.

${ }^{84}$ BESSADA, Octavio; BARBEDO, Claudio; ARAÚJO, Gustavo Silva. Mercado de derivativos no Brasil: conceitos, operações e estratégias. p. 27.
} 


\title{
12. Contratos Futuros
}

A partir das dificuldades encontradas nos contratos a termo, as operações foram cada vez mais se sofisticando com adoção de novos mecanismos negociais, resultando no que, atualmente, denomina-se mercado de futuros.

A negociação em ambiente de bolsa, reunindo diversos participantes, representou um dos grandes avanços nessas contratações, na medida em que permitiu uma maior visibilidade dos preços e a atração do capital de risco dos especuladores, proporcionando uma maior liquidez. ${ }^{85}$

Em resposta à impossibilidade de entrega dos ativos financeiros e aos custos e riscos decorrentes da entrega física das mercadorias, o mercado adotou um forma de pagamento específica: a liquidação por diferença, realizada a partir da comparação entre o preço contratual e o preço de mercado na data de vencimento, o que implica, consequentemente, na transferência entre agentes do montante financeiro representativo dessa diferença. De acordo com Eduardo Salomão Neto:

\begin{abstract}
"Isso se dá em virtude da lógica econômica de que o ativo alienado terá de ser adquirido pela parte obrigada a sua venda no mercado, e revendido à parte adquirente, que por sua vez poderá imediatamente revendê-lo de novo por preços de mercado." 86
\end{abstract}

\footnotetext{
${ }^{85}$ A atração de capital de risco pelos mercados futuros é destacada por Otavio Yazbek, citando Marco Aurélio Teixeira. Já a visibilidade de preços é bem explicada por Octavio Bessada et al. nos seguintes termos: "A utilização do mercado futuro de uma determinada mercadoria ou ativo financeiro para a formacão de seu preco no mercado à vista é o que se chama de visibilidade de preço. Os preços futuros refletem a expectativa presente sobre o futuro por parte dos agentes econômicos. Essa expectativa não é rígida, pois os mercados são dinâmicos e refletem as alterações dos fatores que formam os preços. Qualquer nova informação ou avaliação sobre as condições de oferta e procura da mercadoria ou ativo financeiro feita pelo mercado é imediatamente transferida aos preços futuros. A facilidade de entrada e saída nos mercados futuros alarga o potencial de competitividade dos preços futuros, com reflexos diretos sobre os preços à vista. Os precos assim formados representam informacão importante para o processo de tomada de decisão nas economias de mercado. Até o governo infere tendências e expectativas dos mercados através da observação dos preços futuros, relevantes para a formação da política econômica." (grifos nossos) (YAZBEK, Otavio. Regulação do Mercado Financeiro e de Capitais. p. 112; e BESSADA, Octavio; BARBEDO, Claudio; ARAÚJO, Gustavo Silva. Mercado de derivativos no Brasil: conceitos, operações e estratégias. p. 43).
}

${ }^{86}$ NETO, Eduardo Salomão. Direito Bancário. p. 334. 
Além disso, os contratos sofreram um processo de padronização, permitindo a circulação de seus direitos e obrigações como bens fungíveis, na forma de itens de pregão. As "unidades negociáveis padronizadas" denominadas de "contratos" passaram a ser compradas e vendidas no lugar dos próprios ativos subjacentes, sendo tais posições registradas em nomes dos participantes. ${ }^{87}$

Outro mecanismo fundamental para o desenvolvimento dos mercados futuros foi a criação de câmaras ou caixas de liquidação $e$ compensação (Clearing Houses). Assim, as contratações puramente bilaterais passaram a contar com uma contraparte central, que se responsabilizava pela liquidação das obrigações frente a cada parte. Como veremos posteriormente, em vista dos riscos acumulados por essas entidades, uma série de estruturas garante sua capacidade de solvência. Entre elas, podemos destacar a técnica de marcação a mercado e os consequentes ajustes diários, a exigência de prestação de garantias pelas partes, além da existência de patrimônio especial nessas instituições.

A partir das características acima, a natureza jurídica desses contratos se tornou controvertida. A posição majoritária entende que os mecanismos incorporados aos contratos futuros não os descaracterizam da compra e venda. ${ }^{88}$

Já em linha parcialmente divergente, Otavio Yazbek sustenta que tal entendimento seria até adequado aos contratos futuros de mercadorias, porém "flagrantemente insustentável nos financial futures" (grifos originais). Segundo o autor, considerando-se um futuro de câmbio, uma

\footnotetext{
${ }^{87}$ Cf. LOBO, Carlos Augusto da Silveira. Os mercados de futuros. p. 149; e YAZBEK, Otavio. Regulação do Mercado Financeiro e de Capitais. p. 113.

${ }^{88}$ De acordo com Otavio Yazbek, são partidários dessa corrente Rachel Sztajn, Roberto Quiroga Mosquera e Marcos Paulo de Almeida Salles. No mesmo sentido parece se orientar Eduardo Salomão Neto, ao abordar a liquidação por diferença: "A compra e venda não é no caso utilizada para sua finalidade econômica típica, mas não se descaracteriza por isso, segundo a clássica lição de Tullio Ascarelli sobre o que chamou de negócios jurídicos indiretos" (YAZBEK, Otavio. Regulação do Mercado Financeiro e de Capitais. p. 117; e NETO, Eduardo Salomão. Direito Bancário. pp. 334-335).
} 
compra e venda de moeda estrangeira não poderia ser realizada entre pessoas físicas ou entre pessoas jurídicas não-financeiras (salvo exceções), de acordo com as normas do Banco Central do Brasil. Já em se tratando de futuros de taxa de juros e de índice de ações, não raro os objetos são impossíveis para a compra e venda, inclusive por motivos lógicos. No mais das vezes, a suposta compra e venda envolveria bens de negociação restrita ou impossível, o que tornaria o negócio jurídico invalido por força do art. 104, II, do Código Civil. Nessa linha, conclui o autor pela "artificialidade da imposição da categoria 'compra e venda' a todos os futuros", de modo que os futuros financeiros devam ser entendidos como contratos inominados ou atípicos. ${ }^{89}$

\section{Opções}

A opção é o negócio mediante o qual um agente adquire o direito de comprar de (ou vender a) outro agente um determinado ativo no futuro por um valor prefixado.

Sua lógica econômica pode ser encontrada em uma série de instrumentos como ocorre no leasing e na compra e venda a contento, assim como nos difundidos planos de opção de compra de ações (stock option plans) previstos no Art. $168, \S 3^{\circ}$, da Lei ${ }^{\circ} 6.404 / 76 .^{90}$

Contudo, as análises depreendidas abaixo são concentradas nas opções negociadas de forma autônoma nos mercados de bolsa e balcão, motivo pelo qual a extensão dessas explicações a instrumentos, que, por exemplo, contenham opções embutidas (embedded options), deve estar atenta à necessidade de eventuais adaptações.

$\mathrm{O}$ adquirente de uma opção é conhecido como titular ou comprador, enquanto o agente que outorga a opção é denominado lançador ou vendedor. Além disso, podemos encontrar opções baseadas em uma

\footnotetext{
${ }^{89}$ Cf. YAZBEK, Otavio. Regulação do Mercado Financeiro e de Capitais. p. 117.

${ }^{90}$ Cf. SZTAJN, Rachel. Sobre a natureza jurídica das opções negociadas em bolsas. p. 53.
} 
variedade de ativos subjacentes (ações, taxas, índices, mercadorias, cotas de fundo, etc). O valor prefixado para a aquisição do ativo é denominado preço de exercício (strike price ou exercise price) e a data futura para exercício ou não da opção é chamada de data de vencimento (expiration date).

A diferença fundamental entre as opções e os contratos a termo reside no fato de que o titular de uma opção possui um direito e nãa uma obrigação de comprar ou vender em uma data futura. Logo, poderá simplesmente optar por exercer ou não esse direito, não estando sequer obrigado a justificar sua escolha. ${ }^{91}$ Como contraprestação a esse direito, o adquirente da opção normalmente paga uma quantia ao lançador quando a operação é celebrada, conhecida como prêmio. O titular da opção, então, suporta o risco de perda do prêmio, enquanto o lançador se sujeita a um risco indeterminado. ${ }^{92}$

A opção pode conferir ao seu titular um direito de compra (call option) ou um direito de venda (put option) e tal direito pode ser exercido até a data de vencimento (opção do tipo europeia) ou somente na data de vencimento (opção do tipo americana). ${ }^{93}$ Além disso, as opções podem ser padronizadas, como ocorre com as opções negociadas em bolsa e balcão em

\footnotetext{
${ }^{91}$ Cf. SZTAJN, Rachel. Sobre a natureza jurídica das opções negociadas em bolsas. p. 55.

92 Cf. SQUASSONI, Christian Max Finardi. Riscos operacionais nos mercados de futuros, opções $e$ de swaps na Bolsa de Mercadorias e Futuros - BM\&F. Revista de Direito Mercantil. São Paulo: Malheiros, 2000, vol. 120, p. 244. Entendendo tratar-se a opção de contrato preliminar, Eduardo Salomão Neto apresenta interessantes ponderações sobre o prêmio. Inicialmente, destaca que o prêmio seria devido apenas em razão da promessa de contratar de maneira definitiva no futuro, não representando este pagamento acessório com natureza de arras ou cláusula penal. Assim, prossegue o autor enumerando as seguintes consequências jurídicas: (i) não pode ser retido, salvo estipulação em contrário, sob o argumento de que a contratação final não ocorreu (inaplicável, portanto, o art. 476 do Código Civil); (ii) por não representar arras, não deve ser considerado, por exemplo, como princípio de pagamento nos termos do art. 417 do Código Civil, bem como não resulta em alteração no preço de exercício, salvo estipulação diversa em ambos os casos; e (iii) não sendo decorrência de cláusula penal, não se sujeita, por exemplo, à redução equitativa prevista no art. 413 do Código Civil (NETO, Eduardo Salomão. Direito Bancário. pp. 338-339). Em sentido contrário, o professor Luiz Gastão Paes de Barros Leães ressalta uma natureza especial do prêmio: "desempenha esse desembolso inicial a função de arras penitenciais do contrato, mediante as quais é concedida ao titular da opção a faculdade do arrependimento, resilindo o contrato." (grifos nossos) (LEÃES, Luiz Gastão Paes de Barros. Liquidação Compulsória de Contratos Futuros. Revista dos Tribunais. São Paulo: Revista dos Tribunais, 1992, vol. 675, p. 46).
} 
nosso país, ou não-padronizadas (opções flexíveis), tipicamente negociadas em mercados de balcão (embora não no Brasil).

A natureza jurídica das opções é extremamente controversa. A posição majoritária, defendida por doutrinadores como o professor Luiz Gastão Paes de Barros Leães, atribui natureza contratual à opção. Nas palavras desse autor:

\begin{abstract}
"Trata-se, desenganadamente, de um contrato, que não se confunde com o compromisso de compra e venda, pois este se encarta na categoria dos contratos preliminares. (...) Na opção, tanto a parte venditoris quanto a parte emptoris, há um único contrato de compra e venda, cuja execução é não só diferida como condicionada ao eventual aceite do titular da opção. Trata-se de contrato definitivo pendente de uma conditio iuris." (grifos originais) ${ }^{94}$
\end{abstract}

Em linha semelhante, também se orienta a argumentação apresentada

por Pontes de Miranda. De acordo com esse eminente jurista:

\begin{abstract}
"A natureza do contrato de compra-e-venda com opção revela-se em ser bilateral o contrato e haver cláusula de resolução ex nunc, que só atinge a eficácia. $\mathrm{O}$ contrato de compra-e-venda foi concluído. A resolução somente concerne ao adimplemento, que ficou a líbito de um dos figurantes. De modo nenhum atinge a conclusão do contrato. (...) Compra-e-venda houve, a cláusula subordinou a eficácia e em consequência o modo de prestar e de contraprestar à resilição a líbito do comprador, ou do vendedor." (grifos originais) ${ }^{95}$
\end{abstract}

Já a posição minoritária, liderada pela professora Rachel Sztajn, interpreta a opção como negócio jurídico unilateral. Nesta segunda abordagem, Rachel Sztajn identifica uma cláusula potestativa no contrato de opção, o que lhe retiraria a validade nos termos do art. 122 do Código Civil. E, diante dessa constatação, conclui a autora que:

\footnotetext{
${ }^{93}$ Conforme destacado pelo Options Institute, divisão educacional da Chicago Board Options Exchange: "The difference between European-style options and American-style options has nothing to do with geography! The distinguishing feature is the right of early exercise that exists with American options and does not exist with European options." (grifos nossos) (INSTITUTE, Options. Options: essential concepts and trading strategies. $2^{\text {nd }}$ Ed. Illinois: Irwin Professional Publishing, 1995. p. 20).

${ }^{94}$ LEÃES, Luiz Gastão Paes de Barros. Liquidação Compulsória de Contratos Futuros. p. 46.

${ }^{95}$ MIRANDA, Pontes de. Tratado de Direito Privado. $3^{\text {a }}$ Ed. São Paulo: Revista dos Tribunais, 1984, Parte Especial, Tomo LII, p. 282.
} 
"Qualificá-las declaração unilateral e não contrato, com vinculação do declarante e garantindo ao destinatário o privilégio, o direito formativo gerador, de livremente decidir o que melhor lhe convenha, soluciona a dificuldade criada pela cláusula potestativa sem que seja necessário circundá-la com exercícios de ficção." (grifos originais) ${ }^{96}$

A opinião é criticada por Otavio Yazbek, o qual sustenta que (i) não há como negar a natureza contratual da opção, e (ii) ainda que exista uma condição potestativa, esta não seria pura (ou arbitrária), visto que o "direito potestativo" decorre da própria natureza do negócio e a decisão de exercê-lo está vinculada às condições de mercado na data de exercício; aliás, prossegue o autor, o sistema jurídico admite a potestatividade em casos como da compra e venda a contento. Já em relação a outros tipos de opções (por exemplo, os planos de opção de compra de ações), o autor entende que a solução da professora Rachel Sztajn é perfeita. ${ }^{97}$

\section{Swaps}

Os swaps ganharam notoriedade nas décadas de 1970 e 1980, sendo a permuta entre a IBM e o Banco Mundial o contrato mais citado e analisado. A origem dos swaps seriam empréstimos cruzados com troca de moeda entre empresas de países diferentes, como já parecia identificar o art. $4^{\circ}$, XXXI, da Lei $\mathrm{n}^{\circ} 4.595 / 64$, ao atribuir competência para o CMN "baixar normas que regulem as operações de câmbio, inclusive swaps, fixando limites, taxas, prazos e outras condições." (grifos nossos). ${ }^{98}$

Contudo, as feições dos contratos de swaps negociados recentemente, por vezes, os distanciam dos simples mútuos paralelos. Em seu desenho mais contemporâneo, os swaps são definidos pelo professor John Hull como: "acordos privados entre duas empresas para a troca futura

\footnotetext{
${ }^{96}$ SZTAJN, Rachel. Sobre a natureza jurídica das opções negociadas em bolsas. p. 69.

${ }^{97}$ YAZBEK, Otavio. Regulação do Mercado Financeiro e de Capitais. p. 124.

${ }^{98}$ Cf. SZTAJN, Rachel. Futuros e swaps: uma visão jurídica. p. 217-218; e YAZBEK, Otavio. Regulação do Mercado Financeiro e de Capitais. pp. 118-119.
} 
de fluxos de caixa, respeitada uma fórmula preestabelecida". Não há, portanto, substituição das partes que figuram nos acordos subjacentes, apenas se contratando a assunção recíproca de riscos. ${ }^{99}$

Por exemplo, a empresa A tem dívidas referenciadas em uma taxa variável e deseja ter maior previsibilidade e segurança quanto às suas despesas. Já a empresa B possui ativos remunerados por uma taxa fixa e deseja melhorar seu retorno, vinculando o investimento a uma taxa variável. Nesse cenário, as empresas poderão contratar um swap em que A se compromete a entregar à $\mathrm{B}$ o valor da taxa variável aplicada sobre um dado principal (conhecido como valor nocional) e B se obriga a pagar o valor da taxa fixa aplicada sobre esse principal.

Uma das principais funções dos swaps é modificar os fluxos de caixa decorrentes dos ativos subjacentes. As partes visam a transformar suas obrigações perante terceiros, sem precisar alterá-las em si. Além disso, os swaps proporcionam maior vantagem do que outras operações destinadas ao mesmo resultado econômico. Assim, entende-se que essa categoria de derivativos provoca uma redução de risco e de custo financeiro. ${ }^{100}$

As operações são normalmente realizadas em mercado de balcão, do que resultam suas inúmeras estruturas contratuais, mais recentemente sujeitas a esforços de sistematização por parte de instituições como a ISDA. Em regra, são realizadas a longo prazo e não exigem desembolso inicial, embora sejam submetidas a verificações intermediárias em intervalos superiores aos praticados nos contratos futuros, os quais se liquidam diariamente. $^{101}$

\footnotetext{
${ }^{99}$ YAZBEK, Otavio. Regulação do Mercado Financeiro e de Capitais. pp. 118 e 119.

${ }^{100}$ Cf. SZTAJN, Rachel. Futuros e swaps: uma visão jurídica. pp. 224-225; e FILHO, Arnoldo Wald; ANTUNES, Mariana Tavares; GAENSLY, Marina. Contratos de swap (...). Revista de Direito Bancário e do Mercado de Capitais. São Paulo: Revista dos Tribunais, 2005, vol. 28, p. 311.

${ }^{101}$ YAZBEK, Otavio. Regulação do Mercado Financeiro e de Capitais. p. 121; SZTAJN, Rachel. Futuros e swaps: uma visão jurídica. p. 234; e TALAVERA, Glauber Moreno. Aspectos Elementares do Hedging. p. 203. Este último autor destaca que a desnecessidade de recursos no início da operação de swap explica porque são conhecidas como "hedge sem caixa".
} 
A natureza jurídica dos swaps também não é pacífica, inclusive porque a expressão não se aplica a um único instrumento, mas a um gênero que, não raro, envolve operações bem distintas. ${ }^{102}$

A maioria da doutrina se aproxima da troca ou permuta. Por exemplo, é essa a opinião da professora Rachel Sztajn, vejamos:

"Nos países de sistema anglo-norte-americano, os contratos são permutas de fluxos de caixa e, dessa forma, devem ser qualificados também no Brasil. Permuta atípica, a que não se aplicam as regras de compra e venda nem subsidiariamente, mas que se rege pelas características gerais do contrato bilateral, oneroso e, por vontade das partes, aleatório, de execução diferida e parcelada. Somam-se à permuta regras de conota corrente mercantil que se referem à apuração da diferença a cada termo (parcial) do contrato de execução continuada." (grifos nossos) ${ }^{103}$

Já em posição oposta, Ari Cordeiro Filho entende o swap como um contrato nominado, com referências expressas a sua figura na legislação tributária (Lei no 8.981/95) e bancária (Lei no 4.595/64). Segundo o autor, a troca mercantil seria um contrato diferenciado do swap, embora lhe forneça elementos integrativos. ${ }^{104}$

Uma terceira linha, defendida por autores como Otavio Yazbek e Roberto Quiroga Mosquera, entende que os swaps são contratos inominados, dada a ausência de tipificação na legislação em vigor. ${ }^{105}$ Nesse sentido, também se orienta a professora Judith Martins-Costa em parecer

\footnotetext{
${ }^{102}$ A observação é apresentada por Otavio Yazbek, com base nas lições de Francesco Caputo Nassetti (YAZBEK, Otavio. Regulação do Mercado Financeiro e de Capitais. p. 118).

${ }^{103}$ SZTAJN, Rachel. Futuros e swaps: uma visão jurídica. p. 229.

${ }^{104}$ FILHO, Ari Cordeiro. Swaps - aspectos jurídicos. Revista de Direito Bancário e do Mercado de Capitais. São Paulo: Revista dos Tribunais, 2001, vol. 11, p. 68.

${ }^{105}$ Cf. YAZBEK, Otavio. Regulação do Mercado Financeiro e de Capitais. p. 121. Também encontramos referência à atipicidade dos swaps na interessante petição inicial da autoria de Arnoldo Wald Filho, Mariana Tavares Antunes e Marina Gaensly, publicada na Revista de Direito Bancário e do Mercado de Capitais, da qual transcrevemos a passagem abaixo: "Em vista do exposto, pode-se dizer que o swap é um contrato atípico, oneroso, personalíssimo, de trato sucessivo e aleatório. Mas é preciso deixar explicitado, sobretudo, que o swap é um contrato essencialmente bilateral e sinalagmático." (grifos originais) (FILHO, Arnoldo Wald; ANTUNES, Mariana Tavares; GAENSLY, Marina. Contratos de swap (...).p. 312).
} 
publicado na Revista de Direito Bancário e do Mercado de Capitais, contendo o seguinte trecho:

\begin{abstract}
"Em face da regra do art. 425 do CC/2002, c/c a do art. 112 do CC/2002, e da regra hermenêutica da analogia (pela qual, em face de um contrato atípico e de um contrato misto, aplica-se, supletivamente à vontade declarada das partes, a disciplina do tipo contratual que lhe é mais próximo) aos contratos de swap se aplicam as regras previstas imediatamente para a troca e, mediatamente, para a compra e venda (art. 533 do CC/2002)." (grifos originais) ${ }^{106}$
\end{abstract}

Registramos, por fim, a explicação apresentada por Eduardo Salomão Neto, para quem um conjunto de negócios jurídicos se presta a operacionalizar a finalidade econômica de troca presente em um swap: (i) o

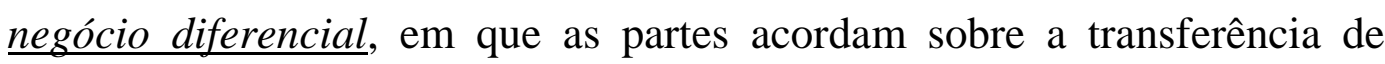
fluxo financeiro resultante da liquidação por diferença do valor de suas obrigações; (ii) o reporte, em que se compra títulos representativos de valor à vista, com simultânea retrocessão a termo; e (iii) os mútuos cruzados, em que agentes com obrigações ajustadas por taxas distintas reemprestam um ao outro os recursos com as mesmas taxas que receberam. ${ }^{107}$

Em conclusão da análise dos swaps, destacamos uma modalidade negocial que, embora submetida às explicações acima, merece tratamento especial por sua relevância no universo dos derivativos, notadamente após a crise internacional de 2008.

O surgimento dos derivativos de crédito, centrados na figura dos swaps, resulta de normas de ponderação e de adequação do patrimônio das instituições financeiras a partir da década de 1990. Como maneira de contornar essas restrições, as instituiçõos financeiras passaram a transferir seu risco de crédito a terceiros, o que permitia a realização de mais empréstimos. $^{108}$

\footnotetext{
${ }^{106}$ MARTINS-COSTA, Judith. Contratos de Derivativos Cambiais. Contratos Aleatórios. Abuso de Direito e Abusividade Contratual. Boa-fé objetiva (Parecer). p. 328.

${ }^{107}$ NETO, Eduardo Salomão. Direito Bancário. pp. 326-327.

${ }^{108}$ Cf. YAZBEK, Otavio. O risco de crédito e os novos instrumentos financeiros - uma análise funcional. p. 330.
} 
A lógica envolvida nesses instrumentos é de que as partes negociem o risco de crédito de certa operação, sem transferir o ativo subjacente que dá origem a esse risco. Por exemplo, no caso de um credit default swaps, a transferência do risco de crédito decorre da obrigação da parte receptora de recompor, total ou parcialmente, o valor de referência previsto no contrato quando configurado um evento de deterioração de crédito, conforme seja definido pelas partes. ${ }^{109}$

A alta concentração desses instrumentos em determinados agentes resultou em perdas sensíveis durante a crise internacional de 2008 e, especialmente no Brasil, acendeu o debate sobre a possibilidade de revisão desses acordos com base na Teoria da Imprevisão. Assim, sua plena compreensão representa uma necessidade para o desenvolvimento de um regime jurídico seguro e adequado aos derivativos.

\section{Os Mercados de Derivativos no Brasil}

No Brasil, as negociações com derivativos ocorrem nos mercados de bolsa e balcão organizado administrados pela BM\&FBovespa S.A. - Bolsa de Valores, Mercadorias e Futuros ("BM\&FBovespa"), e no mercado de balcão organizado administrado pela CETIP S.A. - Mercados Organizados

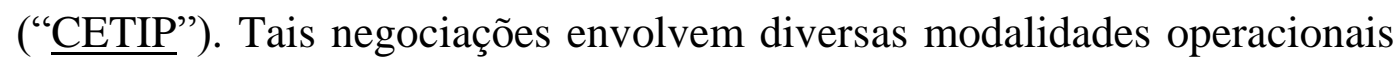
e estão sujeitas à autorregulação exercida pelas entidades acima, em complemento à regulação imposta pela própria CVM.

A BM\&FBovespa dispõe de uma câmara destinada à compensação, liquidação e ao gerenciamento dos riscos das operações de derivativos (isto é, desenvolvendo as funções de Clearing). Uma das principais funções dessa câmara é atuar como contraparte central, assumindo a

\footnotetext{
${ }^{109}$ No Brasil, a matéria é disciplina pela Resolução CMN n ${ }^{\circ} 2.933 / 02$ e pela Circular BCB no 3.106/02. Para um maior aprofundamento no assunto, remetemos o leitor aos artigos GOLDSTEIN, Sergio Mychkis. Aspectos jurídicos dos derivativos de crédito no Brasil. p. 63, e YAZBEK, Otavio. O risco de crédito e os novos instrumentos financeiros - uma análise funcional. pp. 309-337.
} 
responsabilidade sobre a liquidação de todas as operações realizadas nos mercados de bolsa ou balcão na modalidade garantida. $\mathrm{O}$ mercado brasileiro não possui outras Clearings de derivativos com a função de contraparte central, sendo muito debatida atualmente a necessidade de criação de um novo agente, em especial para os derivativos de balcão.

Como veremos posteriormente, as Clearings de derivativos desempenham um papel fundamental no funcionamento do mercado financeiro, contribuindo diretamente para sua solidez. Entretanto, uma compreensão adequada dessas entidades demanda que, antes, seja analisado um panorama geral dos sistemas de pagamentos e, em especial, o processo de liquidação e compensação, temas tratados a seguir, na Segunda Parte deste estudo.

\section{SEGUNDA PARTE - NOÇÕES FUNDAMENTAIS DE SISTEMAS DE PAGAMENTOS}

\section{Capítulo IV - Os Sistemas de Pagamentos e sua Importância na Economia}

\section{Economia de Mercado e Moeda}

Na antiguidade e na Idade Média, as sociedades possuíam economias fechadas e tipicamente de subsistência. Os bens se destinavam principalmente ao consumo dos grupos familiares, seus agregados e servos, enquanto as trocas se restringiam aos excedentes. Já nas unidades artesanais e de ofício da Idade Média, a produção não se destinava ao consumo próprio, porém apenas supria encomendas pontuais, valendo-se de uma estrutura com baixo grau de especialização e reduzida divisão de trabalho. A troca de bens já era negociada em mercados, embora intermitentes, isolados, envolvendo pequena quantidade de produção e restrita parcela da população. 
Sobretudo, em razão do impulso gerado pela Revolução Industrial, chegou-se ao sistema econômico de mercado, fundado nas relações de trocas. As trocas representam uma melhor forma de alocação eficiente dos bens e serviços, assim como permitem a maior especialização e, por conseguinte, um ganho de produtividade. Porém, a grande inovação desse sistema é a interligação entre os mercados, os quais passam a ter funcionamento permanente e participação de toda a população. A maioria das pessoas deixa de produzir para o consumo próprio e passa a integrar unidades coletivas de produção (as empresas), adquirindo no mercado os bens de que necessita. ${ }^{110}$

Entretanto, uma economia baseada exclusivamente na troca de bens enfrenta uma série de custos e dificuldades, visto que um agente deverá encontrar alguém que deseje adquirir certo bem ou serviço e ainda possa lhe oferecer uma contrapartida adequada. Os efeitos negativos da necessidade de satisfação recíproca de interesses são descritos com clareza pelo professor Frederic Mishkin:

\begin{abstract}
"Take the case of Ellen the Economics Professor, who can do just one thing well: give brilliant economics lectures. In a barter economy, if Ellen wants to eat, she must find a farmer who not only produces the food she likes but also wants to learn economics. As you might expect, this search will be dificult and timeconsuming, and Ellen might spend more time looking for such an economicshungry farmer than she will teaching. It is even possible that she will have to quit lecturing and go into farming herself. Even so, she may starve to death." ${ }^{111}$
\end{abstract}

Aos poucos, a simples troca se repartiu em duas unidades funcionais: embora se mantenha a estrutura de permuta de um bem por outro, esse outro bem passa a ser utilizado tão somente como instrumento para facilitar uma troca futura. $\mathrm{O}$ agente econômico pode aceitar determinado bem, ainda

\footnotetext{
${ }^{110}$ Cf. LAMY FILHO, Alfredo; BULHÕES PEDREIRA, José Luiz. A lei das S.A.: pressupostos, elaboração, aplicação. Rio de Janeiro: Renovar, 1997, vol. I. pp. 45-47; e NUSDEO, Fábio. Curso

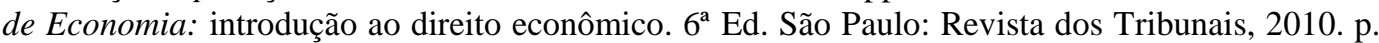
45 .

${ }^{111}$ MISHKIN, Frederic S. The economics of money, banking, and financial markets. $7^{\text {th }}$ Ed. Massachusetts: Addison-Wesley, 2004. p. 45.
} 
que não o utilize para seu consumo, pois tem certeza de sua aceitação em uma troca posterior. Nasce, assim, a ideia de uma moeda. ${ }^{112}$

Inicialmente, os bens mais preciosos desempenharam a função típica da moeda: servir de instrumento de troca. Na medida em que poderiam ser utilizados novamente, tais bens também armazenavam um poder de compra - ou seja, possuíam uma reserva de valor. E, ainda, como os negócios passaram a ser intermediados por esses bens, estabeleceu-se naturalmente uma razão de troca entre eles e todos os demais (denominada de preço). Assim, tais bens se tornaram parâmetro universal para as trocas, funcionando como unidade de conta.

A partir daí, a moeda assumiu as mais diferentes formas e espécies sempre com vistas a maior portabilidade, segurança, celeridade nas transferências, além da prevenção a fraudes e falsificações. Nessa linha evolutiva, os custos e riscos do transporte de altas quantias levaram comerciantes a entregar tais valores a outros comerciantes com maiores e melhores instalações para que posteriormente fossem retiradas mediante a apresentação de um recibo em papel. Os recibos, por sua vez, passaram a circular no lugar da moeda, reduzindo-se cada vez mais os resgates. Dessa forma, surgem o papel-moeda e as próprias raízes da atividade bancária.

No sentido da desmaterialização, o papel-moeda foi gradualmente se descolando de seu lastro metálico, elemento antes legitimador de sua circulação. Sua emissão por bancos privados converteu-se em monopólio do Estado, passando este a impor sua obrigatoriedade como meio de pagamento (conhecida como curso legal ou curso forçado). Um novo ciclo de fraudes, acompanhado pelos desenvolvimentos tecnológicos, propulsionou ainda mais sua desmaterialização, podendo atualmente ser representado por um mero lançamento de disponibilidade de recursos em um sistema de registros. ${ }^{113}$

\footnotetext{
${ }^{112}$ Cf. NUSDEO, Fábio. Curso de Economia: introdução ao direito econômico. pp. 48-49.

${ }^{113}$ Cf. Ibid., pp. 51-52.
} 
Passa a ser considerado dinheiro, em qualquer de suas múltiplas formas, o elemento que é aceito universalmente em pagamentos de bens, serviços ou dívidas. ${ }^{114}$

\section{O Papel dos Sistemas de Pagamentos na Economia em Geral}

A interação na vida econômica dá origem a inúmeros vínculos jurídicos temporários entre agentes, conhecidos como obrigações. O próprio estabelecimento dessas conexões por período limitado já pressupõe a realização de operação inversa no futuro, em que os agentes irão se desvincular. ${ }^{115}$

O pagamento é uma forma de extinção de obrigações por meio de seu cumprimento, operando em última análise a desvinculação entre os agentes. Nas obrigações de natureza pecuniária, o pagamento se configura pela transferência de dinheiro do devedor ao credor, o que pode ser realizado de diversas maneiras.

A entrega de dinheiro em espécie é o meio mais tradicional de pagamento, sobretudo para operações de pequeno valor. Além disso, os pagamentos em dinheiro físico não são registrados no sistema bancário, o que justifica sua demanda na economia informal. ${ }^{116}$ As principais vantagens dessa forma de pagamento são a segurança e a celeridade na transferência do dinheiro, embora os custos envolvidos em seu transporte e guarda prejudiquem sua utilização em operações de maior valor.

Em operações de elevado valor, a escolha do meio de pagamento assume considerável relevância, dada sua repercussão direta nos custos e riscos. Na linha de desmaterialização da moeda, as transferências

\footnotetext{
${ }^{114}$ Cf. MISHKIN, Frederic S. The economics of money, banking, and financial markets. p. 44.

${ }^{115}$ Cf. PEREIRA, Caio Mário da Silva. Instituições de Direito Civil. 21 a Ed. Rio de Janeiro: Editora Forense, 2008, vol. II. p. 191.

116 Cf. PINGITZER, Jürgen C.; SUMMERS, Bruce J. Small-Value Transfer Systems. In: SUMMERS, Bruce J. (editor). The Payment System: Design, Management, and Supervision. International Monetary Fund: Washington, D.C., 1994, p. 108.
} 
eletrônicas de fundos ganharam importância como principal forma de liquidação de obrigações de grande valor, sobretudo em razão da segurança e agilidade que proporcionam.

Um sistema de pagamentos é um conjunto de instrumentos, procedimentos e regras para a transferência de fundos entre ou pelos seus participantes (os quais integram esse arranjo, junto com a entidade que o opera). ${ }^{117} \mathrm{~A}$ expressão também é empregada em acepção mais ampla para se referir a um sistema de pagamentos nacional, como destacado pelo Bank for International Settlements:

"A national payment system is the configuration of diverse institutional arrangements and infrastructures that facilitates the transfer of monetary value between the parties (...)" 118

Os sistemas de pagamentos desempenham papel fundamental no funcionamento de uma economia de mercado, na medida em que as trocas econômicas dependem da eficiência e segurança assegurados pelo processo de transferência dos recursos financeiros. ${ }^{119}$ Nesse sentido, a Resolução ${ }^{\circ}$ 2.882/01 do Banco Central do Brasil estabeleceu, em seu art. $1^{\circ}$, que: “(...) o sistema de pagamentos deve ser estruturado segundo princípios que assegurem sua eficiência, segurança, integridade e confiabilidade" (grifos nossos).

Meios de pagamento lentos, não confiáveis e caros podem reduzir a atividade empresarial e retardar o desenvolvimento de mercados financeiros

\footnotetext{
${ }^{117}$ SETTLEMENTS, Bank for International; COMMISSIONS, International Organization of Securities. Principles for financial markets infrastructures (April 2012, p. 8). Disponível em <http://www.bis.org/publ/cpss101.htm>. Acesso em 22 de setembro de 2012.

${ }^{118}$ SETTLEMENTS, Bank for International. General guidance for national payment system development (January 2006, p. 7). Disponível em <http://www.bis.org/publ/cpss70.htm>. Acesso em 22 de setembro de 2012. No Brasil, a Lei $n^{\circ} 10.214 / 01$ adotou o sentido mais amplo ao prever que: "Art. $2^{\mathrm{o}} \mathrm{O}$ sistema de pagamentos brasileiro de que trata esta Lei compreende as entidades, os sistemas e os procedimentos relacionados com a transferência de fundos e de outros ativos financeiros, ou com o processamento, a compensação e a liquidação de pagamentos em qualquer de suas formas. (...)"

${ }^{119}$ Cf. SUMMERS, Bruce J. The Payment System in a Market Economy. In: SUMMERS, Bruce J. (editor). The Payment System: Design, Management, and Supervision. p. 1.
} 
com liquidez. A ineficiência ainda afeta diretamente os níveis de produção e circulação de bens e serviços. Em economias com altos índices de inflação, a lentidão e falta de confiança nos mecanismos de pagamento também pode agravar o "custo inflacionário" implícito no uso do dinheiro. Existe, portanto, uma conexão direta entre a atividade econômica e os sistemas de pagamentos. ${ }^{120}$

\section{O Papel dos Sistemas de Pagamentos na Estabilidade Financeira e na Política Monetária}

O funcionamento adequado dos sistemas de pagamento também tem repercussão direta na estabilidade financeira nacional e internacional, assim como desperta importantes questões de política monetária (como a disponibilidade de moeda e crédito na economia). Aliás, os sistemas de pagamentos têm características de bem público, o que demanda certo nível de supervisão oficial, além da autorregulação. ${ }^{121}$ Como destacado por Spindler e Summers:

\footnotetext{
"An efficient financial system that engenders public confidence owing to its safety and stability is critical to the perfomance of the real economy. Without efficiency and public confidence in the payment system, even the simplest and most routine financial transactions may become agonizingly difficult." ${ }^{, 22}$
}

Nesse contexto, os Bancos Centrais assumem posição central na regulação e administração desses sistemas. Por exemplo, é universalmente aceito que a liquidação final interbancária deve ser realizada com recursos disponíveis em contas administradas pelo Banco Central (conhecidas no Brasil como reservas bancárias), dada a qualidade singular dessa entidade

\footnotetext{
${ }^{120}$ Cf. MARQUARDT, Jeffrey C. Payment System Policy Issues and Analysis. In: SUMMERS, Bruce J. (editor). The Payment System: Design, Management, and Supervision. p. 119.

${ }^{121}$ Cf. SUMMERS, Bruce J. The Payment System in a Market Economy. p. 5.

${ }^{122}$ SPINDLER, J. Andrew; SUMMERS, Bruce J. The Central Bank and the Payment System. In: SUMMERS, Bruce J. (editor). The Payment System: Design, Management, and Supervision. International Monetary Fund: Washington, D.C., 1994, p. 164.
} 
como agente que não oferece riscos de crédito ou liquidez aos seus correntistas. Em contrapartida, o Banco Central estabelece condições e exigências (como a manutenção de um mínimo de reservas, a manutenção de níveis de liquidez adequados, etc), o que se traduz em um importante instrumento de política monetária. ${ }^{123}$

A possibilidade de extensão de crédito pelo Banco Central, por sua vez, também contribui significativamente para a eficiência dos sistemas de pagamento na medida em que garante as liquidações em tempo quando os bancos apresentam crises de liquidez - desempenhando a função conhecida como de emprestador de última instância (lender of last resort). ${ }^{124}$

Assim, o Banco Central deve dispor de poderes adequados, incluindo a capacidade de obter informações e poderes para induzir mudanças e corrigir ações, além de recursos suficientes e proteções legais apropriadas aos seus agentes. ${ }^{125}$

\section{Recomendações Internacionais para Sistemas de Pagamentos}

Em vista da importância do mercado financeiro para as economias atuais, evidenciada sobretudo pelas crises mais recentes, o Bank for International Settlements (BIS), em cooperação com a International Organization of Securities Commissions (IOSCO), publicou em abril de 2012 um estudo que consolida as recomendações internacionais para as

\footnotetext{
${ }^{123}$ Cf. SUMMERS, Bruce J. The Payment System in a Market Economy. p. 5; e BERGH, Paul Van den. Operational and Financial Structure of the Payment System. In: SUMMERS, Bruce J. (editor). The Payment System: Design, Management, and Supervision. p. 34.

${ }^{124}$ Cf. BLOMMSTEIN, Hans J.; SUMMERS, Bruce J. Banking and the Payment System. In: SUMMERS, Bruce J. (editor). The Payment System: Design, Management, and Supervision. p. 23; BERGH, Paul Van den. Operational and Financial Structure of the Payment System. p. 34.

${ }^{125}$ De acordo com a "Responsibility B" apresentada no estudo SETTLEMENTS, Bank for International; COMMISSIONS, International Organization of Securities. Principles for financial markets infrastructures (April 2012, pp. 128-129). Disponível em <http://www.bis.org/publ/cpss101.htm>. Acesso em 22 set. 2012.
} 
denominadas Financial Market Infrastructures - FMIs ("Infraestruturas do Mercado Financeiro"), definidas singularmente como:

"a multilateral system among participating institutions, including the operator of the system, used for the purposes of clearing, settling, or recording payments, securities, derivatives, or other financial transactions" 126

Os sistemas de pagamento (em sua acepção mais restrita) são tratados no referido estudo como uma espécie de Infraestrutura do Mercado Financeiro e, portanto, as considerações apresentadas merecem abordagem neste estudo.

De acordo com esse documento, as Infraestruturas do Mercado Financeiro, de uma forma geral, têm como seus principais riscos:

(i) risco de crédito, entendido como o risco de uma contraparte não ser capaz de cumprir suas obrigações financeiras quando devidas ou em qualquer momento no futuro;

(ii) risco de liquidez, entendido como o risco de uma contraparte não dispor de recursos suficientes para cumprir suas obrigações financeiras como e quando devidas, embora possa ser capaz de satisfazê-las no futuro;

(iii) risco sistêmico, entendido como o risco de que a incapacidade de um ou mais agentes em cumprir suas obrigações possa se refletir na incapacidade de outros agentes cumprirem suas obrigações quando devidas;

(iv) risco legal, entendido como o risco de uma aplicação imprevista de lei ou regulamento, normalmente resultando em perda, podendo surgir também quando a aplicação da legislação é incerta;

(v) risco do negócio em geral, entendido como o risco de deterioração da condição financeira da Infraestrutura do Mercado

\footnotetext{
${ }^{126}$ SETTLEMENTS, Bank for International; COMMISSIONS, International Organization of Securities. Principles for financial markets infrastructures (April 2012, p. 7). Disponível em $\langle$ http://www.bis.org/publ/cpss101.htm〉. Acesso em 22 set. 2012. O documento substitui três estudos internacionais anteriores: (1) Core principles for systemically important payment systems; (2) Recommendations for securities settlement systems; e (3) Recommendations for central counterparties.
} 
Financeiro, considerada como uma entidade destinada à atividade empresarial (business enterprise). Não se incluem nesse risco, as perdas decorrentes de inadimplência de um agente econômico, incluindo outra Infraestrutura do Mercado Financeiro;

(vi) riscos de custódia e investimento, podendo afetar os ativos detidos pela própria Infraestrutura do Mercado Financeiro ou os ativos que esta detém em nome de terceiros, (a) o risco de custódia é entendido como o risco de perda de ativos custodiados em razão da insolvência, negligência, fraude, administração precária ou registros inadequados, e (b) o risco de investimento é entendido como o risco de perda associado aos investimentos que a Infraestrutura do Mercado Financeiro realiza com seus ativos ou os ativos de seus participantes (como garantias); e

(vii) risco operacional, entendido como o risco de redução, deterioração ou interrupção dos serviços prestados por uma Infraestrutura do Mercado Financeiro, em razão de deficiências nos sistemas informacionais ou nos procedimentos internos, erros humanos, falhas de administração ou perturbações causadas por eventos externos. ${ }^{127}$

Diante dos riscos que afetam a atividade de uma Infraestrutura do Mercado Financeiro e pressupondo sua importância sistêmica para o país onde está localizada, o estudo apresenta uma série de princípios ou recomendações internacionalmente aceitos como parâmetros mínimos de segurança e eficiência. Destacamos abaixo um panorama geral dos princípios que assumem maior relevância na regulação dos sistemas de pagamento:

\footnotetext{
${ }^{127}$ Cf. SETTLEMENTS, Bank for International; COMMISSIONS, International Organization of Securities. Principles for financial markets infrastructures (April 2012, pp. 18-20). Disponível em <http://www.bis.org/publ/cpss101.htm〉. Acesso em 22 set. 2012.
} 


\title{
"Credit and liquidity risk management
}

\author{
Principle 4: Credit risk
}

An FMI should effectively measure, monitor, and manage its credit exposures to participants and those arising from its payment, clearing, and settlement processes. An FMI should maintain sufficient financial resources to cover its credit exposure to each participant fully with a high degree of confidence. In addition, a CCP [central counterparty] that is involved in activities with a morecomplex risk profile or that is systemically important in multiple jurisdictions should maintain additional financial resources sufficient to cover a wide range of potential stress scenarios that should include, but not be limited to, the default of the two participants and their affiliates that would potentially cause the largest aggregate credit exposure to the CCP in extreme but plausible market conditions. All other CCPs should maintain additional financial resources sufficient to cover a wide range of potential stress scenarios that should include, but not be limited to, the default of the participant and its affiliates that would potentially cause the largest aggregate credit exposure to the CCP in extreme but plausible market conditions.

\section{Principle 5: Collateral}

An FMI that requires collateral to manage its or its participants' credit exposure should accept collateral with low credit, liquidity, and market risks. An FMI should also set and enforce appropriately conservative haircuts and concentration limits.

\section{Principle 6: Margin}

A CCP should cover its credit exposures to its participants for all products through an effective margin system that is risk-based and regularly reviewed.

\section{Principle 7: Liquidity risk}

An FMI should effectively measure, monitor, and manage its liquidity risk. An FMI should maintain sufficient liquid resources in all relevant currencies to effect same-day and, where appropriate, intraday and multiday settlement of payment obligations with a high degree of confidence under a wide range of potential stress scenarios that should include, but not be limited to, the default of the participant and its affiliates that would generate the largest aggregate liquidity obligation for the FMI in extreme but plausible market conditions.

\section{Settlement}

\section{Principle 8: Settlement finality}

An FMI should provide clear and certain final settlement, at a minimum by the end of the value date. Where necessary or preferable, an FMI should provide final settlement intraday or in real time.

Principle 9: Money settlements

An FMI should conduct its money settlements in central bank money where practical and available. If central bank money is not used, an FMI should 
minimise and strictly control the credit and liquidity risk arising from the use of commercial bank money.

(...)

\section{Default management}

Principle 13: Participant-default rules and procedures

An FMI should have effective and clearly defined rules and procedures to manage a participant default. These rules and procedures should be designed to ensure that the FMI can take timely action to contain losses and liquidity pressures and continue to meet its obligations.

Principle 14: Segregation and portability

A CCP should have rules and procedures that enable the segregation and portability of positions of a participant's customers and the collateral provided to the CCP with respect to those positions. (...)"(grifos originais) ${ }^{128}$

A análise detalhada de cada princípio demandaria um estudo próprio, razão pela qual remetemos o leitor ao referido estudo para o devido aprofundamento na matéria.

\section{Conceitos e Desenhos Institucionais}

Os sistemas de pagamento envolvem procedimentos adaptados às necessidades de seus participantes e às possibilidades de cada economia. As últimas tendências nos setores comercial, industrial e financeiro tendem a apresentar as novas necessidades, embora toda a gama de participantes (stakeholders) deva ser considerada nas análises e reformas implementadas nesses sistemas. ${ }^{129}$

A partir de tais necessidades, os sistemas de pagamentos se dividiram basicamente em dois modelos: (i) o modelo de transferência de

128 SETTLEMENTS, Bank for International; COMMISSIONS, International Organization of Securities. Principles for financial markets infrastructures (April 2012, pp. 1-2). Disponível em <http://www.bis.org/publ/cpss101.htm>. Acesso em 22 set. 2012.

${ }^{129}$ Cf. SETTLEMENTS, Bank for International. General guidance for national payment system development (January 2006, p. 22). Disponível em <http://www.bis.org/publ/cpss70.htm>. Acesso em 22 set. 2012; e MARQUARDT, Jeffrey C. Payment System Policy Issues and Analysis. pp. 118-119). 
grande valor (large-value payment system); e (ii) o modelo de transferência de pequeno valor (small-value payment system).

Não há critério preciso para se distinguir os dois modelos, embora alguns sistemas sejam tipicamente dedicados a pagamentos de elevado valor, envolvendo um número reduzido de participantes especializados. Assim, os sistemas de pagamento de grandes valores são entendidos como as principais artérias de um sistema de pagamentos nacional, desempenhando papel crucial não apenas nos mercados diretamente atendidos por seus serviços, mas em todo o sistema financeiro de um país. Já os sistemas de pagamentos de pequenos valores podem ser compreendidos como a complexa rede de veias que conecta toda a economia. Normalmente destinados a operações ordinárias, estes sistemas tendem a ser mais versáteis com vistas à liquidação de um elevado número de operações de naturezas distintas e envolvendo virtualmente todos os participantes da economia. ${ }^{130}$

Ambos os modelos são constantemente adaptados as suas respectivas finalidades, sendo tal desenvolvimento canalizado por estruturas e regras internacionalmente aceitas, as quais serão analiticamente apresentadas abaixo. Em vista da íntima conexão entre as estruturas de pagamento e os sistemas de transferência de títulos, as explicações abaixo serão adaptadas, conforme o caso, de maneira a permitir uma compreensão do funcionamento conjunto desses sistemas.

\footnotetext{
${ }^{130}$ Cf. HORII, Akinari; SUMMERS, Bruce J. Large-Value Transfer Systems. In: SUMMERS, Bruce J. (editor). The Payment System: Design, Management, and Supervision. pp. 73-74; PINGITZER, Jürgen C.; e SUMMERS, Bruce J. Small-Value Transfer Systems. pp. 106-107.
} 


\subsection{O Processo de Compensação e Liquidação}

\subsubsection{Transmissão de Instrução de Pagamento}

A primeira etapa de todo processo de transferência de fundos é a transmissão de uma instrução de pagamento (a crédito ou a débito), sendo que a maioria dos sistemas de pagamentos somente aceitam instruções a crédito. $^{131}$

Em sistemas vinculados à transferência de títulos, a instrução de pagamento se confunde com a ordem de compra ou de venda lançada no mercado, visto que esta já envolve a transferência de recursos financeiros em contrapartida à transferência dos títulos.

\subsubsection{Compensação (Clearance ou Clearing)}

A compensação é o cálculo das obrigações de cada uma das partes em uma operação, podendo ser realizado pelo valor bruto ou líquido. ${ }^{132} \mathrm{Em}$ linhas gerais, ocorre a compensação pelo valor bruto, quando as obrigações são registradas, em sequência, por seu valor individual. Já a compensação pelo valor líquido pressupõe a extinção recíproca de obrigações, até onde elas se compensem, apurando-se um saldo final (ou líquido). Caso tal valor líquido seja obtido a partir das obrigações de dois agentes, estamos diante da denominada compensação pelo valor líquido bilateral. Se, por outro lado, envolver mais de dois agentes em conjunto, entende-se que ocorreu a compensação pelo valor líquido multilateral.

\footnotetext{
${ }^{131}$ SOUZA, Leandro Alves de. Sistema de pagamentos brasileiro: nova estrutura e seus impactos econômicos. São Paulo: Saraiva, 2001. p. 19.

${ }^{132}$ Cf. SETTLEMENTS, Bank for International. Delivery versus Payment in Securities Settlement Systems (September 1992, p. 10). Disponível em <http://www.bis.org/publ/cpss06.htm>. Acesso em 22 set. 2012. Entretanto, o referido estudo ainda destaca que o termo "clearance" também é, por vezes, utilizado como sinônimo de entrega, isto é, a transferência final de títulos na data de liquidação (Ibid., p. 11).
} 
Note-se que a compensação, em sentido amplo, não se confunde com a compensação prevista no art. 368 do Código Civil, o qual dispõe que:

"Art. 368. Se duas pessoas forem ao mesmo tempo credor e devedor uma da outra, as duas obrigações extinguem-se, até onde se compensarem."

Em vista do dispositivo acima, pode-se concluir que a compensação em sentido jurídico reflete apenas a modalidade de compensação pelo valor líquido. A noção ampla de compensação (em inglês, clearance ou clearing) é normalmente utilizada com o sentido de processamento, podendo incluir a transmissão, identificação, reconciliação e confirmação de instruções de pagamentos. $^{133}$

\subsubsection{Compensação pelo Valor Bruto}

A compensação pelo valor bruto se opera por meio do registro (i) da obrigação de entrega de recursos por um agente, e (ii) do direito ao recebimento desses recursos por outro, em decorrência de cada instrução de pagamento (ou negócio) considerada individualmente. Assim, diz-se que a compensação ocorre operação por operação. ${ }^{134}$

\subsubsection{Compensação pelo Valor Líquido (Netting)}

Já a compensação pelo valor líquido se opera por meio do cálculo (i) das obrigações totais suportadas por um agente, e (ii) dos direitos totais detidos por este mesmo agente. Assim, o montante financeiro a receber é subtraído pelo montante financeiro a pagar, resultando em um saldo líquido.

\footnotetext{
${ }^{133}$ Cf. SETTLEMENTS, Bank for International. Real-Time Gross Settlement Systems (March 1997, p. 3). Disponível em 〈http://www.bis.org/publ/cpss22.htm>. Acesso em 22 set. 2012.

${ }^{134}$ Cf. SOUZA, Leandro Alves de. Sistema de pagamentos brasileiro: nova estrutura e seus impactos econômicos. p. 20; e SETTLEMENTS, Bank for International; COMMISSIONS, International Organization of Securities. Principles for financial markets infrastructures (April 2012, p. 155). Disponível em < http://www.bis.org/publ/cpss101.htm>. Acesso em 22 set. 2012.
} 
A lógica econômica subjacente aos sistemas de compensação por valor líquido é descrita com precisão por Horii e Summers nos seguintes termos:

"Netting systems act to reduce, perhaps significantly, the intraday liquidity needed to settle large payments. In a netting system, these liquidity needs are met by de facto extension of credit among participants in the system. However, this credit is extended by the originators and receivers of payments over the system, not by the operator of the system." (grifos nossos) ${ }^{135}$

Como mencionado anteriormente, esse mecanismo é expressamente previsto nos artigos 368 e seguintes do Código Civil sob a figura da compensação. É importante destacar ainda que, embora esse instituto reflita diretamente a compensação bilateral, também serve de fundamento para a compensação multilateral, na medida em que esta decorre do resultado agregado da compensação bilateral dos participantes em um mesmo sistema.

\subsubsection{Compensação pelo Valor Líquido Bilateral}

A compensação pelo valor líquido pode ser realizada bilateralmente quando dois agentes concordam em extinguir as obrigações devidas reciprocamente, até o montante em que se equivalem. No Direito Brasileiro, essa modalidade de compensação ocorre automaticamente entre dívidas líquidas, vencidas e de coisas fungíveis, salvo acordo em contrário ou renúncia prévia por uma das partes, nos termos dos artigos 368, 369 e 375 do Código Civil.

\footnotetext{
${ }^{135}$ HORII, Akinari; SUMMERS, Bruce J. Large-Value Transfer Systems. In: SUMMERS, Bruce J. (editor). The Payment System: Design, Management, and Supervision. International Monetary Fund: Washington, D.C., 1994, p. 76.
} 


\subsubsection{Compensação pelo Valor Líquido Multilateral}

Por outro lado, a compensação pelo valor líquido será realizada de maneira multilateral quando forem apuradas em conjunto e consequentemente extintas, até onde se equivalem, as obrigações de três ou mais agentes envolvidos em um sistema de compensação. O mecanismo é descrito com precisão pela Lei $n^{\circ} 10.214 / 01$, ao prever que:

“Art. $3^{\circ}$ É admitida a compensação multilateral de obrigações no âmbito de uma mesma câmara ou prestador de serviços de compensação e de liquidação.

Parágrafo único. Para os efeitos desta Lei, define-se compensacão multilateral de obrigações o procedimento destinado à apuracão da soma dos resultados bilaterais devedores e credores de cada participante em relacão aos demais.." (grifos nossos)

A compensação multilateral pode ser realizada de maneira (i) descentralizada, quando uma entidade calcula as posições líquidas de todo o sistema e cada participante paga ou recebe recursos financeiros a partir de uma conta central de liquidação, ou (ii) centralizada, quando uma entidade atua como contraparte central, assumindo a responsabilidade por todos os pagamentos e recebimentos decorrentes da compensação multilateral. $^{136}$

A experiência com sistemas de compensação multilateral já demonstrou a possibilidade de redução do valor total de liquidação em até $90 \%$ em comparação com os sistemas de compensação pelo valor bruto. ${ }^{137}$

\subsection{Acordos de Compensação na Falência}

Os agentes econômicos podem ser contrapartes comuns em uma série de operações, o que ocorre frequentemente na relação entre bancos e seus clientes. A insolvência de um das partes implica na adoção de um

\footnotetext{
${ }^{136}$ Cf. BERGH, Paul Van den; VEALE, John M. Payment System Risk and Risk Management. In: SUMMERS, Bruce J. (editor). The Payment System: Design, Management, and Supervision. p. 95.

${ }^{137}$ BERGH, Paul Van den. Operational and Financial Structure of the Payment System. p. 39.
} 
procedimento específico para a cobrança das dívidas, enquanto os créditos podem ser cobrados normalmente. Essa grave distorção gerada pela insolvência é melhor demonstrada no exemplo a seguir.

Suponhamos que um agente A celebrou dois contratos bilaterais com um agente B. Após as contratações, o agente A enfrentou sérias dificuldades financeiras, resultando em sua insolvência. No momento em que se configurou a insolvência, o primeiro contrato gerava um crédito de $\mathrm{R} \$ 100.000,00$ a favor do agente A e o segundo contrato gerava uma dívida de $\mathrm{R} \$ 200.000,00$ contra o agente A. Uma diretriz comum nas legislações falimentares é que os contratos bilaterais não se resolvem com a insolvência, podendo o agente insolvente executá-los conforme o melhor interesse da massa. Assim, o agente B poderá ser obrigado a desembolsar $\mathrm{R} \$ 100.000,00$ para pagar o primeiro contrato (resolvido a critério do agente A), enquanto seu crédito de $\mathrm{R} \$ 200.000,00$ estará sujeito às incertezas do regime de insolvência. Essa distorção é conhecida internacionalmente como cherry picking e uma série de medidas vem sendo implementadas para mitigar seus efeitos.

Uma das principais medidas é a autorização para que o agente solvente possa compensar seus créditos perante o agente que se encontra regime de insolvência, pratica conhecida como netting. Embora a legislação civil brasileira estabeleça a compensação automática de obrigações, esta apenas se opera entre dívidas vencidas, o que não inibe totalmente os efeitos adversos do cherry picking. Assim, surgiram os denominados acordos de compensação (netting agreements) em que os agentes estabeleciam o vencimento antecipado e a imediata compensação de suas obrigações comuns no caso de insolvência.

A Lei 11.101/05, que trata da insolvência empresarial, embora tenha mantido a regra sobre contratos bilaterais existente no diploma anterior, tratou diretamente da compensação em seu art. 122:

"Art. 117. Os contratos bilaterais não se resolvem pela falência e podem ser cumpridos pelo administrador judicial se o cumprimento reduzir ou evitar o 
aumento do passivo da massa falida ou for necessário à manutenção e preservação de seus ativos, mediante autorização do Comitê. (...)" (grifos nossos)

"Art. 122. Compensam-se, com preferência sobre todos os demais credores, as dividas do devedor vencidas até o dia da decretacão da falência, provenha o vencimento da sentença de falência ou não, obedecidos os requisitos da legislação civil. (...)" (grifos nossos)

Além disso, o referido diploma legal tratou expressamente da compensação de obrigações no âmbito do Sistema Financeiro Nacional em seu art. 119, inciso VIII, nos seguintes termos:

\footnotetext{
"Art. 119. Nas relações contratuais a seguir mencionadas prevalecerão as seguintes regras: (...)

VIII - caso haja acordo para compensação e liquidação de obrigações no âmbito do sistema financeiro nacional, nos termos da legislação vigente, $\underline{a}$ parte nãa falida poderá considerar o contrato vencido antecipadamente, hipótese em que será liquidado na forma estabelecida em regulamento, admitindo-se $\boldsymbol{a}$ compensacão de eventual crédito que venha a ser apurado em favor do falido com créditos detidos pelo contratante; (...)" (grifos nossos)
}

Diante de tais mudanças na legislação falimentar, manifestou-se Otavio Yazbek:

“(...) apesar de manter a faculdade de cherry picking do síndico, o novo diploma estabelece, em seu artigo 119, regras excepcionais para algumas situações. (...) restou claro também que não se está, com tal mecanismo, afastando a ordem dos créditos perante a massa, mas sim tratando de um regime próprio para o cumprimento de determinadas obrigações. Deste regime surgirá um crédito passível de habilitação, nos termos e condições da Lei, ou, conforme o caso, que se deva pagar, também de acordo com o ali disposto." (grifos originais) ${ }^{138}$

$\mathrm{Na}$ linha das novas disposições trazidas pela Lei $\mathrm{n}^{\circ} 11.101 / 05$, o Conselho Monetário Nacional revisou suas regras sobre acordos de compensação, antes previstas na Resolução CMN n 3.039/02, editando uma nova regulamentação sobre o assunto, a Resolução CMN n ${ }^{\circ}$ 3.263/05.

De acordo com essa resolução, os acordos de compensação poderão ser firmados entre instituições financeiras e outras instituições autorizadas a

\footnotetext{
${ }^{138}$ YAZBEK, Otavio. O risco de crédito e os novos instrumentos financeiros - uma análise funcional.p. 334.
} 
funcionar pelo Banco Central do Brasil e pessoas físicas ou jurídicas, sejam integrantes ou não do Sistema Financeiro Nacional (arts. $1^{\circ}$ e $2^{\circ}$ ).

Como se trata de pactos que excluem determinadas relações do regime falimentar normalmente aplicável, o regulador se preocupou com a publicidade dada a tais acordos.

Assim, os acordos de compensação poderão ser constituídos por meio de contrato específico por instrumento público ou particular. No último caso, a eficácia desses acordos dependerá de registro em títulos e documentos ou em sistema de registro e de liquidação financeira de ativos autorizado a funcionar pelo Banco Central do Brasil ou, ainda, em entidade credenciada para o registro de operações de mercados organizados de derivativos (art. $3^{\circ}$, caput e $\$ 1^{\circ}$ )

Por outro lado, dispensa-se um contrato específico em operações de derivativos que contem com acordos globais de compensação e liquidação, desde que tal acordo esteja sujeito a registro em entidade que opere os mercados organizados de derivativos (art. $3^{\circ}, \S 2^{\circ}$ ). Assim, as partes podem contar com o mecanismo de compensação por meio de uma cláusula específica em um contrato global, normalmente denominada cláusula de vencimento antecipado e imediata compensação (close-out netting clause).

As adaptações promovidas pela nova legislação falimentar e pela Resolução CMN no 3.263/05 merecem aplausos, uma vez que garantem maior segurança aos acordos de compensação, alinhando a regulamentação da matéria às melhores práticas internacionais. ${ }^{139}$

\footnotetext{
${ }^{139}$ Como já destacado pelo Group of Thirty, em estudo dedicado ao aprimoramento dos regimes de insolvência: "Recommendation 9: In jurisdictions where there is still doubt about the enforceability of close-out netting, legislators should clarify the position as quickly as possible." (grifos originais). (THIRTY, Group of. International Insolvencies in the Financial Sector: A Study Group Report. Group of Thirty: Washington, D.C., 1998, p. 45).
} 


\subsubsection{Liquidação (Settlement)}

A liquidação é o processo de extinção das obrigações calculadas na etapa de compensação por meio de seu cumprimento. Em uma operação envolvendo a transferência de títulos, a liquidação representa a conclusão da operação por meio da entrega do título do vendedor ao comprador (delivery) e a respectiva transferência de recursos financeiros do comprador ao vendedor (payment). ${ }^{140}$

\subsubsection{Liquidação em Tempo Real e Diferida}

A liquidação em tempo real (ou contínua) é aquela em que o processamento das instruções ocorre individualmente no momento em que são recebidas. Os sistemas de liquidação em tempo real realizam a compensação pelo valor bruto, visto que, por definição, a compensação pelo valor líquido envolve a acumulação de uma série de operações para que os créditos possam ser compensados pelos débitos. ${ }^{141}$

Já a liquidação diferida (ou em momento designado) ocorre em momento futuro ao recebimento das instruções em um ou mais intervalos predefinidos, os denominados ciclos de compensação (clearing cycles). Os sistemas de liquidação diferida podem realizar a compensação pelo valor líquido ou operação por operação.

\footnotetext{
${ }^{140}$ Cf. Art. $3^{\circ}$, item XXXIV, do Regulamento da CETIP. Disponível em <http://www.cetip.com.br/ informacao tecnica/regulamento e manuais/regulamento/Regulamento_CETIP.pdf $>$. Acesso em 07 out. 2012; e SETTLEMENTS, Bank for International. Delivery versus Payment in Securities Settlement Systems (September 1992, pp. 10, A2-6). Disponível em <http://www.bis. org/publ/cpss06.htm>. Acesso em 22 set. 2012.

${ }^{141}$ THIRTY, Group of. Global Clearing and Settlement: A Plan of Action. Group of Thirty: Washington, D.C., 2003, p. 134. Disponível em <http://www.group30.org/rpt 12.shtml〉. Acesso em 22 set. 2012; e SETTLEMENTS, Bank for International. Real-Time Gross Settlement Systems (March 1997, p. 5). Disponível em <http://www.bis.org/publ/cpss22.htm>. Acesso em 22 set. 2012.
} 


\subsubsection{Liquidação Provisória e Final}

A liquidação de uma obrigação pode ocorrer de modo provisório quando é passível de revogação ou condicionada a determinado evento. Por um lado, o estorno dos recursos financeiros transferidos é um mecanismo de segurança ao emissor da instrução de pagamento, porém o beneficiário enfrenta grande incerteza durante certo período.

$\mathrm{O}$ risco de crédito suportado pelo beneficiário de uma ordem provisória o impede de dispor efetivamente do montante financeiro que recebeu. Como não tem segurança de que tal quantia integrará seu patrimônio no futuro, não irá pagar suas contas, distribuir dividendos ou investir em novos projetos. ${ }^{142}$

Em vista dos riscos gerados pela liquidação provisória, consolidou-se internacionalmente a noção de liquidação final (settlement finality). De acordo com a orientação do Bank for International Settlements e da International Organization of Securities Commissions:

\section{"Principle 8: Settlement finality}

An FMI [Financial Market Infrastructure] should provide clear and certain final settlement, at a minimum by the end of the value date. Where necessary or preferable, na FMI should provide final settlement intraday or in real time.

\section{(...)}

Final settlement is defined as the irrevocable and unconditional transfer of an asset or financial instrument, or the discharge of an obligation by the FMI or its participants in accordance with the terms of the underlying contract." ${ }^{143}$ (grifos originais)

Já no âmbito dos sistemas de transferência de títulos, a exigência de liquidação final se traduziu no princípio de entrega contra pagamento

\footnotetext{
${ }^{142}$ Cf. BERGH, Paul Van den; VEALE, John M. Payment System Risk and Risk Management. p. 92; e BHALA, Raj. Legal Foundations of Large-Value Transfer Systems. In: SUMMERS, Bruce J. (editor). The Payment System: Design, Management, and Supervision. p. 65.

${ }^{143}$ SETTLEMENTS, Bank for International; COMMISSIONS, International Organization of Securities. Principles for financial markets infrastructures (April 2012, p. 64). Disponível em <http://www.bis.org/publ/cpss101.htm〉. Acesso em 22 set. 2012.
} 
(delivery versus payment), em que a entrega dos títulos ocorre se, e somente se, a transferência dos recursos financeiros ocorrer.

\subsection{Desenhos Institucionais Típicos (RGTS e DNS)}

A combinação das estruturas e regras acima resultou em dois desenhos institucionais típicos.

O sistema de liquidação pelo valor bruto em tempo real (real-time gross settlement system - RGTS) representa um eficiente mecanismo de redução dos riscos existentes nos processos de pagamento, na medida em que a liquidação em tempo real elimina potencialmente a exposição dos agentes econômicos aos riscos de crédito e liquidez, além de contribuir para o controle do risco sistêmico. Entretanto, não se pode afirmar que o risco sistêmico seja totalmente neutralizado, pois a incapacidade de um agente efetuar seus pagamentos ainda pode repercutir diretamente na capacidade dos demais agentes cumprirem suas respectivas obrigações, podendo levar a situações de gridlock com potenciais consequências sistêmicas. ${ }^{144}$

Uma fraqueza desse modelo é a necessidade de que seus participantes mantenham ao longo do dia recursos prontamente disponíveis em volume suficiente para saldar seus débitos. A necessidade de recursos à disposição acarreta um custo de oportunidade e demanda estratégias de gerenciamento de liquidez dos participantes, como a concessão de crédito pelo Banco Central ou a obtenção de empréstimos privados com outros participantes. $^{145}$

\footnotetext{
${ }^{144}$ Cf. SOUZA, Leandro Alves de. Sistema de pagamentos brasileiro: nova estrutura e seus impactos econômicos. pp. 24-25; e BERGH, Paul Van den; VEALE, John M. Payment System Risk and Risk Management. p. 103. As situacões de gridlock são definidas como situações de iliquidez em um sistema de pagamentos, o que pode ocorrer quando a liquidez agregada do sistema não é suficiente ou, ainda que suficiente, sua má distribuição impede o fluxo normal de pagamentos (Cf. FOLKERTS-LANDAU, David. Wholesale payments and financial discipline, efficiency, and liquidity. Working paper 154. Washington, D.C.: IMF, 1997. apud. SOUZA, Leandro Alves de. Op. cit., p. 27).
}

${ }^{145}$ SOUZA, Leandro Alves de. Op. cit., p. 25. 
Já o sistema de liquidação diferida líquida (deferred net settlement system - DNS), normalmente associado às denominadas Clearing Houses, reduz a necessidade de liquidez de seus participantes, resultando em maior eficiência. Por outro lado, o intervalo existente entre o início das negociações e sua liquidação final é sua principal fonte de risco de crédito e liquidez, resultando em acúmulo de pressão no final de tal período. Além disso, nesse sistema se identifica mais claramente a dispersão do risco de cada participante, o que reduz a pressão individual, embora acarrete maior compartilhamento de riscos. ${ }^{146}$

A mutualização de riscos nesse sistema é uma importante fonte de risco sistêmico, razão pela qual são vinculados a sistemas de transferência de recursos em contas do Banco Central e merecem especial atenção desse regulador. A supervisão de seus mecanismos de controle de risco é rigorosa e obedece a padrões internacionais mínimos, originalmente conhecidos como Lamfalussy Standards. ${ }^{147}$

Em síntese, identifica-se um trade-off entre eficiência e risco no planejamento de modelos de transferência de grande valor e nenhum

${ }^{146}$ Cf. BERGH, Paul Van den; VEALE, John M. Payment System Risk and Risk Management. p. 95.

${ }^{147}$ Os Lamfalussy Standards, divulgados internacionalmente em 1990, representaram um importante desenvolvimento na matéria e serviram de base para outros estudos e recomendações internacionais (como o Core principles for systemically important payment systems, publicado em 2001, e, mais atualmente, o Principles for financial markets infrastructures, publicado em 2012). Por sua relevância no balizamento inicial da regulação, apresentamos essas recomendações a seguir: "I. Netting schemes should have a well-founded legal basis under all relevant jurisdictions. II. Netting scheme participants should have a clear understanding of the impact of the particular scheme on each of the financial risks affected by the netting process. III. Multilateral netting systems should have clearly-defined procedures for the management of credit risks and liquidity risks which specify the respective responsibilities of the netting provider and the participants. These procedures should also ensure that all parties have both the incentives and the capabilities to manage and contain each of the risks they bear and that limits are placed on the maximum level of credit exposure that can be produced by each participant. IV. Multilateral netting systems should, at a minimum, be capable of ensuring the timely completion of daily settlements in the event of an inability to settle by the participant with the largest single net-debit position. V. Multilateral netting systems should have objective and publicly-disclosed criteria for admission, which permit fair and open access. VI. All netting schemes should ensure the operational reliability of technical systems and the availability of back-up facilities capable of completing daily processing requirements." (SETTLEMENTS, Bank for International. Report of the Committee on Interbank Netting Schemes of the Central Banks of the Group of Ten Countries (November 1990, pp. 3-4). Disponível em <http://www.bis.org/publ/cpss04.pdf>. Acesso em 20 out. 2012) 
modelo individual é necessariamente o mais adequado a cada situação, embora a combinação entre estruturas públicas e privadas seja possivelmente uma solução ótima para a questão. ${ }^{148}$

\section{TERCEIRA PARTE - CONTRAPARTES CENTRAIS NOS MERCADOS DE DERIVATIVOS}

\section{Capítulo V - Sistema de Pagamentos Brasileiro}

Nos últimos anos, o desenvolvimento dos mercados e a expansão de negociações envolvendo diferentes segmentos e moedas foram os principais propulsores do debate internacional sobre o aprimoramento dos sistemas de pagamentos, notadamente após a crise do mercado de capitais internacional de 1987. Desde então, uma série de estudos foi conduzida, prioritariamente pelo Bank for International Settlements, resultando em um arcabouço de recomendações e práticas internacionalmente aceitas. A linha central dessas orientações era a redução do risco sistêmico, ou seja, a possibilidade de disseminação de problemas de crédito e liquidez por meio dos sistemas de pagamentos. $^{149}$

Na segunda metade dos anos 90, a estabilização e inserção do Brasil no processo de globalização resultaram em uma transformação substancial do sistema financeiro, acarretando discussões sobre os riscos existentes no setor. Nesse momento, a liquidação final de recursos financeiros ocorria em geral uma vez ao dia pelo valor líquido nas reservas bancárias, o que gerava déficits ao longo do dia da ordem de R\$6 bilhões. A imensa exposição do

\footnotetext{
${ }^{148}$ Cf. HORII, Akinari; SUMMERS, Bruce J. Large-Value Transfer Systems. pp. 87-88.

149 Cf. ANDIMA, Associação Nacional das Instituições do Mercado Aberto. Sistema de Pagamentos Brasileiro (Relatório Econômico). Rio de Janeiro: ANDIMA, 2002, pp. 7-8.
} 
Banco Central ameaçava o sistema financeiro e a economia como um todo. ${ }^{150}$

Assim, o Banco Central liderou o projeto de reestruturação do sistema de pagamentos brasileiro, visando alinhar o país às orientações internacionais existentes. Dentre as modificações estabelecidas no projeto, duas merecem especial destaque: (i) o fato de que o Banco Central não mais aceitaria saldo negativo nas reservas bancárias em nenhum momento ao longo do dia, o que resultou na criação de um sistema de liquidação bruta em tempo real para sensibilização de sua contas, o denominado Sistema de Transferência de Reservas - STR; e (ii) na área privada, a criação e adaptação de sistemas de compensação ou liquidação, com vistas a assegurar a contenção de riscos nesses ambientes, por meio de mecanismos e procedimentos de garantia. ${ }^{151}$

Assim, em 14 de dezembro de 1999, a Medida Provisória no 2.008 estabeleceu as normas legais necessárias à implantação do novo sistema de pagamentos brasileiro. A medida provisória foi posteriormente convertida na Lei $\mathrm{n}^{\circ} 10.214 / 01$ e uma série de normativos foi editada para detalhar o funcionamento dos novos mecanismos.

A Resolução CMN $\mathrm{n}^{\circ}$ 2.882/01 estabeleceu os princípios da eficiência, segurança, integridade e confiabilidade como norteadores do sistema de pagamentos (art. $1^{\circ}$ ), além de traçar as linhas gerais para o funcionamento das entidades privadas de compensação e liquidação, em complemento às disposições da Lei ${ }^{\circ}$ 10.214/01. As diretrizes recepcionam as principais orientações internacionais para os sistemas de pagamento, em especial, as exigências de liquidação final, entrega contra pagamento, transparência e gerenciamento de riscos de crédito e liquidez (art. $3^{\circ}$ ). Além disso, também é atribuída competência para o BACEN e a CVM regulamentarem suas disposições, conforme o caso (art. 11).

\footnotetext{
${ }^{150}$ Cf. ANDIMA, Associação Nacional das Instituições do Mercado Aberto. Sistema de Pagamentos Brasileiro (Relatório Econômico). pp. 7-13.

${ }^{151}$ Cf. Ibid., pp. 13-14.
} 
A Circular BACEN n 3.057/01, então, aprovou o regulamento que disciplina o funcionamento dos sistemas operados pelas câmaras e pelos prestadores de serviços de compensação e de liquidação. Um dos pontos fundamentais desse normativo é a definição de "sistema sistemicamente importante". A noção foi explorada, sobretudo no estudo Core Principles for Sistematically Important Payment Systems, elaborado pelo Bank for International Settlements em 2001, e se tornou um conceito-chave na regulação dos sistemas de pagamento, em vista de seu papel central no gerenciamento do risco sistêmico. Nos termos do art. $2^{\circ}$, XXIII, da Circular:

"sistema sistemicamente importante: sistema de liquidação em que o volume ou a natureza dos negócios, a critério do Banco Central do Brasil, é capaz de oferecer risco à solidez e ao normal funcionamento do Sistema Financeiro Nacional."

Já a Circular BACEN $n^{\circ}$ 3.100/02 instituiu o Sistema de Transferência de Reservas - STR como sistema de liquidação bruta em tempo real, administrado pelo Banco Central, para transferência de recursos detidos nas reservas bancárias.

No que tange aos sistemas destinados à transferência de valores mobiliários, a CVM editou a Instrução $n^{\circ}$ 461/07, disciplinando o funcionamento das bolsas de valores e de mercadorias, assim como das entidades administradoras de mercados de balcão.

Nessa linha, o novo sistema de pagamentos brasileiro adotou um modelo híbrido, que envolve a compensação e liquidação de obrigações por entes privados, em combinação com a liquidação final em um sistema público de transferência de recursos, alinhando-se às principais diretrizes internacionais. $^{152}$

\footnotetext{
${ }^{152} \mathrm{O}$ equilíbrio promovido por esse modelo é descrito com precisão por Valdir Carlos Pereira Filho, nos seguintes termos: "Uma vez que o Banco Central só admite lançamentos com provisão de fundos, se a ordem de um participante ocasionar saldo em reserva negativo, o Banco Central a rejeitará. Entretanto, esta rejeição de ordem não ocasionará prejuízo aos demais participantes ou contrapartes do inadimplente, porque a clearing honrará e garantirá o pagamento das obrigações assumidas em seu ambiente. A clearing como contraparte central garantidora, administradora de riscos e de garantias dá segurança ao Banco Central para rejeitar ordens que geram saldo devedor porque elas absorverão os riscos dos participantes." (grifos nossos) (FILHO, Valdir Carlos Pereira. Clearing Houses: Aspectos Jurídicos Relevantes e seu Papel no Mercado de
} 


\section{Capítulo VI - Clearing de Derivativos}

Traçado o panorama geral dos sistemas de pagamentos, incluindo o brasileiro em seu desenho atual, podemos analisar mais detidamente o funcionamento das contrapartes centrais em sistema de compensação e liquidação de derivativos.

Como analisado na Primeira Parte deste estudo, os derivativos são instrumentos financeiros de alta volatilidade, podendo gerar ganhos e perdas consideráveis em um curto espaço de tempo, além de bruscas variações nas exposições dos agentes devido à velocidade envolvida em sua negociação. Nesse cenário, o controle adequado de riscos e liquidez é fundamental.

Alguns dos derivativos mais tradicionais migraram para sistemas centralizados de negociação e liquidação, onde sua eficiência poderia ser potencializada e seus riscos melhor gerenciados. As instituições que administravam esses sistemas ficaram conhecidas como Clearing Houses e o processamento das operações passou a ser denominado genericamente como a atividade de Clearing.

A segurança e a eficiência demandadas por essas operações deram origem a diversos mecanismos de controle de risco e administração de liquidez, razão pela qual as Clearing Houses nos mercados de derivativos aproximaram-se do modelo de liquidação diferida pelo valor líquido multilateral.

Capitais e no Sistema de Pagamentos Brasileiro. Revista de Direito Bancário e do Mercado de Capitais. São Paulo: Revista dos Tribunais, 2005, vol. 27, p. 64) 


\section{Capítulo VII - Contrapartes Centrais}

\section{Conceito e Importância Econômica}

A compensação de obrigações pelo saldo líquido multilateral envolve diferentes agentes de um sistema, sendo necessária a existência de uma entidade comum a todos. Na linha de desenvolvimento desses sistemas e do próprio mercado de derivativos, uma necessidade de maior segurança deu origem à prática internacional em que certa instituição não apenas calculava o valor líquido multilateral, mas também garantia a liquidação de todas as operações.

Essa instituição, denominada de contraparte central, pode ser definida como um agente que se interpõe entre as partes originais de cada operação, assumindo a posição de compradora de todos os vendedores e vendedora de todos os compradores, o que implica em sua responsabilidade pela liquidação das operações registradas. ${ }^{153} \mathrm{O}$ assunto é tratado diretamente pela Lei ${ }^{\circ} 10.214 / 01$, nos seguintes termos:

\footnotetext{
"Art. 4 ${ }^{\circ}$ Nos sistemas em que o volume e a natureza dos negócios, a critério do Banco Central do Brasil, forem capazes de oferecer risco à solidez e ao normal funcionamento do sistema financeiro, as câmaras e os prestadores de servicos de compensação e de liquidação assumirão, sem prejuízo de obrigações decorrentes de lei, regulamento ou contrato, em relação a cada participante, a posição de parte contratante, para fins de liquidação das obrigacões, realizada por intermédio da câmara ou prestador de serviços.

$\S 1^{\circ}$ As câmaras e os prestadores de serviços de compensação e de liquidação não respondem pelo adimplemento das obrigações originárias do emissor, de resgatar o principal e os acessórios de seus títulos e valores mobiliários objeto de compensação e de liquidação. (...)" (grifos nossos)
}

\footnotetext{
${ }^{153}$ Segundo o professor Nelson Eizirik, a responsabilidade de liquidar as operações se traduz em uma obrigacão de garantia, na medida em que consiste na eliminação de um risco suportado pelo credor. Em sentido contrário, Eduardo Salomão Neto argumenta, ao analisar o papel desempenhado pela BM\&F nas operações de derivativos, que o termo "garantia" apenas reflete a forma como a participação dessa entidade é chamada no mercado financeiro, pois "na realidade a $\mathrm{BM} \& \mathrm{~F}$ não dá garantia, mas assume posição de contraparte nas operações" (grifos nossos) (Cf. EIZIRIK, Nelson. Aspectos jurídicos dos mercados futuros. p. 31; e NETO, Eduardo Salomão. Direito Bancário. p. 341).
} 
De acordo com a linha de raciocínio mais tradicional, tal posição é obtida a partir do instituto da novação, em que as obrigações originais entre as partes são extintas e substituídas por novas obrigações de cada agente perante a contraparte central. Concordam com essa visão, Luiz Gastão Paes de Barros Leães, Valdir Carlos Pereira Filho e indiretamente Marcos Paulo de Almeida Salles. Já em sentido contrário, Francisco Satiro de Souza Júnior afirma que não haveria novação, em vista do caráter definitivo da interposição da contraparte central entre os agentes. ${ }^{154}$

A arquitetura apresentada acima apresenta uma série de benefícios econômicos, dentre os quais destacamos: (i) a liquidação diferida a partir do valor líquido multilateral diminui a pressão sobre os agentes econômicos; (ii) os diferentes níveis de riscos de crédito e liquidez de cada agente são substituídos pelos riscos de um único agente, a contraparte central, cuja solidez financeira é garantida por um conjunto de agentes, além de ser rigorosamente controlada; (iii) como analisaremos abaixo, as liquidações diárias promovidas pela contraparte central e a padronização das operações garantem liquidez aos agentes, na medida em que facilitam a troca e extinção de posições compradas ou vendidas, por meio da realização de operações em sentido contrário; (iv) os sofisticados mecanismos de gestão de risco detidos pelas contrapartes centrais reduzem o risco sistêmico; e (v) a liquidação centralizada garante maior transparência às operações e exposições de cada agente.

Por outro lado, as contrapartes centrais concentram os riscos de todos os agentes de um mercado, razão pela qual devem adotar um conjunto de procedimentos e mecanismos de proteção. Dada a relevância dessas estruturas para a solidez das contrapartes centrais e, em última instância, do

\footnotetext{
${ }^{154}$ Cf. DIAS, Gustavo Neto de Carvalho. As caixas de liquidação no âmbito do sistema de pagamentos brasileiro. São Paulo: Faculdade de Direito, Universidade de São Paulo, 2011, p. 48. (Dissertação de Mestrado) Disponível em <http://www.teses.usp.br/teses/disponiveis/2/2132/tde26042012-140310/>. Acesso em 21 out. 2012; e FILHO, Valdir Carlos Pereira. Clearing Houses: Aspectos Jurídicos Relevantes e seu Papel no Mercado de Capitais e no Sistema de Pagamentos Brasileiro. p. 64.
} 
próprio sistema financeiro, a matéria tem o status de obrigação legal no Direito Brasileiro, conforme disposto na Lei $\mathrm{n}^{\circ} 10.214 / 01$ :

"Art. $4^{\circ}$ Nos sistemas em que o volume e a natureza dos negócios, a critério do Banco Central do Brasil, forem capazes de oferecer risco à solidez e ao normal funcionamento do sistema financeiro, as câmaras e os prestadores de serviços de compensação e de liquidação assumirão, sem prejuízo de obrigações decorrentes de lei, regulamento ou contrato, em relação a cada participante, a posição de parte contratante, para fins de liquidação das obrigações, realizada por intermédio da câmara ou prestador de serviços.

\section{(...)}

$\S 2^{\underline{0}}$ Os sistemas de que trata o caput deverão contar com mecanismos $\boldsymbol{e}$ salvaguardas que permitam às câmaras e aos prestadores de serviços de compensação e de liquidação assegurar a certeza da liquidação das operações neles compensadas e liquidadas.

$\S 3^{0}$ Os mecanismos e as salvaguardas de que trata o parágrafo anterior compreendem, dentre outros, dispositivos de seguranca adequados e regras de controle de riscos, de contingências, de compartilhamento de perdas entre os participantes e de execução direta de posições em custódia, de contratos e de garantias aportadas pelos participantes." (grifos nossos)

Além disso, a Lei $n^{\circ} 12.543 / 11$, complementou o art. $3^{\circ}$ da Lei $n^{\circ}$ 6.385/76, estabelecendo que o CMN deverá:

"VI - estabelecer, para fins da política monetária e cambial, condições específicas para negociação de contratos derivativos, independentemente da natureza do investidor, podendo, inclusive:

a) determinar depósitos sobre os valores nocionais dos contratos; e

b) fixar limites, prazos e outras condições sobre as negociações dos contratos derivativos."

Por sua vez, o desenvolvimento tecnológico e a sofisticação dos instrumentos financeiros também contribuíram para a implementação de diversos mecanismos de salvaguarda, sendo os mais relevantes analisados abaixo. 


\section{Regras de Acesso e Cadeia de Responsabilidades}

Uma contraparte central pode se relacionar com agentes econômicos de forma direta ou indireta. Na participação direta, a contraparte central estabelece requisitos mínimos de ordem operacional, legal e financeira para o acesso ao sistema de compensação e liquidação garantida, devendo inclusive monitorar regularmente a manutenção de tais parâmetros mínimos. O equilíbrio entre liberdade de acesso e riscos deve ser perseguido por mecanismos de controle e compartilhamento de riscos que resultem no menor impacto possível sobre o acesso e a competitividade. ${ }^{155}$ Já na participação indireta, por meio de corretoras e/ou agentes de compensação, a contraparte central precisa identificar, monitorar regularmente e gerenciar os riscos e interdependências existentes na cadeia de participantes, sobretudo porque as situações de inadimplemento podem gerar riscos caso a responsabilidade de tais participantes não esteja bem definida. $^{156}$

No Brasil, as operações de derivativos negociadas na BM\&FBovespa se submetem à seguinte cadeia de responsabilidade para sua liquidação: (i) os comitentes são responsáveis perante as corretoras; (ii) as corretoras são responsáveis perante os membros de compensação; e (iii) os membros de compensação são responsáveis perante a câmara de derivativos, que atua na condição de contraparte central nos termos do art. $4^{\circ}$ da Lei 10.214/01. ${ }^{157}$

\footnotetext{
155 Nesse sentido, apresenta-se o Princípio 18 do estudo Principles for financial markets infrastructures, elaborado pelo Bank for Intenational Settlements, em conjunto com a International Organization of Securities Commissions (SETTLEMENTS, Bank for International; COMMISSIONS, International Organization of Securities. Principles for financial markets infrastructures (April 2012, pp. 101-104). Disponível em 〈http://www.bis.org/publ/cpss101.htm>. Acesso em 22 set. 2012).

${ }^{156}$ Conforme o Princípio 19 do estudo Principles for financial markets infrastructures, elaborado pelo Bank for Intenational Settlements, em conjunto com a International Organization of Securities Commissions (SETTLEMENTS, Bank for International; COMMISSIONS, International Organization of Securities. Principles for financial markets infrastructures (April 2012, pp. 105 108). Disponível em <http://www.bis.org/publ/cpss101.htm >. Acesso em 22 set. 2012).

${ }^{157}$ Vide o Item 1.2. do Capítulo IV do Manual de Procedimentos Operacionais da Câmara de Derivativos: Segmento BM\&F. Disponível em <http://www.bmfbovespa.com.br/pt-br/regulacao
} 


\section{Margens de Garantia}

\subsection{Conceito e Natureza Jurídica}

O principal mecanismo de proteção das contrapartes centrais é a exigência de margem dos participantes, a qual consiste no depósito de garantias com vistas a assegurar o cumprimento de suas obrigações em caso de inadimplemento.

De acordo com o professor Eduardo Salomão Neto, a margem deve ser compreendida como depósito irregular ou penhor, conforme a fungibilidade dos bens utilizados. Caso a garantia seja prestada na forma de dinheiro ou outro bem fungível (por exemplo, valores mobiliários) ficará caracterizado o depósito irregular nos termos do art. 645 do Código Civil. Assim, o bem depositado passará a ser de propriedade da contraparte central, remanescendo o depositante apenas com um crédito condicionado ao cumprimento de todas as obrigações contratadas na operação de derivativo. Por outro lado, caso o bem oferecido seja de natureza infungível, haverá um simples penhor em benefício da contraparte central. $^{158}$

O referido autor ainda prossegue no assunto, com base nas lições de Francesco Messineo, para afirmar a impossibilidade de equiparação da margem às arras ou ao pagamento parcial, nos seguintes termos:

\footnotetext{
"Encarar a margem como depósito irregular ou penhor, conforme a fungibilidade dos bens em que se traduz, nos parece qualificação melhor de sua natureza jurídica do que a proposta rival que a vê como arras. As arras devem ser restituídas em dobro se desfeito o negócio por fato de quem as recebeu, e são na falta de estipulação em contrário consideradas início de pagamento, segundo a regra dos artigos 417 e 418 do Código Civil de 2002. Quando a margem é depositada, o contrato com a $B M \& F$ [contraparte centrall já está firmado e é vinculante, sendo a margem já uma etapa de sua execução, e não pagamento
}

/regulamentos-e-normas/procedimentos-operacionais/derivativos.aspx?Idioma=pt-br $>$. Acesso em 21 out. 2012.

${ }^{158}$ Cf. NETO, Eduardo Salomão. Direito Bancário. p. 346. 
confirmatório da conclusão do contrato, como as arras. Por fim, também não representam pagamento parcial, uma vez que a obrigação de pagamento nem sequer ainda existe. Pode ocorrer, por exemplo, inversão de posição, caso em que os valores recebidos em margem deverão ser devolvidos a quem os prestou." (grifos nossos) ${ }^{159}$

No mesmo sentido, o professor Nelson Eizirik entende que a margem seria uma modalidade de caução necessária, visto que sua função é garantir a solvabilidade de uma das partes - gerando a liquidação compulsória da posição contratual caso não tenha sido prestada ou, por outro lado, assegurando a intangibilidade de tal posição quando prestada adequadamente. ${ }^{160}$

Assim, em caso de inadimplemento, a contraparte central poderá se valer dos ativos depositados (fungíveis ou infungíveis), alienando-os para saldar as obrigações inadimplidas, mesmo diante da insolvência do devedor. É o que dispõem os arts. $7^{\circ}$ e $8^{\circ}$ da Lei no $10.214 / 01$ :

"Art. $7^{\circ}$ Os regimes de insolvência civil, concordata, intervenção, falência ou liquidacão extrajudicial, a que seja submetido qualquer participante, não afetarão o adimplemento de suas obrigações, assumidas no âmbito das câmaras ou prestadores de serviços de compensação e de liquidação, que serão ultimadas e liquidadas pela câmara ou prestador de serviços, na forma de seus regulamentos.

Parágrafo único. $O$ produto da realização das garantias prestadas pelo participante submetido aos regimes de que trata o caput, assim como os títulos, valores mobiliários e quaisquer outros seus ativos, objeto de compensação ou liquidação, serão destinados à liquidacão das obrigacões assumidas no âmbito das câmaras ou prestadores de serviços.

Art. $8^{\circ}$ Nas hipóteses de que trata o artigo anterior, ou quando verificada a inadimplência de qualquer participante de um sistema, a liquidação das obrigacões, observado o disposto nos regulamentos e procedimentos das câmaras ou prestadores de serviços de compensação e de liquidação, dar-se-á:

I - com a tradição dos ativos negociados ou a transferência dos recursos, no caso de movimentação financeira; e

II - com a entrega do produto da realização das garantias e com a utilização dos mecanismos e salvaguardas de que tratam os $\S \S 2^{\mathrm{o}}$ e $3^{\mathrm{o}}$ do art. $4^{\circ}$, quando inexistentes ou insuficientes os ativos negociados ou os recursos a transferir.

Parágrafo único. Se, após adotadas as providências de que tratam os incisos I e II, houver saldo positivo, será ele transferido ao participante, integrando a respectiva massa, se for o

\footnotetext{
159 NETO, Eduardo Salomão. Direito Bancário. pp. 347-348.

${ }^{160}$ Cf. EIZIRIK, Nelson. Aspectos jurídicos dos mercados futuros. p. 34.
} 
caso, e se houver saldo negativo, constituirá ele crédito da câmara ou do prestador de serviços de compensação e de liquidação contra o participante." (grifos nossos)

Aliás, a própria Lei $\mathrm{n}^{\mathrm{o}}$ 11.101/05 corroborou expressamente essa sistemática, ao estabelecer que:

"Art. 193. O disposto nesta Lei não afeta as obrigacõos assumidas no âmbito das câmaras ou prestadoras de servicos de compensação e de liquidação financeira, que serão ultimadas e liquidadas pela câmara ou prestador de serviços, na forma de seus regulamentos.

Art. 194. O produto da realizacão das garantias prestadas pelo participante das câmaras ou prestadores de serviços de compensação e de liquidação financeira submetidos aos regimes de que trata esta Lei, assim como os títulos, valores mobiliários e quaisquer outros de seus ativos objetos de compensacão ou liquidacão serão destinados à liquidacão das obrigacões assumidas no âmbito das câmaras ou prestadoras de serviços." (grifos nossos)

Não é por outro motivo que a Câmara Reservada de Direito Empresarial do Tribunal de Justiça de São Paulo, em acórdão unânime proferido em 17 de abril de 2012, manteve decisão de primeiro grau que determinou exclusão de crédito oriundo de cessão cursada na CETIP nos autos da recuperação judicial das sociedades Agrisul Agrícola Ltda., Jotapar Participações Ltda. e Cia. Brasileira de Açúcar e Álcool - cuja ementa transcrevemos abaixo:

\footnotetext{
"Recuperação Judicial - Obrigação assumida via Câmara de Compensação e Liquidação Financeira - Exclusão do crédito a pedido do credor após habilitação - Admissibilidade - Arts. 19, 194 e 195 da Lei 11.101/2005 - Produto da realização das garantias prestadas pelo participante submetido ao regime da Lei 10.214/2001 a ser destinado à liquidação das obrigações assumidas no âmbito das câmaras - Exclusão do crédito determinada - Recurso improvido." (grifos nossos) ${ }^{161}$
}

Não resta dúvida, portanto, de que a disciplina acima se sobrepõe aos preceitos legais que vedam a alienação da coisa empenhada (art. 1.428 do Código Civil) ou estabelecem uma ordem específica para o pagamento de créditos em caso de insolvência (art. 186 do Código Tributário Nacional e art. 102 do Decreto-lei ${ }^{\circ} 7.661 / 45$, este atualmente refletido no art. 83 da

${ }^{161}$ TJSP, AgIn n ${ }^{\circ}$ 0304899-85.2011.8.26.0000, Rel. Elliot Akel, São Paulo, 17 de abril de 2012. 
Lei $\mathrm{n}^{\mathrm{o}}$ 11.101/05). ${ }^{162}$ Assim desejou o legislador nacional, pois, do contrário, os sistemas de compensação e liquidação simplesmente deixariam de cumprir uma de suas funções primordiais, promover a segurança e a certeza no cumprimento de obrigações financeiras.

\subsection{Espécies de Margens}

$\mathrm{Na}$ regulação internacional, as contrapartes centrais podem exigir três espécies de margens: initial margin, maintenance margin e variation margin. Como veremos a seguir, a initial margin e a manitenance margin representam típicas modalidades de margem de garantia no Direito Brasileiro. Entretanto, a variation margin, conhecida no Brasil como ajuste diário, é utilizada de maneira que dificulta seu enquadramento nessa mesma categoria.

A margem inicial (initial margin) é exigida no momento em que a operação é celebrada como forma de proteção diante da exposição futura dos contratantes. De acordo com a prática internacional, as margens iniciais devem satisfazer um nível de confiança de, no mínimo, 99\% da distribuição estimada de exposição futura. Seu cálculo resulta da avaliação dos possíveis efeitos da volatilidade de preços e de outros fatores sobre o valor futuro das posições. $^{163}$

A margem de manutenção (maintenance margin), por sua vez, representa um valor mínimo que deve ser mantido em garantia das obrigações em aberto. Caso esse parâmetro seja aumentado, as partes serão notificadas para prestar garantias adicionais (situação conhecida como "chamada de margem" ou, em inglês, margin call). ${ }^{164}$

\footnotetext{
${ }^{162}$ Cf. NETO, Eduardo Salomão. Direito Bancário. pp. 346-347.

${ }^{163}$ Cf. SETTLEMENTS, Bank for International; COMMISSIONS, International Organization of Securities. Principles for financial markets infrastructures (April 2012, pp. 51-52). Disponível em <http://www.bis.org/publ/cpss101.htm〉. Acesso em 22 set. 2012.
}

${ }^{164}$ Cf. YAZBEK, Otavio. Regulação do Mercado Financeiro e de Capitais. p. 115. 
Já o ajuste diário (variation margin) é exigido frente à exposição atual dos contratantes. Enquanto a margem inicial é calculada a partir de uma estimativa da exposição futura, o ajuste diário é calculado a partir da técnica de marcação a mercado (marking to market), que consiste na reavaliação de posições em aberto, comparando-se o preço originalmente fixado pelas partes e o preço atual no mercado. A partir desse cálculo, o agente ao qual a variação de preço foi prejudicial deverá cobrir suas perdas e, por outro lado, o agente favorecido pela oscilação terá a respectiva quantia creditada a seu favor.

$\mathrm{Na}$ visão do professor Nelson Eizirik, as três espécies de depósito (initial margin, maintenance margin e variation margin) apresentam inequivocadamente a natureza de margem, que garante o cumprimento das obrigações do comitente. ${ }^{165}$

Em sentido oposto, Otavio Yazbek sustenta que os conceitos de margem de garantia e de ajuste diário são distintos no Brasil, embora se confundam no modelo norte-americano. De acordo com esse autor, os contratos futuros negociados em bolsa não tem liquidação apenas no vencimento como ocorre com os contratos a termo, pois são liquidados por diferença diariamente sob a forma dos ajustes diários. Os ajustes diários, portanto, teriam a natureza de pagamento. ${ }^{166}$

\footnotetext{
${ }^{165}$ Cf. EIZIRIK, Nelson. Aspectos jurídicos dos mercados futuros. p. 34. Essa linha reflete a orientação do Direito Norte-Americano, no qual as margens iniciais e os ajustes diários são compreendidos como performance bonds, ou seja, garantias de execução das obrigações (Vide LEÃES, Luiz Gastão Paes de Barros. Liquidação Compulsória de Contratos Futuros. p. 50).

${ }^{166}$ Cf. YAZBEK, Otavio. Regulação do Mercado Financeiro e de Capitais. p. 114. No mesmo sentido, o glossário disponível no site da CFTC prevê as seguintes definições: "Margin: The amount of money or collateral deposited by a customer with his broker, by a broker with a clearing member, or by a clearing member with a clearing organization. The margin is not partial payment on a purchase. Also called Performance Bond. (1) Initial margin is the amount of margin required by the broker when a futures position is opened; (2) Maintenance margin is an amount that must be maintained on deposit at all times. If the equity in a customer's account drops to or below the level of maintenance margin because of adverse price movement, the broker must issue a margin call to restore the customer's equity to the initial level. See Variation Margin. (...)"; e "Variation Margin: Payment made on a daily or intraday basis by a clearing member to the clearing organization based on adverse price movement in positions carried by the clearing member, calculated separately for customer and proprietary positions." (grifos nossos) (CFTC Glossary. Disponível em <http://www.cftc.gov/ConsumerProtection/EducationCenter/ CFTCGlossary/index.htm>. Acesso em 27 out. 2012.)
} 
De acordo com os padrões internacionais atinentes à matéria, as contrapartes centrais devem realizar a marcação a mercado e o respectivo ajuste diário ao menos diariamente, além de possuir poderes e capacidade operacional para efetuar chamadas de margem e pagamentos intradia, tanto previamente agendados quanto extraordinários. ${ }^{167} \mathrm{Em}$ atendimento a esses parâmetros, destcamos que o Manual de Procedimentos Operacionais da Câmara de Derivativos: Segmento BM\&F trata diretamente do monitoramento de risco intradiário, nos seguintes termos:

\section{“3.3. Monitoramento de Risco Intradiário}

A Câmara acompanha continuamente sua exposição ao risco de crédito dos participantes por meio do monitoramento do risco intradiário, que lhe permite realizar antecipações de chamada de margem, ao longo do dia, isto é, efetuar chamada de margem em $\mathrm{D}+0$, reduzindo seu grau de exposição a risco." (grifos originais) ${ }^{168}$

Dessa maneira, os riscos de crédito e liquidez suportados pela contraparte central são constantemente monitorados e, em última hipótese, estão restritos ao período máximo de um dia.

\subsection{Ajuste Diário e Encerramento de Posições}

Nas bolsas de derivativos, pode-se encerrar uma operação de compra ou venda por meio de operação em sentido contrário, desde que na mesma quantidade e com o mesmo vencimento. Quem está “comprado" em 10 contratos com vencimento em 2012, pode encerrar sua posição "vendendo" 10 contratos para a mesma data, e vice-versa.

\footnotetext{
${ }^{167}$ Cf. SETTLEMENTS, Bank for International; COMMISSIONS, International Organization of Securities. Principles for financial markets infrastructures (April 2012, p. 50). Disponível em <http://www.bis.org/publ/cpss101.htm>. Acesso em 22 set. 2012. Note-se, contudo, que este estudo internacional entende haver somente duas espécies de margens: initial margin e variation margin.

${ }^{168}$ Item 3.3 constante no Capítulo V do Manual de Procedimentos Operacionais da Câmara de Derivativos: Segmento BM\&F. Disponível em <http://www.bmfbovespa.com.br/ptbr/regulacao/regulamentos-e-normas/procedimentos-operacionais/derivativos.aspx?Idioma=pt-br $>$. Acesso em 21 out. 2012.
} 
Esse mecanismo de encerramento de posições somente se opera em razão dos seguintes fatores: (i) ajustes diários, visto que a inexistência de eventuais saldos a pagar ao início de cada pregão facilita a liquidez das posições (ao final de cada dia anterior, todas as posições são “zeradas"); (ii) padronização contratual, o que impede a discussão sobre os melhores termos e condições para se assumir uma nova posição, facilitando a troca de posições; e (iii) natureza registral das posições, o que garante sua total fungibilidade, por meio de lançamentos contábeis. ${ }^{169}$

Segundo o professor Nelson Eizirik, tal mecanismo de encerramento de posições se fundamenta no instituto da cessão contratual. Em suas palavras:

\begin{abstract}
"Juridicamente, estamos diante, de uma cessão de contrato, conforme antes referido. O titular da posição compradora, p. ex., ao realizar uma operação oposta, cede sua posição contratual a outro participante do mercado. Subsiste a posição compradora, porém com novo titular, podendo o contrato ser levado até o seu termo, com todas as suas características. Daí entendermos que não há, no caso, novação posto que não se extingue a obrigação, operando-se apenas a substituição de uma parte." (grifos originais) ${ }^{170}$
\end{abstract}

No mesmo sentido, o professor Luiz Gastão Paes de Barros Leães ainda destaca que tais cessões são realizadas com liberação do cedente, uma vez que sua eventual responsabilidade, mesmo que em caráter subsidiário, não permitiria a completa transferência das obrigações, inviabilizando a própria dinâmica do mercado. ${ }^{171}$

Já em sentido contrário, o professor Otavio Yazbek questiona a caracterização de cessão contratual no caso, além da própria utilidade da aplicação desse instituto aos mercados futuros, nos seguintes termos:

"A dinâmica dos mercados futuros, porém, demonstra a dificuldade para visualizar uma cessão de contrato. Vale lembrar que as posições detidas pelos

\footnotetext{
${ }^{169}$ Cf. YAZBEK, Otavio. Regulação do Mercado Financeiro e de Capitais. p. 114.

${ }^{170}$ EIZIRIK, Nelson. Aspectos jurídicos dos mercados futuros. p. 32. No mesmo sentido, LEÃES, Luiz Gastão Paes de Barros. Liquidação Compulsória de Contratos Futuros. pp. 47-48).

${ }^{171}$ Cf. LEÃES, Luiz Gastão Paes de Barros. Liquidação Compulsória de Contratos Futuros. p. 48.
} 
participantes são meros registros em seu nome e que, em princípio, eles não se conhecem, sendo que a sua contraparte de fato é o sistema de liquidação da bolsa. Por tal motivo, não há nem mesmo como seguir o trajeto das posições entre os participantes do mercado, sento todas, em princípios, iguais. Por fim, cumpre, ainda, questionar quanto à utilidade da figura da cessão de contrato na análise dos futuros." 172

Sob a perspectiva operacional, é importante destacar que o mecanismo de ajuste diário é tipicamente efetivado a partir de compensação pelo valor líquido multilateral. No caso brasileiro, o Manual de Procedimentos Operacionais da Câmara de Derivativos: Segmento BM\&F aborda diretamente essa técnica de compensação e liquidação:

\section{"1. Compensação e Liquidação Multilateral}

A Câmara atua como contraparte, perante os Membros de Compensação, para fins de liquidação das operações registradas em seus sistemas, cursadas nos Mercados de Bolsa e no Mercado de Balcão na modalidade com garantia. As obrigações oriundas de tais operações são liquidadas por meio do serviço de Liquidação Multilateral Diferida Líquida, denominada simplesmente Liquidação Multilateral." (grifos originais) ${ }^{173}$

\subsection{Colateralização de Derivativos de Balcão}

A crise de 2008 revelou uma série de fragilidades nos mercados financeiros internacionais e uma das principais é a elevada exposição de agentes econômicos nos mercados de derivativos de balcão. Tais mercados decorrem de negociações diretas entre agentes e resultam em contratos totalmente customizados. A complexidade de sua estrutura contratual e mecanismo de cálculo de preço, por sua vez, dificulta a centralização desses contratos em sistemas de compensação e liquidação e, consequentemente, seu monitoramento.

Nesse cenário nada transparente, os agentes podiam assumir posições altamente alavancadas sem a exigência de margens ou outros mecanismos

\footnotetext{
${ }^{172}$ YAZBEK, Otavio. Regulação do Mercado Financeiro e de Capitais. p. 114.

${ }^{173}$ Capítulo IV do Manual de Procedimentos Operacionais da Câmara de Derivativos: Segmento BM\&F. Disponível em $<$ http://www.bmfbovespa.com.br/pt-br/regulacao/regulamentos-enormas/procedimentos-operacionais/derivativos.aspx?Idioma=pt-br>. Acesso em 21 out. 2012.
} 
de proteção, o que ainda potencializava sua exposição. Um dos casos mais emblemáticos foi protagonizado pelo American Internacional Group (AIG), o qual detinha, no final de junho de 2008, uma exposição notional a risco de crédito de US $\$ 446$ bilhões em credit default swaps. ${ }^{174}$

Como resultado, os prejuízos individuais e coletivos foram devastadores, gerando uma série de reflexões sobre a melhor maneira de regular os derivativos de balcão. Uma das principais diretrizes internacionais foi estabelecida pela Declaração de Toronto de junho de 2010, emitida pela Cúpula do G-20:

\footnotetext{
"We reaffirm our commitment to trade all standardized OTC derivatives contracts on exchanges or electronic trading platforms, where appropriate, and clear through central counterparties (CCPs) by end-2012 at the latest." (grifos nossos) $)^{175}$
}

A submissão de derivativos de balcão às contrapartes centrais se relaciona diretamente ao fenômeno conhecido como "colateralização" (collateralization), largamente difundido nos mercados de derivativos para se referir ao gerenciamento de garantias (collateral), sob a forma de margens, em vista da exposição dos agentes.

No Brasil, a imensa maioria dos derivativos já estava registrada em prestadores de serviços de compensação e liquidação, vindo a Lei $n^{0}$ 12.543/11 apenas cristalizar a necessidade de registro, ao alterar a Lei $\mathrm{n}^{\mathrm{o}}$ 6.385/76 para prever que o registro de derivativos em Clearings Houses é condição de validade dessas operações. Nos termos da expressa dicção legal:

${ }^{174}$ CECCHETTI, Stephen G.; GYNTELBERG, Jacob; HOLLANDERS, Marc. Central counterparties for over-the-counter derivatives. In: SETTLEMENTS, Bank for. BIS Quarterly Review (September 2009, p. 45). Disponível em SSRN: <http://papers.ssrn.com/sol3/papers.cfm? abstract id=1472960>. Acesso em 25 out. 2012.

175 Trecho constante no Item 25 da Declaração de Toronto de junho de 2010, emitida pela Cúpula do G-20. Disponível em <http://www.canadainternational.gc.ca/g20/summitsommet/2010/toronto-declaration-toronto.aspx?lang=eng\&view=d $>$. Acesso em 25 out. 2012. 
Art. $2^{\circ}$ da Lei $n^{\circ} 6.385 / 76$ :

" $4^{\circ}$ - É condicão de validade dos contratos derivativos, de que tratam os incisos VII e VIII do caput, celebrados a partir da entrada em vigor da Medida Provisória $\mathrm{n}^{\circ} 539$, de 26 de julho de 2011, o registro em câmaras ou prestadores de serviço de compensação, de liquidação e de registro autorizados pelo Banco Central do Brasil ou pela Comissão de Valores Mobiliários.” (grifos nossos)

Dessa forma, a legislação brasileira vinculou efetivamente todos os derivativos a sistemas de proteções e salvaguardas, contribuindo diretamente para a segurança nessas operações e a própria higidez do sistema financeiro nacional.

\section{Liquidação Compulsória}

As contrapartes centrais devem adotar mecanismos adequados e bem definidos para gerenciar o inadimplemento, em especial, permitindo uma ação rápida para conter pressões de perda e liquidez, e garantir que a contraparte central continue solvente. ${ }^{176}$

Um dos principais mecanismos destinados a esse gerenciamento é a capacidade da contraparte central liquidar compulsoriamente as posições detidas pelos participantes dos mercados de derivativos, diante de casos de inadimplemento, desrespeito a limites operacionais ou situações emergenciais de mercado. Entretanto, como veremos a seguir, esse poder deve ser analisado com ressalvas, sob pena de uma interferência indevida nas relações entre particulares.

O professor Luiz Gastão Paes de Barros Leães dedicou-se ao tema em parecer publicado no ano de 1992, tecendo valiosas considerações. Um ponto importante destacado pelo autor é o fato de que as regras que outorgam o poder de liquidação compulsória se inserem no contexto da

\footnotetext{
${ }^{176}$ Nesse sentido, vide o Princípio 13 do estudo Principles for financial markets infrastructures, elaborado pelo Bank for Intenational Settlements, em conjunto com a International Organization of Securities Commissions (SETTLEMENTS, Bank for International; COMMISSIONS, International Organization of Securities. Principles for financial markets infrastructures (April 2012, p. 78). Disponível em <http://www.bis.org/publ/cpss101.htm〉. Acesso em 22 set. 2012).
} 
autorregulação, complementando as normas previstas nos contratos-padrão. Assim, seria possível identificar uma hierarquização das normas provenientes do exercício da autonomia privada. Em suas próprias palavras:

"Há, assim, na espécie, uma graduação escalonada de preceitos convencionais, que vão dos contratos-padrão, passando pelos regimentos disciplinadores das operações até o estatuto da Bolsa: todos eles consubstanciam a lex privata dos participantes do mercado" (grifos originais) ${ }^{177}$

Diante desse cenário, o autor conclui que o poder autorregulador só poderá interferir nos negócios celebrados por particulares na exata medida das hipóteses existentes, prevalecendo, no caso, uma espécie de legalidade, sob pena de vulnerar-se a irretratabilidade e a intangibilidade dos contratos. A interessante passagem merece transcrição integral:

"Daí que não pode o poder auto-regulador das Bolsas de Mercadorias interferir nas relações privadas além ou aquém das precisas hipóteses em que os partícipes do mercado, no livre exercício da autonomia privada, atribuíram a essas entidades. Prevalece, aí, um idêntico princípio de legalidade: dentro dos limites da lei, as partes têm a faculdade de fixar livremente o conteúdo de seus negócios; mas, uma vez cristalizada a vontade negocial, nenhuma das partes pode alterá-la ou desfazê-la ao seu arbítrio, pela vontade escoteira, a não ser que resulte de mútuo consenso. Trata-se dos princípios da irretratabilidade e da intangibilidade dos contratos, que prevalece com igual plenitude nessa série de comandos encadeados e sobrepostos em que se estrutura o sistema normativo das Bolsas de Mercadorias, pois esse sistema é, como vimos, de matriz consensual e consuetudinária. A infração a esses princípios determinará a ilicitude dos atos praticados." (grifos originais) ${ }^{178}$

Na mesma linha, manifesta-se o professor Nelson Eizirik:

“A liquidação compulsória de posições constitui inequivocadamente uma intromissão no acordo de vontades firmado entre investidores, impedindo-os de cumprir o que foi livremente pactuado. Daí decorre que, dado o caráter excepcional das regras que permitem a liquidação compulsória de posições, devem ser elas sempre e necessariamente interpretadas restritivamente." (grifos nossos) ${ }^{179}$

\footnotetext{
${ }^{177}$ LEÃES, Luiz Gastão Paes de Barros. Liquidação Compulsória de Contratos Futuros. p.52.

${ }^{178}$ Ibid., p.52.

${ }^{179}$ EIZIRIK, Nelson. Aspectos jurídicos dos mercados futuros. p. 33.
} 
Nossos tribunais, por sua vez, também já sinalizaram a necessidade de cautela quando da utilização da liquidação compulsória. Por exemplo, em um interessante julgado do ano de 1993, a Oitava Câmara Civil do Tribunal de Justiça do Estado de São Paulo decidiu, por maioria, responsabilizar a Bolsa Mercantil \& de Futuros por "atuação arbitrária e precipitada" ao liquidar antecipadamente contratos a futuro de IBOVESPA detidos pela BRASCAN Administração e Investimentos Ltda. e outros agentes que atuavam como hedgers, frente aos tumultos gerados pela atuação do investidor Naji Nahas. Aliás, o voto vencedor é categórico ao afirmar a prejudicialidade da posição adotada pela Bolsa:

"A entender o poder discricionário como quer a ré, era preciso que o investidor mais cauteloso buscasse alguma operação à semelhança do hedging, para se garantir não apenas dos azares do mercado, mas também da atuação arbitrária da própria Bolsa." (grifos originais) ${ }^{180}$

Na mesma linha, é a decisão citada pelo professor Nelson Eizirik, que estabelece, indiretamente, a necessidade de notificação do comitente para prestar margem adicional, anteriormente a liquidação da posição em aberto. Vejamos:

\begin{abstract}
"Cabe observar, porém, que nossos tribunais têm oposto restrições à utilização de cláusulas contratuais de tal natureza [i.e. que autorizem o corretor a liquidar a posição do investidor inadimplente, utilizando o produto da venda para atender à necessidade de margem], notadamente quando facultam à Corretora, independentemente de notificação, liquidar compulsoriamente a posição do cliente inadimplente. Nesse sentido, decidiu-se que: 'A cláusula . . . no sentido de autorizar a Corretora a proceder à liquidação sem aviso prévio é leonina, potestativa e ineficaz, porque deixa a seu critério desfazer, sem qualquer notícia ao investidor, a própria finalidade da operação, ensejando-lhe massacrar, a seu critério, o direito do comitente, o que não pode ser admitido como obra de bom senso, como há de ser a de julgador' (Ap. cível 35.994, decidida em 23.4.85, pela 8. ${ }^{\text {a }}$ C. Cível do TJRJ)."
\end{abstract}

Ora, as corretoras atuam na condição de mandatárias de seus comitentes, não estando obrigadas a financiar a exposição desses agentes ou

\footnotetext{
${ }^{180}$ TJSP, Embargos Infringentes $n^{\circ}$ 137.293-1, Rel. José Osório, São Paulo, 20 de outubro de 1993.

${ }^{181}$ EIZIRIK, Nelson. Aspectos jurídicos dos mercados futuros. pp. 32-33.
} 
sequer executar suas ordens quando eles não houverem prestado tempestivamente a margem devida. ${ }^{182}$ Contudo, se manifestarem concordância em realizar operações a descoberto, não poderão surpreender o comitente no futuro, liquidando compulsoriamente sua posição frente a aumentos de exposição, sem as respectivas garantias. Nesse sentido, foi a posição adotada pela Quarta Câmara Civil do Tribunal de Justiça de São Paulo, em acórdão unânime, tratando da venda de opções a descoberto. Vejamos uma passagem desta decisão:

\begin{abstract}
"O que não é admissível é que a corretora, uma profissional do ramo e, portanto conhecedora da engrenagem operacional da Bolsa de Valores, aceite a incumbência de negociar as opções e surpreenda o comitente, contrariando as suas instruções e vindo, depois, justificar-se com a alegação de falta de garantias que ela própria tinha, por dever de ofício, obrigação de ter exigido em tempo oportuno, para poder operar pelo comitente no mercado a descoberto (artigo $4^{\circ}$ da Instrução [CVM] no 14)."
\end{abstract}

Embora não se tenha notícia de julgados recentes acerca do tema, uma linha de compreensão pode ser identificada a partir das manifestações doutrinárias e dos precedentes acima: a liquidação compulsória é um mecanismo necessário e eficaz na gestão de riscos, mas que deve ser visto como medida de exceção e, nessa qualidade, utilizado com extrema cautela, sob pena de uma intromissão ilegal nas relações privadas, em prejuízo dos comitentes diretamente afetados e do mercado em geral.

Aliás, não é por outro motivo que a CVM estabeleceu, no $\operatorname{art.} 4^{\circ} \mathrm{da}$ Instrução $n^{\circ}$ 283/98, que as entidades autorreguladoras dos mercados de liquidação futura poderão adotar medidas emergenciais não previstas em seus regulamentos, desde que comuniquem previamente a essa autarquia o teor da decisão e sua justificativa.

\footnotetext{
${ }^{182}$ Nesses termos, é a decisão unânime da Oitava Câmara do Primeiro Tribunal de Alçada Civil de São Paulo, proferida em 27 de abril de 1988, nos autos da Apelação Cível nº 379.468-SP (Rel. Roberto Rubens).

${ }^{183}$ Quarta Câmara Civil do Tribunal de Justiça de São Paulo, Apelação Cível no 116.181-1, Rel. Freitas Camargo, São Paulo, 05 de outubro de 1989. Destaque-se que, atualmente, o art. $4^{\circ}$ da Instrução CVM n ${ }^{\circ} 14 / 80$ encontra-se revogado pela Instrução CVM no 283/98, a qual trata das garantias nos seus arts. $7^{\circ}, 8^{\circ}$ e $9^{\circ}$.
} 


\section{Fundos Garantidores e Patrimônio Especial}

As contrapartes centrais também adotam mecanismos de segregação patrimonial com vistas à criação de salvaguardas. Entre as principais estruturas, estão a criação de fundos garantidores e patrimônios especiais.

Os fundos garantidores representam um acervo complementar às garantias prestadas individualmente pelos participantes dos mercados. Seus recursos podem originar-se dos participantes, de forma que as perdas passam a ser socializadas entre agentes solventes (modelo conhecido como "suvivors pay"). Por outro lado, os recursos também podem se originar da própria contraparte central, que transfere parcela de seu patrimônio para o fundo ("third parties pay").

Além disso, a Lei no 10.214/01 prevê expressamente a necessidade de constituição de patrimônio especial pelas câmaras ou prestadoras de serviços de compensação e liquidação que atuem em ambientes sistemicamente importantes. Esse patrimônio destacado servirá exclusivamente para a liquidação dos negócios realizados nos mercados operados por essa entidade, não se sujeitando a qualquer constrição judicial para finalidade diversa. É o que dispõem os arts. $5^{\circ}$ e $6^{\circ}$ do referido diploma legal:

"Art. 5 Sem prejuízo do disposto no $\S 3^{\circ}$ do artigo anterior, as câmaras e os prestadores de serviços de compensação e de liquidação responsáveis por um ou mais ambientes sistemicamente importantes deverão, obedecida a regulamentação baixada pelo Banco Central do Brasil, separar patrimônio especial, formado por bens e direitos necessários a garantir exclusivamente o cumprimento das obrigacões existentes em cada um dos sistemas que estiverem operando.

$\S 1^{\circ}$ Os bens e direitos integrantes do patrimônio especial de que trata o caput, bem como seus frutos e rendimentos, não se comunicarão com o patrimônio geral ou outros patrimônios especiais da mesma câmara ou prestador de serviços de compensação e de liquidação, e nãa poderão ser utilizados para realizar ou garantir o cumprimento de qualquer obrigação assumida pela câmara ou prestador de serviços de compensação e de liquidação em sistema estranho àquele ao qual se vinculam. 
$\S 2^{\circ}$ Os atos de constituição do patrimônio separado, com a respectiva destinação, serão objeto de averbação ou registro, na forma da lei ou do regulamento.

Art. $6^{-}$Os bens e direitos integrantes do patrimônio especial, bem como aqueles oferecidos em garantia pelos participantes, são impenhoráveis, e não poderão ser objeto de arresto, seqüestro, busca e apreensão ou qualquer outro ato de constrição judicial, exceto para o cumprimento das obrigações assumidas pela própria câmara ou prestador de serviços de compensação e de liquidação $\underline{n} \boldsymbol{a}$ qualidade de parte contratante, nos termos do disposto no caput do art. $4^{o}$ desta $\underline{\text { Lei. }}$ [i.e. contraparte central]" (grifos nossos)

Vale destacar, ainda, que a Circular BACEN $\mathrm{n}^{\mathrm{o}}$ 3.057/01 estabeleceu, em seu art. 19, a necessidade de separação de patrimônio especial mínimo de $\mathrm{R} \$ 10.000 .000,00$, constituído exclusivamente por títulos públicos federais, para cada um dos sistemas sistemicamente importantes que as câmaras ou os prestadores de serviços de compensação e liquidação operem.

\section{Contrapartes Centrais nos Mercados Brasileiros de Derivativos}

Atualmente, a Câmara de Derivativos da BM\&FBovespa é a única Clearing House de derivativos no país que atua na condição de contraparte central, embora a CETIP tenha requerido autorização para exercer essa atividade nos mercados de derivativos sob sua administração. O surgimento de novas contrapartes centrais também é impulsionado pela possibilidade de implantação de novas bolsas no mercado brasileiro.

Entretanto, as autoridades brasileiras ainda não se posicionaram sobre a viabilidade da atuação de mais uma contraparte central em nossos mercados. A questão é extremamente atual e, cada vez mais, as referidas autoridades sofrerão pressão para decidir o assunto. A nosso ver, uma solução para a questão poderia se fundamentar nas seguintes considerações.

Em primeiro lugar, os mercados administrados pela BM\&FBovespa (dotados de uma contraparte central) não oferecem os melhores custos de negociação e pós-negociação quando comparados a mercados em que a 
competição foi introduzida, por exemplo, o Australian Securities Exchange - ASX. ${ }^{184}$

Além disso, em se tratando mais especificamente de derivativos, a BM\&FBovespa esteve tradicionalmente associada aos mercados de bolsa, enquanto a CETIP esteve focada nos mercados de balcão. Como sabido, as estruturas contratuais dos derivativos de balcão (ainda que padronizadas, como no caso brasileiro) são dotadas de alta complexidade, especialmente em comparação com os modelos contratuais dos derivativos de bolsa. Então, no cenário atual, os derivativos de balcão mais sofisticados acabam sendo submetidos à CETIP, o que gera: (i) segurança sob o ponto de vista regulatório, visto que as metodologias de cálculo de preços e os mecanismos de gerenciamento de riscos para derivativos complexos já integram sua especialidade; mas, por outro lado, (ii) certa insegurança sob a perspectiva financeira, na medida em que essa entidade não garante as operações cursadas em seus sistemas na qualidade de contraparte central, apesar dos mecanismos de gestão de riscos existentes.

Destaque-se, igualmente, que a existência de mais de uma contraparte central para mercados de derivativos permite a adoção de prática conhecida (e recomendada) internacionalmente como crossmargining, a qual consiste na administração conjunta de margens que seriam exigidas por diferentes contrapartes centrais como em um portfólio único. A eficácia desse mecanismo reside na possibilidade de redução da necessidade agregada de margem, embora demande profunda coordenação entre as contrapartes centrais para administração conjunta de riscos. ${ }^{185}$

\footnotetext{
${ }^{184} \mathrm{Cf}$. OXERA. What would be the costs and benefits of changing the competitive structure of the market for trading and post-trading services in Brazil? (Prepared for Comissão de Valores Mobiliários, June 2012, p. iii). Disponível em <http://www.cvm.gov.br/port/Public/ publ/Oxera\%20report\%2018062012.pdf>. Acesso em 18 de outubro de 2012.

${ }^{185}$ Cf. SETTLEMENTS, Bank for International; COMMISSIONS, International Organization of Securities. Principles for financial markets infrastructures (April 2012, pp. 54-55, 175). Disponível em <http://www.bis.org/publ/cpss101.htm〉. Acesso em 22 de setembro de 2012.
} 
Portanto, entendemos que a introdução de uma nova contraparte central nos mercados brasileiros de derivativos, especialmente caso vinculada aos mercados da CETIP, representaria uma estratégia segura e eficiente para o desenvolvimento do sistema financeiro nacional. Inclusive, porque a CETIP já desempenha papel sistemicamente relevante em nosso país e, assim, a autorização para que atue como contraparte central estaria em linha com a exigência prevista no artigo $4^{\circ}$ da Lei ${ }^{\circ} 10.214 / 01$.

\section{CONCLUSÕES}

Diante da exposição realizada neste estudo, pode-se concluir que o Brasil, atualmente, possui uma sofisticada e confiável estrutura em seu mercado de derivativos. O novo sistema de pagamentos brasileiro recepcionou as principais diretrizes internacionais no que tange à transferência de recursos financeiros e à administração de riscos, notadamente do risco sistêmico, o que permite a existência de contrapartes centrais orientadas pelos mais altos padrões de eficiência e segurança para as operações de derivativos.

Sob a perspectiva legal, observamos um arcabouço jurídico coeso, claro e atualizado, tendo como ponto de partida a Lei $n^{\circ} 10.214 / 01$, a qual é complementada por ampla regulação e autorregulação.

É importante notar, ainda, que a estrutura legal e institucional hoje existente no Brasil não foi implementada às pressas, como uma medida emergencial, mas já está em funcionamento há anos e, certamente, foi um diferencial de nosso sistema financeiro nas crises mais recentes - ainda que elas tenham atingido nossa economia com menor intensidade em comparação com seus locais de origem, como os Estados Unidos e a Europa.

Tal arquitetura, é claro, não está totalmente imune a falhas ou à necessidade de eventuais ajustes e aprimoramentos, sobretudo em razão do vigoroso desenvolvimento dos mercados de derivativos. Contudo, não resta 
dúvida de que está ancorada em princípios que traduzem ampla experiência e aceitação internacional, representando um suporte adequado aos mercados de nosso país. 


\section{REFERÊNCIAS BIBLIOGRÁFICAS}

\section{$\underline{\text { Livros e artigos }}$}

ALMEIDA, Samy Sanches de. Crise dos derivativos: reforma Dodd-Frank e o clearing centralizado. Revista de Direito Mercantil. São Paulo: Malheiros, 2011, vol. 157, pp. 167-185.

ANDIMA, Associação Nacional das Instituições do Mercado Aberto. Sistema de Pagamentos Brasileiro (Relatório Econômico). Rio de Janeiro: ANDIMA, 2002, $159 \mathrm{p}$.

BHALA, Raj. Legal Foundations of Large-Value Transfer Systems. In: SUMMERS, Bruce J. (editor). The Payment System: Design, Management, and Supervision. International Monetary Fund: Washington, D.C., 1994, pp. 53-72.

BERGH, Paul Van den. Operational and Financial Structure of the Payment System. In: SUMMERS, Bruce J. (editor). The Payment System: Design, Management, and Supervision. International Monetary Fund: Washington, D.C., 1994, pp. 29-40.

BERGH, Paul Van den; VEALE, John M. Payment System Risk and Risk Management. In: SUMMERS, Bruce J. (editor). The Payment System: Design, Management, and Supervision. International Monetary Fund: Washington, D.C., 1994, pp. 89-105.

BERNSTEIN, Peter L. Against the gods: The remarkable story of risk. New York: J. Wiley, 1996. 383 p. 
BESSADA, Octavio; BARBEDO, Claudio; ARAÚJO, Gustavo Silva. Mercado de derivativos no Brasil: conceitos, operações e estratégias. $2^{\mathrm{a}}$ Ed. Rio de Janeiro: Record, 2007. 366 p.

BLACK, Henry Campbell, Black's law dictionary. $6^{\text {th }}$ Ed. Minnesota: West Publishing, 1990. 1657 p.

BLOMMSTEIN, Hans J.; SUMMERS, Bruce J. Banking and the Payment System. In: SUMMERS, Bruce J. (editor). The Payment System: Design, Management, and Supervision. International Monetary Fund: Washington, D.C., 1994, pp. 15-28.

BM\&FBOVESPA. Manual de Procedimentos Operacionais da Câmara de Derivativos: Segmento BM\&F. Disponível em <http://www.bmfbovespa. com.br/pt-br/regulacao/regulamentos-e-normas/procedimentos-operacionais /derivativos.aspx?Idioma=pt-br>. Acesso em 21 out. 2012.

BROWN, Claude. How to Recognize a Derivative. International Financial Law Review (May 1995). London: Euromoney Institutional Investors, 1995, p. 28.

CECCHETTI, Stephen G.; GYNTELBERG, Jacob; HOLLANDERS, Marc. Central counterparties for over-the-counter derivatives. In: SETTLEMENTS, Bank for. BIS Quarterly Review (September 2009, pp. 45-58). Disponível em SSRN: <http://papers.ssrn.com/sol3/papers.cfm? abstract $\mathrm{id}=1472960>$. Acesso em 25 out. 2012.

CETIP. Regulamento da CETIP. Disponível em <http://www.cetip.com.br/ informacao tecnica/regulamento e manuais/regulamento/Regulamento_C ETIP.pdf>. Acesso em 07 out. 2012 
CHANCE, Don M. A Brief History of Derivatives. In: CHANCE, Don M. Essays in Derivatives: Risk-Transfer Tools and Topics Made Easy. $2^{\text {nd }}$ Ed. New Jersey: John Wiley \& Sons, 2008, 414 p.

CHEDIAK, Julian Fonseca Peña. A Reforma do Mercado de Valores Mobiliários. In: LOBO, Jorge; KANDIR, Antonio (Coords.). Reforma da Lei das Sociedades Anônimas: inovações e questões controvertidas da Lei 10.303, de 31.10.2001. 2a Ed., Rio de Janeiro: Forense, 2002, pp. 525-551.

COELHO, Fabio Ulhoa. Os derivativos e a desvalorização do Real em 2008. Revista de Direito Bancário e do Mercado de Capitais. São Paulo: Revista dos Tribunais, 2009, vol. 44, pp. 75-89.

COMMISSION, Commodity Futures Trading. History of the CFTC. Disponível em <http://www.cftc.gov/About/HistoryoftheCFTC/index.htm>. Acesso em 08 de abril de 2012

COMMISSION, Commodity Futures Trading. CFTC Glossary. Disponível em < http://www.cftc.gov/ConsumerProtection/EducationCenter/ CFTCGlossary/index.htm>. Acesso em 27 out. 2012.

DEPUTADOS, Câmara dos. Parecer da Comissão Especial destinada a apreciar as emendas do Senado Federal ao Projeto de Lei no 634 de 1975. 311 p. Disponível em <www.camara.gov.br/sileg/integras/303077.doc>. Acesso em 20 de maio de 2012.

DIAS, Gustavo Neto de Carvalho. As caixas de liquidação no âmbito do sistema de pagamentos brasileiro. São Paulo: Faculdade de Direito, Universidade de São Paulo, 2011, 95 p. (Dissertação de Mestrado) Disponível em <http://www.teses.usp.br/teses/disponiveis/2/2132/tde-

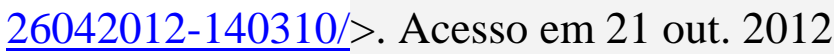


EIZIRIK, Nelson. Aspectos jurídicos dos mercados futuros. Revista de Direito Mercantil. São Paulo: Revista dos Tribunais, 1991, vol. 81, pp. 2235 .

EIZIRIK, Nelson; GAAL, Ariádna B.; PARENTE, Flávia; HENRIQUES, Marcus de Freitas. Mercado de capitais: regime jurídico. Rio de Janeiro: Renovar, 2008, 624 p.

FILHO, Ari Cordeiro. Swaps - aspectos jurídicos. Revista de Direito Bancário e do Mercado de Capitais. São Paulo: Revista dos Tribunais, 2001, vol. 11, p. 68.

FILHO, Arnoldo Wald; ANTUNES, Mariana Tavares; GAENSLY, Marina. Contratos de swap (...). Revista de Direito Bancário e do Mercado de Capitais. São Paulo: Revista dos Tribunais, 2005, vol. 28, pp. 309-320.

FILHO, Luiz Gastão Leães. Derivatives Suitability. Revista de Direito Mercantil. São Paulo: Revista do Tribunais, 1996, vol. 102, pp. 59-71

FILHO, Oscar Barreto. As operações a termo sobre mercadorias ("hedging”). Revista de Direito Mercantil. São Paulo: Revista dos Tribunais, 1976, vol. 29, pp. 11-17.

FILHO, Valdir Carlos Pereira. Clearing Houses: Aspectos Jurídicos Relevantes e seu Papel no Mercado de Capitais e no Sistema de Pagamentos Brasileiro. Revista de Direito Bancário e do Mercado de Capitais. São Paulo: Revista dos Tribunais, 2005, vol. 27, p. 64.

FORGIONI, Paula A. Teoria geral dos contratos empresariais. São Paulo: Revista dos Tribunais, 2010, $271 \mathrm{p}$. 
FRANCO, Gustavo H. B. Você acredita em teoria econômica? O Estado de São Paulo, 09 de novembro de 2001. Disponível em < http://www.econ.pucrio.br/gfranco/a128.htm>. Acesso em 16 de junho de 2012.

FRANTZ, Laura Coradini. Revisão dos contratos: elementos para sua construção dogmática. São Paulo: Saraiva, 2007, 192 p.

GENSLER, Gary. Chairman's Transmittal Letter. In: COMMISSION, Commodity Futures Trading. The FY 2013 President's Budget \& Performance Plan. Disponível em <http://www.cftc.gov/About/ CFTCReports/index.htm>. Acesso em 07 de abril de 2012.

GOLDBERG, Daniel Krepel. A Lei 10.303, de 2001, e a inclusão dos derivativos no rol dos valores mobiliários. Revista de Direito Mercantil. São Paulo: Malheiros, 2003, vol. 129, pp. 73-82.

GOLDSTEIN, Sergio Mychkis. Aspectos jurídicos dos derivativos de crédito no Brasil. Revista de Direito Bancário e do Mercado de Capitais. São Paulo: Revista dos Tribunais: 2004, vol. 25, p. 63.

GROUP, CME. From Water Street to the World. CME Group Magazine, Summer 2007. Disponível em <http://www.cmegroup.com/ company/history/magazine/Summer2007/FromWaterStreetToTheWorld.ht $\underline{\mathrm{ml}}$. Acesso em 08 de abril de 2012.

GROUP, CME. Life in the Fast Lane. Disponível em $<$ http://www.cmegroup.com/company/history/magazine/vol7-issue2/life-inthe-fast-lane.html>. Acesso em 07 de abril de 2012. 
GROUP, CME. Spirit of Innovation. Disponível em < http://www.cmegroup .com/company/history/timeline-of-achievements.html>. Acesso em $07 \mathrm{de}$ abril de 2012.

GROUP, CME. The Birth of FX Futures. Disponível em $<$ http://www.cmegroup.com/company/center-for-innovation/files/history_of _FX.pdf>. Acesso em 05 de novembro de 2012.

G-20, Cúpula do. Declaração de Toronto de junho de 2010. Disponível em <http://www.canadainternational.gc.ca/g20/summit-sommet/2010/torontodeclaration-toronto.aspx?lang=eng\&view=d> . Acesso em 25 out. 2012.

HORII, Akinari; SUMMERS, Bruce J. Large-Value Transfer Systems. In: SUMMERS, Bruce J. (editor). The Payment System: Design, Management, and Supervision. International Monetary Fund: Washington, D.C., 1994, pp. 73-88.

HULL, John. Options, futures, and other derivatives. $6^{\text {th }}$ Ed., New Jersey: Prentice Hall, 2006, 789 p.

INSTITUTE, Options. Options: essential concepts and trading strategies. $2^{\text {nd }}$ Ed. Illinois: Irwin Professional Publishing, 1995. $421 \mathrm{p}$.

KOESTER, Axel. Today, Orange County... Businessweek, 18 de dezembro de 1994. Disponível em <http://www.businessweek.com/stories/1994-1218/today-orange-county-dot-dot-dot>. Acesso em 08 de abril de 2012.

LAMY FILHO, Alfredo; BULHÕES PEDREIRA, José Luiz. A lei das S.A.: pressupostos, elaboração, aplicação. Rio de Janeiro: Renovar, 1997, vol. I, 508 p. 
LEÃES, Luiz Gastão Paes de Barros. "Hedging” com futuros de índices representativos de ações. Revista de Direito Mercantil. São Paulo: Malheiros, 2001, vol. 124, pp. 215-232.

LEÃES, Luiz Gastão Paes de Barros. Liquidação Compulsória de Contratos Futuros. Revista dos Tribunais. São Paulo: Revista dos Tribunais, 1992, vol. 675, pp. 44-55.

LOBO, Carlos Augusto da Silveira. Os mercados de futuros. Revista de Direito Mercantil. São Paulo: Malheiros, 2001, vol. 124, pp. 148-151.

LOPES, Alexsandro Broedel. Operações com derivativos: uma introdução multidisciplinar e algumas lições da crise no Brasil. Revista de Direito Mercantil. São Paulo: Malheiros, 2009, vol. 148, pp. 17-26.

MARQUARDT, Jeffrey C. Payment System Policy Issues and Analysis. In: SUMMERS, Bruce J. (editor). The Payment System: Design, Management, and Supervision. International Monetary Fund: Washington, D.C., 1994, pp. $116-144$

MARTINS-COSTA, Judith. Contratos de Derivativos Cambiais. Contratos Aleatórios. Abuso de Direito e Abusividade Contratual. Boa-fé objetiva (Parecer). Revista de Direito Bancário e do Mercado de Capitais. São Paulo: Revista dos Tribunais, 2012, vol. 55, pp. 321-381.

MCDONALD, Robert L., Derivatives markets. $2^{\text {nd }}$ Ed., Boston: Addison Wesley, 2006, 694 p.

MILLER, Merton H. Merton Miller on Derivatives. New York: John Wiley and Sons, 1997, $226 \mathrm{p}$. 
MIRANDA, Pontes de. Tratado de Direito Privado. $3^{a}$ Ed. São Paulo: Revista dos Tribunais, 1984, Parte Especial, Tomo LII, p. 282.

MISHKIN, Frederic S. The economics of money, banking, and financial markets. $7^{\text {th }}$ Ed. Massachusetts: Addison-Wesley, 2004. 679 p.

NETO, Eduardo Salomão. Direito Bancário. $1^{\mathrm{a}}$ Ed. São Paulo: Editora Atlas, 2005. 626 p.

NETO, Eduardo Salomão. Nova Regulamentação do Mercado de Balcão Organizado. Revista de Direito Mercantil. São Paulo: Malheiros, 1998, vol. 109, pp. 102-107.

NUSDEO, Fábio. Curso de Economia: introdução ao direito econômico. $6^{\mathrm{a}}$ Ed. São Paulo: Revista dos Tribunais, 2010. 376 p.

OXERA. What would be the costs and benefits of changing the competitive structure of the market for trading and post-trading services in Brazil? (Prepared for Comissão de Valores Mobiliários, June 2012, 159 p.) Disponível em <http://www.cvm.gov.br/port/Public/publ/Oxera\%20report \%2018062012.pdf>. Acesso em 18 de outubro de 2012.

PAULIN, Luiz Alfredo. Das alterações introduzidas pelo novo código civil no mercado de capitais. Revista de Direito Bancário e do Mercado de Capitais. São Paulo: Revista dos Tribunais, 2003, vol. 21, p. 259.

PEREIRA, Caio Mário da Silva. Instituições de Direito Civil. $21^{\mathrm{a}}$ Ed. Rio de Janeiro: Editora Forense, 2008, vol. II. 472 p.

PINGITZER, Jürgen C.; SUMMERS, Bruce J. Small-Value Transfer Systems. In: SUMMERS, Bruce J. (editor). The Payment System: Design, 
Management, and Supervision. International Monetary Fund: Washington, D.C., 1994, pp. 106-115.

SETTLEMENTS, Bank for International. Delivery versus Payment in Securities Settlement Systems (September 1992, 86 p.) Disponível em < http://www.bis.org/publ/cpss06.htm>. Acesso em 22 de setembro de 2012.

SETTLEMENTS, Bank for International. General guidance for national payment system development (January 2006, 73 p.) Disponível em <http://www.bis.org/publ/cpss70.htm>. Acesso em 22 de setembro de 2012

SETTLEMENTS, Bank for International. Real-Time Gross Settlement Systems (March 1997, 66 p.) Disponível em <http://www.bis.org/publ/cpss22.htm> . Acesso em 22 de setembro de 2012.

SETTLEMENTS, Bank for International. Report of the Committee on Interbank Netting Schemes of the Central Banks of the Group of Ten Countries (November 1990, 39 p.) Disponível em <http://www.bis.org/publ/cpss04.pdf > . Acesso em 20 de outubro de 2012.

SETTLEMENTS, Bank for International; COMMISSIONS, International Organization of Securities. Principles for financial markets infrastructures (April 2012, $182 \quad$ p.) Disponível em $<$ http://www.bis.org/publ/cpss101.htm>. Acesso em 22 de setembro de 2012.

SOUZA, Leandro Alves de. Sistema de pagamentos brasileiro: nova estrutura e seus impactos econômicos. São Paulo: Saraiva, 2001. 86 p.

SUMMERS, Bruce J. The Payment System in a Market Economy. In: SUMMERS, Bruce J. (editor). The Payment System: Design, Management, 
and Supervision. International Monetary Fund: Washington, D.C., 1994, pp. $1-14$.

SQUASSONI, Christian Max Finardi. Riscos operacionais nos mercados de futuros, opções e de swaps na Bolsa de Mercadorias e Futuros - BM\&F. Revista de Direito Mercantil. São Paulo: Malheiros, 2000, vol. 120, pp. 242-249.

SZTAJN, Rachel. Futuros e swaps: uma visão jurídica. São Paulo: Cultural Paulista, 1998, 263 p.

SZTAJN, Rachel. Regulação e o Mercado de Valores Mobiliários. Revista de Direito Mercantil. São Paulo: Malheiros, 2004, vol. 135, pp. 136-147.

SZTAJN, Rachel. Sobre a natureza jurídica das opções negociadas em bolsas. Revista de Direito Mercantil. São Paulo: Malheiros, 1997, vol. 105, pp. 53-69.

TALAVERA, Glauber Moreno. Aspectos Elementares do Hedging. In: WAISBERG, Ivo; e FONTES, Marcos Rolim Fernandes (Coords.). Contratos bancários. pp. 195-206.

TEWELES, Richard Jack; JONES, Frank Joseph. The futures games: who wins? who loses? why? $2^{\text {nd }}$ Ed. New York: McGraw-Hill, 1987. 649 p.

THIRTY, Group of. Global Clearing and Settlement: A Plan of Action. Group of Thirty: Washington, D.C., 2003, 137 p. Disponível em <http://www.group30.org/rpt 12.shtml >. Acesso em 22 set. 2012

THIRTY, Group of. International Insolvencies in the Financial Sector: A Study Group Report. Group of Thirty: Washington, D.C., 1998, 170 p. 
VERÇOSA, Haroldo Malheiros Duclerc. Negócios com opções - a opção flexível. Revista de Direito Mercantil. São Paulo: Malheiros, 1999, vol. 114, pp. 63-67.

WALD, Arnoldo. As corretoras e o financiamento de operações a termo (aspectos jurídicos do problema). Revista de Direito Mercantil. São Paulo: Revista dos Tribunais, 1976, vol. 29, pp. 19-27.

WEBER, Ernst Juerg. A Short History of Derivative Security Markets (49 p.) Disponível em SSRN <http://ssrn.com/abstract=1141689>. Acesso em 07 de abril de 2012.

WUDUNN, Sheryl. Sumitomo Increases Size of Copper-Trade Loss to \$2.6 Billion, New York Times, 20 de setembro de 1996. Disponível em < http://www.nytimes.com/1996/09/20/business/sumitomo-increases-size-of -copper-trade-loss-to-2.6-billion.html? $\mathrm{src}=\mathrm{pm}>$. Acesso em $08 \mathrm{de}$ abril de 2012.

YAZBEK, Otavio. Regulação do Mercado Financeiro e de Capitais. Rio de Janeiro: Elsevier, 2007, 316 p.

YAZBEK, Otavio. O risco de crédito e os novos instrumentos financeiros uma análise funcional. In: WAISBERG, Ivo; e FONTES, Marcos Rolim Fernandes (Coords.). Contratos bancários. São Paulo: Quartier Latin, 2006, pp. 309-337.

$\underline{\text { Jurisprudência Administrativa e Judicial }}$

Processo Administrativo CVM n. ${ }^{\circ}$ RJ 2003/0499 (Certificados de Potencial Adicional de Construção - CEPACs), julgado em 28.08.2003. 
Processo CVM no RJ 2009/6346 (Créditos de Carbono), julgado em 07.07.2009.

STJ, REsp n 936.741 - GO, Rel. Ministro Antonio Carlos Ferreira, Brasília, 3 de novembro de 2011.

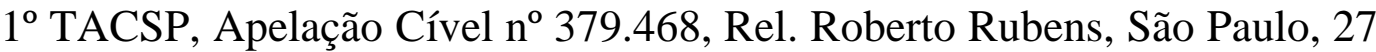
de abril de 1988.

TJSP, AgIn nº 0304899-85.2011.8.26.0000, Rel. Elliot Akel, São Paulo, 17 de abril de 2012 .

TJSP, Apelação Cível nº 116.181-1, Rel. Freitas Camargo, São Paulo, 05 de outubro de 1989.

TJSP, Embargos Infringentes n 137.293-1, Rel. José Osório, São Paulo, 20 de outubro de 1993.

U.S. Supreme Court: Christie Grain \& Stock Co. v. Chicago Board of Trade, 1905, 198 U.S., 236 (vide o artigo de Oscar Barreto Filho). 